PAULO HENRIQUE BROSSI SABIA

\title{
PROJETO E CONSTRUÇÃO DE UM EQUIPAMENTO BIAXIAL PARA A CARACTERIZAÇÃO MECÂNICA DE TECIDOS BIOLÓGICOS TUBULARES
}

São Paulo 
PAULO HENRIQUE BROSSI SABIA

PROJETO E CONSTRUÇÃO DE UM EQUIPAMENTO BIAXIAL PARA A CARACTERIZAÇÃO MECÂNICA DE TECIDOS BIOLÓGICOS TUBULARES

São Paulo 


\section{PAULO HENRIQUE BROSSI SABIA}

\section{PROJETO E CONSTRUÇÃO DE UM EQUIPAMENTO BIAXIAL PARA A CARACTERIZAÇÃO MECÂNICA DE TECIDOS BIOLÓGICOS TUBULARES}

Dissertação apresentada à Escola

Politécnica da Universidade de São

Paulo para obtenção do título de Mestre em Ciências

Área de Concentração: Engenharia de Controle e Automação Mecânica

Orientador: Professor Dr. Raul Gonzalez Lima

São Paulo 
CATALOGAÇÃO-NA-PUBLICAÇÃO

Sabia, Paulo Henrique Brossi

Projeto e construção de um equipamento biaxial para a caracterização mecânica de tecidos biológicos tubulares / P.H.B. Sabia. - versão corr. - São Paulo, 2015.

$99 \mathrm{p}$.

Dissertação (Mestrado) - Escola Politécnica da Universidade de São Paulo. Departamento de Engenharia Mecânica.

1. Aorta abdominal 2. Aneurisma aórtico 3. Tecidos (Anatomia) 4. Ensaios mecânicos I. Universidade de São Paulo. Escola Politécnica. Departamento de Engenharia Mecânica II.t. 


\section{Agradecimentos}

Primeiramente, agradeço aos meus pais, que me apoiaram durante todo o percurso e me ajudaram a vencer esse obstáculo e tantos outros, desde quando nem me lembro.

Agradeço a valiosa colaboração dos meus colegas de laboratório, em especial ao Erick Dario León Bueno de Camargo e ao Fernando Silva de Moura. Outras pessoas importantes durante a realização desta dissertação foram: Olavo Luppi Silva, Talles Batista Rattis Santos, André Luis dos Santos, Rudolf Hellmuth, Luís Henrique Camargo Quiroz, Michelle Marie Mellenthin, Isadora de Oliveira Hoffmann, Ana Isabel Arroyave Guzmán e Ana Carolina Carneiro de Freitas, amigos que levarei para fora do ambiente de trabalho. Agradeço aos meus amigos Rafael Salles e Ovandir Bazan, que se mostraram sempre disponíveis para me dar apoio moral quando precisei.

Obrigado ao Dr. José Augusto Tavares Monteiro e ao Dr. Erasmo Simão da Silva, por terem disponibilizado informações essenciais para o dimensionamento do equipamento desenvolvido, além de terem me mostrado um dos experimentos realizados na Faculdade de Medicina da Universidade de São Paulo, o que me deu maior motivação durante esta longa jornada. Ao Dr. Paulo Rodrigues, agradeço pela motivação adicional, e ao Dr. Harki Tanaka, agradeço por ter me apresentado ao meu orientador, e por ter sido aberto para compartilhar de seu trabalho, quando lhe apresentei a minha necessidade.

Meu respeito e admiração ao meu orientador, Raul Gonzalez Lima, a quem agradeço por toda a atenção e ajuda no trabalho desenvolvido e em outros aspectos da minha vida. Com ele, aprendi muitos conceitos aplicados no desenvolvimento da presente dissertação, mas mais importante que isso foi o aprendizado sobre interdisciplinaridade e sobre os aspectos humanos envolvidos no meu projeto e fora dele. Aprendi a usar conceitos de lógica e de engenharia em vários outros campos do conhecimento, até mesmo nas relações humanas. Ele me ensinou o valor do silêncio, aplicações impressionantes de alteridade e muito sobre mim mesmo, mesmo sem me conhecer há tanto tempo. Mais que um trabalho, ganhei um bom amigo para a vida.

Muito importante foi o financiamento do projeto, através do processo 308827/2012-0. 


\section{Dedicatória}

Dedico este trabalho aos meus pais, que sempre se sacrificaram para que eu tivesse acesso a uma boa educação, colocando-me, muitas vezes, à frente de suas próprias necessidades e interesses pessoais, e ao meu tio José Sabia, que faleceu em decorrência da ruptura de um aneurisma de aorta abdominal. 


\section{Epígrafe}

"Nunca devemos envergonharmo-nos das nossas próprias lágrimas."

Charles Dickens

“Desejo que nossos sonhos de consumo não nos consumam! Que nosso amor ao poder não nos torne insensíveis ao poder do amor. Que aprendamos a dar valor às pequenas coisas que verdadeiramente dão sentido à vida, e nos desapeguemos daquelas que insistem em nos convencer de que são essenciais."

Hermes Fernandes

“No passado, penso logo existo.

No presente, nem penso logo consumo.

No futuro penso, por quê?"

Anita Prado 


\section{Resumo}

Com a evolução da Medicina e o consequente envelhecimento da população, o aneurisma de aorta abdominal (AAA) se tornou uma doença cada vez mais presente, sobretudo em homens. A falta de conhecimento detalhado do comportamento mecânico do tecido aórtico abdominal é o principal gargalo no refinamento do critério para a recomendação de cirurgia corretiva, resultando, ainda hoje, no óbito decorrente da ruptura desses aneurismas. O entendimento do comportamento mecânico desse tecido permitirá o refinamento do critério atual, salvando mais vidas. Esse entendimento pode ser obtido através da Mecânica do Contínuo, utilizando dados experimentais de ensaios mecânicos para avaliar e descrever o comportamento do material. Para que isso ocorra, é necessário que o teste seja feito em dois eixos independentes. No presente trabalho, foram escolhidos os eixos longitudinal e circunferencial para a realização de testes mecânicos, levando em consideração aspectos de metodologias já utilizadas, seus pontos fortes e deficiências. São apresentados o projeto, a construção e e a calibração de um equipamento para ensaios biaxiais de tecidos biológicos tubulares, extraídos de cadáveres, e testados até a ruptura, com a possibilidade de realização de ensaios de pré-condicionamento. Tubos de látex foram utilizados na calibração do equipamento, de cuja utilização é esperada grande contribuição na ampliação do conhecimento da probabilidade de ruptura de AAAs e em uma melhor compreensão do comportamento do tecido da uretra peniana.

Palavras-chave: Máquina de ensaios, teste biaxial, tecidos biológicos, aorta abdominal, aneurisma de aorta abdominal, caracterização mecânica. 


\begin{abstract}
The evolution of Medicine has enabled humans to live longer. With that, the incidence of abdominal aortic aneurysms (AAAs) has grown, especially among males. The lack of detailed knowledge on the mechanical behavior of the abdominal aortic tissue is the main bottleneck in the improvement of the criterion for recommending corrective surgery. Therefore, many patients still die from the rupture of those aneurysms. Better understanding of the tissue's mechanical behavior will allow the refinement of today's criterion, thus saving more lives. This understanding can be obtained from Continuum Mechanics, using mechanical test experimental data to evaluate and describe the behavior of the material. The data has to come from tests performed in two independet axes. This Master's thesis presents the project, manufacturing and calibration of an apparatus for the test of cylindrical biological tissues in two directions, longitudinal and circumferential. Aspects of pre-existent tests and methods and their positive and negative sides were taken into account. The specimens will come from cadavers, and it will be possible to pre-condition them, as well as to test them to the rupture. Latex tubes were used in the calibration of the apparatus, whose utilization is expected to improve the knowledge on AAA rupture probability, as well as to improve the comprehension of the penile urethral tissue's behavior.
\end{abstract}

Keywords: Testing machine, biaxial test, biological tissues, abdominal aorta, abdominal aortic aneurysm, mechanical characterization. 


\section{Sumário}

\begin{tabular}{ll}
\hline Lista de Figuras & 11
\end{tabular}

\begin{tabular}{ll}
\hline Lista de Tabelas & 14
\end{tabular}

Lista de abreviaturas e símbolos . . . . . . . . . . . . . . . . . . . . . . . 15

\begin{tabular}{lll}
\hline & Introdução & 17
\end{tabular}

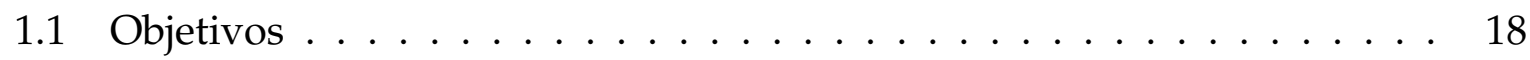

$\begin{array}{lll}2 & \text { Revisão Bibliográfica } & 19\end{array}$

2.1 O Sistema Circulatório . . . . . . . . . . . . . . . . . . . . . . . . . . . . . 19

2.2 Aneurismas . . . . . . . . . . . . . . . . . . . . . 21

2.3 Vasos de Pressão . . . . . . . . . . . . . . . . . . . . 25

2.4 Literatura de metodologias . . . . . . . . . . . . . 27

2.4 .1 Disponíveis . . . . . . . . . . . . . . . . . . 28

2.4 .2 FMUSP . . . . . . . . . . . . . . . . . . . 31

3 Metodologia Empregada 34

3.1 Estimação de dados não encontrados na bibliografia . . . . . . . . . . . . 34

3.2 Descrição do equipamento de ensaio biaxial . . . . . . . . . . . . . . 40

3.3 Projeto do equipamento biaxial . . . . . . . . . . . . . . . . 41

3.4 Construção do equipamento biaxial . . . . . . . . . . . . . . . 41

3.5 Teste e calibração do equipamento . . . . . . . . . . . . . . . . . . 41

\begin{tabular}{|lll}
\hline 4 & Resultados e discussão & 43
\end{tabular}

4.1 Estimação dos dados não encontrados na bibliografia . . . . . . . . . . . 43

4.2 Descrição do equipamento biaxial . . . . . . . . . . . . . . 53

4.3 Projeto e construção do equipamento biaxial . . . . . . . . . . . . . . . 54 
4.3 .1 Garras $\ldots \ldots \ldots \ldots \ldots \ldots \ldots \ldots \ldots \ldots$

4.3 .2 Estrutura em $\mathrm{U} \ldots \ldots \ldots \ldots \ldots \ldots \ldots$

4.3 .3 Cuba . . . . . . . . . . . . . . . . . . . . . . . 64

4.3 .4 Mecanismo de tração longitudinal . . . . . . . . . . . . . . 67

4.3 .5 Mecanismo de insuflamento . . . . . . . . . . . . . . 71

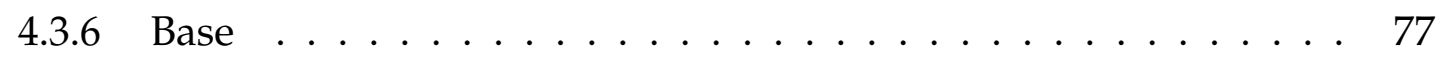

4.3 .7 Controle e aquisição de dados $\ldots \ldots \ldots \ldots$. . . . . . 80

4.4 Teste e calibração do equipamento . . . . . . . . . . . . . . . 83

\begin{tabular}{lll}
\hline 5 Conclusão & 95
\end{tabular}

\begin{tabular}{ll}
\hline Referências Bibliográficas & 96
\end{tabular} 


\section{Lista de Figuras}

2.1 Seção transversa da artéria femoral . . . . . . . . . . . . . . . . . . . 21

2.2 Diâmetro aórtico vs pressão arterial em homens . . . . . . . . . . . . . 22

2.3 Diâmetro aórtico vs pressão arterial em mulheres . . . . . . . . . . . . 23

2.4 Aorta aneurismática . . . . . . . . . . . . . . . 25

2.5 Tensões de Von Mises no modelo de vaso de pressão . . . . . . . . . . . 26

2.6 Seção transversa de estrutura tubular $\ldots \ldots$. . . . . . . . . . . . . 27

2.7 Máquina de teste biaxial cilíndrico . . . . . . . . . . . . . . . . . . . 29

2.8 Teste biaxial plano de tecido aórtico suíno $\ldots \ldots$. . . . . . . . . . 30

2.9 Teste biaxial do tipo bolha de uma membrana elastomérica . . . . . . . . 31

2.10 Máquina de testes e garras usadas no HCFMUSP . . . . . . . . . . . . . 32

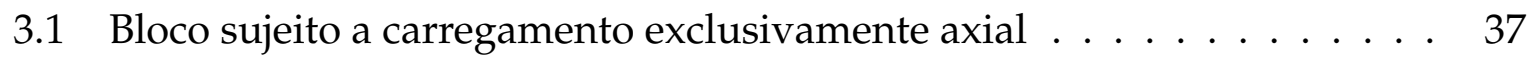

3.2 Influência do sexo e da idade no aumento do diâmetro aórtico . . . . . . 40

3.3 Diagrama de coordenadas no espécime $\ldots \ldots \ldots$. . . . . . . . 41

4.1 Vistas do coração humano, veias cavas superior e inferior . . . . . . . . . 44

4.2 Safena magna . . . . . . . . . . . . . . . . . . . . . 44

4.3 Uretra masculina . . . . . . . . . . . . . . . . . . . . . . . . 46

4.4 Esôfago humano $\ldots \ldots \ldots \ldots \ldots \ldots$. . . . . . . . . . . 47

4.5 Intestino delgado humano . . . . . . . . . . . . . . . . 47

4.6 Colo transverso do intestino grosso humano . . . . . . . . . . . . . . 48

4.7 Dispersão, volumes inicial e máximo vs pressão máxima . . . . . . . . . 52

4.8 Dispersão, elongação máxima vs força máxima . . . . . . . . . . . . . . 53

4.9 Garras para a fixação de espécimes de diâmetro inicial $20 \mathrm{~mm}$. . . . . . 56

4.10 Localização mais comum de AAAs . . . . . . . . . . . . . . . . . . 57

4.11 Adaptação para a fixação de AAAs ao equipamento . . . . . . . . . . . . 57 
4.12 Projeto da estrutura em $\mathrm{U} \ldots \ldots \ldots \ldots$

4.13 Perfil da seção transversal . . . . . . . . . . . . . . . . . . . 59

4.14 Medidas relevantes da estrutura em U para o cálculo da solda . . . . . . 59

4.15 Cálculo da solda da estrutura em U . . . . . . . . . . . . . . . . . . . 60

4.16 Estrutura entre a mesa linear e a célula de carga. . . . . . . . . . . . 62

4.17 Foto da estrutura entre a mesa linear e a célula de carga . . . . . . . . . . 63

4.18 Foto da estrutura em $\mathrm{U} \ldots \ldots$. . . . . . . . . . . . . . . 63

4.19 Projeto da cuba de ensaios $\ldots \ldots \ldots \ldots$. . . . . . . . . . 65

4.20 Foto da cuba de ensaios . . . . . . . . . . . . . 65

4.21 Chapa de aço para a fixação da garra da esquerda . . . . . . . . . . . 66

4.22 Tensões e deformações na chapa à esquerda da cuba de ensaios . . . . . 67

4.23 Foto da célula de carga . . . . . . . . . . . . . . . . . 68

4.24 Mesa linear . . . . . . . . . . . . . . . . . . . . . 68

4.25 Fotos do redutor e do servomotor . . . . . . . . . . . . . . . . . 69

4.26 Foto do servodrive . . . . . . . . . . . . . . . . . 69

4.27 Vista de conjunto das partes relevantes ao ensaio de tração . . . . . . . . 70

4.28 Vista frontal do equipamento . . . . . . . . . . . . . . . . 70

4.29 Esquema elétrico, alimentação da célula de carga e INA126 . . . . . . . 71

4.30 Mecanismo para o insuflamento do espécime . . . . . . . . . . . . 72

4.31 Mecanismo de insuflamento . . . . . . . . . . . . . . . . . 72

4.32 Fotos do compressor de ar e da válvula proporcional . . . . . . . . . 73

4.33 Tanque para o armazenamento de solução fisiológica . . . . . . . . . . . 74

4.34 Tampos do vaso de pressão criado . . . . . . . . . . . . . . . . . 75

4.35 Foto do transdutor de pressão . . . . . . . . . . . . . . . . . 76

4.36 Projeto da base . . . . . . . . . . . . . . . . . 78

4.37 Perfis usados na confecção da base . . . . . . . . . . . . . 78

4.38 Força atuante sobre o perfil mais largo . . . . . . . . . . . . . . . . 79

4.39 Força atuante sobre o perfil mais estreito . . . . . . . . . . . . . . . 79

4.40 Foto da placa de aquisição . . . . . . . . . . . . . . . . . 80

4.41 Sinais para os ensaios de pré-condicionamento uniaxiais . . . . . . . 81

4.42 Sinais mandados para os ensaios de ruptura. . . . . . . . . . . . . 82

4.43 Gráfico para o cálculo da precisão das medidas de pressão . . . . . . . . 84 
4.44 Resultado do pré-condicionamento do teste uniaxial de tração . . . . . . 85

4.45 Fotos de diferentes instantes do mesmo ensaio de tração . . . . . . . . . 85

4.46 Gráfico para a conversão das medidas coletadas em V para gf . . . . . . 86

4.47 Gráfico para o cálculo da precisão da força aquisitada . . . . . . . . . . . 87

4.48 Resultado do teste uniaxial de insuflamento entre 120 e $190 \mathrm{kPa}$. . . . . 88

4.49 Resultado do teste uniaxial de insuflamento entre 120 e $150 \mathrm{kPa}$. . . . . 89

4.50 Resultado do teste uniaxial de insuflamento entre 120 e $140 \mathrm{kPa}$. . . . . 89

4.51 Resultado com 1 ciclo de pré-condicionamento uniaxial, patamares . . . 90

4.52 Efeito da pressão sobre a força de tração sobre a estrutura em U. . . . . . 91

4.53 Resultado do ensaio biaxial . . . . . . . . . . . . . . . . . . . . . 92

4.54 Fotos de diferentes instantes de ensaio biaxial mal sucedido . . . . . . . 93

4.55 Fotos de diferentes instantes de ensaio biaxial bem sucedido . . . . . . . 94 


\section{Lista de Tabelas}

4.1 Parâmetros para testes de diferentes órgãos geometricamente convexos.

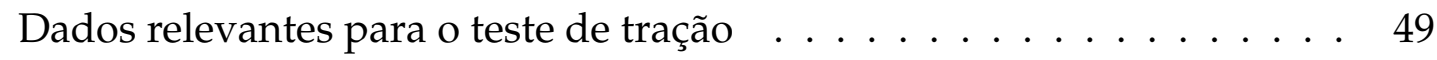

4.2 Parâmetros para testes de diferentes órgãos geometricamente convexos. Dados relevantes para o teste de insuflamento . . . . . . . . . . . . . 50 


\section{Lista de símbolos e siglas}

\begin{tabular}{ll}
\hline Abreviaturas & \\
\hline & \\
AAA & Aneurisma de Aorta Abdominal \\
USP & Universidade de São Paulo \\
FMUSP & Faculdade de Medicina da USP \\
HCFMUSP & Hospital das Clínicas da FMUSP \\
FEUP & Faculdade de Engenharia da Universidade do Porto \\
HAS & hipertensão arterial sistêmica \\
DPOC & doença pulmonar obstrutiva crônica \\
HBP & hiperplasia benigna de próstata \\
MEF & método dos elementos finitos \\
FS & fator de segurança \\
PU & poliuretano \\
PTFE & politetrafluoretileno \\
PET & tereftalato de polietileno
\end{tabular}




\begin{tabular}{|c|c|}
\hline Símbolos & \\
\hline$p_{i}$ & pressão interna \\
\hline$p_{\text {rupt }}$ & pressão interna ao espécime, imediatamente antes de sua ruptura \\
\hline$p_{a b s}$ & pressão absoluta \\
\hline$p_{\text {rel }}$ & pressão relativa \\
\hline$L_{0}$ & comprimento inicial do espécime \\
\hline$L_{f}$ & comprimento final do espécime \\
\hline$D_{i}$ & diâmetro interno \\
\hline$D_{m}$ & diâmetro médio \\
\hline$d_{0}$ & diâmetro inicial do espécime \\
\hline$d_{\text {medio }}$ & diâmetro médio do subgrupo \\
\hline$d_{\max }$ & diâmetro máximo do espécime \\
\hline$r_{i}$ & raio interno (inner radius) \\
\hline$r_{o}$ & raio externo (outer radius) \\
\hline$r_{\max }$ & raio máximo previsto para o espécime em questão \\
\hline$t$ & espessura \\
\hline$t_{0}$ & espessura inicial \\
\hline$V_{i n j}$ & volume injetado \\
\hline$V_{\text {rep }}$ & volume de repouso \\
\hline$V_{\max }$ & volume máximo previsto para o espécime em questão \\
\hline$V_{\text {rupt }}$ & volume no instante da ruptura \\
\hline$F_{\text {rupt }}$ & força de tração no espécime, imediatamente antes de sua ruptura \\
\hline$F_{\max }$ & força máxima prevista para os testes com o equipamento apresentado \\
\hline$F_{F M U S P}$ & força máxima encontrada pela equipe do HCFMUSP \\
\hline$\sigma_{\theta, e}$ & tensão gerada na parede de vasos de pressão de paredes espessas \\
\hline$\sigma_{\text {rupt }}$ & tensão de tração no espécime, imediatamente antes de sua ruptura \\
\hline$E$ & módulo de elasticidade \\
\hline$\epsilon$ & deformação \\
\hline$\epsilon_{\text {rupt }}^{\text {long }}$ & deformação de falência longitudinal, imediatamente antes da ruptura \\
\hline$\epsilon_{\text {rupt }}^{\text {transv }}$ & deformação de falência transversal, imediatamente antes da ruptura \\
\hline$\nu$ & coeficiente de Poisson \\
\hline$\rho$ & densidade da solução fisiológica \\
\hline$x, y$ e $z$ & coordenadas definidas para o equipamento \\
\hline$z$ & coordenada paralela ao eixo axial das membranas a serem testadas \\
\hline$r$ & coordenada radial das membranas a serem testadas \\
\hline$\theta$ & coordenada circunferencial das membranas a serem testadas \\
\hline$a 2 V E 308 L-17$ & especificação da solda em algumas das estruturas do equipamento \\
\hline
\end{tabular}




\section{Capítulo 1}

\section{Introdução}

Aneurismas de artérias são dilatações localizadas, causadas por degeneração ou enfraquecimento de sua parede, ocorrendo com maior frequência em homens que em mulheres, e apresentando complicações, a principal delas sendo a ruptura, também mais precocemente em pacientes do sexo masculino [1].

A maioria dos portadores de aneurisma de aorta abdominal (AAA) infrarrenal não apresenta qualquer sintoma. Dessa forma, a doença é encontrada por acaso em exames clínicos, ultrassom, ressonância ou tomografia com contraste. Em um estudo estatístico de 1977, 46\% dos pacientes com sintomas de rompimento de seus aneurismas de aorta abdominal, que incluem desmaio e fortes dores abdominais e nas costas, vieram a óbito em até 6 horas [2]. Por isso, uma vez detectado, dado que há registros de AAAs com diâmetro aumentando em até $18 \mathrm{~mm}$ ao ano [3], o aneurisma deve ser acompanhado periodicamente e, uma vez que o médico julgar a ruptura iminente, deve-se intervir cirurgicamente.

O conhecimento e a tecnologia atuais permitem que cirurgiões vasculares recomendem intervenção cirúrgica para pacientes cujo diâmetro transverso da aorta abdominal supere, em algum ponto, $55 \mathrm{~mm}$ em sístole, descartando-a para os demais [1]. Esse critério porta consigo um erro estatístico que se manifesta através da ruptura de AAAs de diâmetro inferior a $55 \mathrm{~mm}$ (falso negativo), enquanto outros, de diâmetro superior, não apresentarão qualquer complicação (falso positivo). A distribuição de tensões na parede da aorta depende não somente do diâmetro transverso, mas também do formato, assimetria, perfil e tortuosidade do vaso naquele ponto, além dos remodelamentos decorrentes de carregamento pulsátil [4, 5]. Além disso, esse critério 
não leva em consideração, por exemplo, a rigidez ou alterações teciduais, fatores que atualmente já podem ser determinados de forma não invasiva, através de elastografia por ultrassom.

Por entender que o esforço para reduzir o número de óbitos associados a AAAs deve incluir uma melhor compreensão do comportamento desse tecido, possibilitando, inclusive, uma maior especificidade de tratamentos, o presente trabalho apresenta um equipamento, até hoje inexistente, destinado à coleta, através de teste biaxial, das informações necessárias para melhorar a compreensão das propriedades mecânicas do tecido aórtico, bem como dos tecidos que compõem outros órgãos de geometria semelhante, como a uretra, a safena e o esôfago.

Essa compreensão também será de suma importância na apresentação de tratamentos e alternativas para melhorar a qualidade de vida de portadores de incontinência urinária pós-prostatectomia, bem como na criação de materiais biocompatíveis a serem usados como próteses, em casos de pacientes que precisem ter uma parte de algum desses órgãos removida para a retirada de tumores.

\subsection{Objetivos}

O objetivo deste trabalho é o projeto, a construção e a calibração de um equipamento biaxial que possibilite a estimação de parâmetros de modelos mecânicos de tecidos biológicos, com maior foco dado ao tecido aórtico e, secundariamente, ao da uretra masculina.

De posse dos resultados experimentais de testes realizados com o equipamento aqui apresentado, futuros trabalhos viabilizarão a criação de um modelo matemático para a caracterização dos tecidos, com base nos modelos de Fung e de Holzapfel [6].

O conhecimento do comportamento mecânico da aorta viabilizará o desenvolvimento de um critério mais refinado para a recomendação de intervenção cirúrgica a portadores de AAA. Já o conhecimento do comportamento mecânico da uretra contribuirá para a criação de tecnologia para o controle urinário em pacientes do sexo masculino. 


\section{Capítulo 2}

\section{Revisão Bibliográfica}

O equipamento apresentado tem como foco primário viabilizar a caracterização do tecido da aorta abdominal infrarrenal, trecho em que cerca de $80 \%$ dos aneurismas de aorta ocorrem [7]. Houve uma preocupação, contudo, em expandir a gama de tecidos e órgãos passíveis de submissão ao teste biaxial aqui proposto.

Dessa forma, partiu-se para a investigação de alguns tecidos, para posterior decisão sobre quais deles, e sob quais condições, poderiam ou não ser estudados através do equipamento a ser desenvolvido. A estimação de algumas medidas físicas desses tecidos auxiliou no projeto e no dimensionamento de alguns subsistemas da máquina.

Nesta discussão, abordar-se-ão aspectos do sistema circulatório e realizar-se-á uma compilação de informações específicas sobre aneurismas, bem como de dados estatísticos relevantes, disponíveis na literatura. Em seguida, será discutido, adotado e justificado um modelo apropriado para o cálculo das reações, nos espécimes, resultantes dos esforços impostos a eles, no intuito de auxiliar no projeto do equipamento. Finalmente, serão apresentados e debatidos alguns tipos de testes atualmente realizados com tecidos biológicos, incluindo as vantagens e as desvantagens de cada um, para a tomada de outras decisões quanto ao projeto desenvolvido.

\subsection{O Sistema Circulatório}

O sistema circulatório é dividido entre as circulações pulmonar e sistêmica. O coração recebe, no átrio direito, sangue rico em $\mathrm{CO}_{2}$, pelas veias cavas inferior e superior. Dali, 
passa pela válvula tricúspide, chegando ao ventrículo direito. A artéria pulmonar leva esse sangue aos pulmões, onde ocorrem as trocas gasosas responsáveis por sua oxigenação. O sangue, então, segue para o átrio esquerdo, por meio das veias pulmonares. Em seguida, passa pela válvula mitral, ou bicúspide, chegando ao ventrículo esquerdo, de onde é impulsionado, através da válvula aórtica, para a aorta.

A aorta pode ser compreendida como um conduto principal central que, por meio de seus ramos, como o tronco braquiocefálico, a artéria carótida comum esquerda e a artéria subclávia esquerda, dentre outros e, a partir destes, através de ramificações de diâmetro decrescente e em número crescente, conduz o sangue, rico em $\mathrm{O}_{2}$, para a irrigação de todos os tecidos. Conforme os percorre, a concentração de $O_{2}$ no sangue vai diminuindo e, a de $\mathrm{CO}_{2}$, vai aumentando. Segue, então, para o sistema venoso, responsável, dentre outros, pela coleta e recondução de volta ao átrio direito, através das veias cavas inferior e superior, para as quais todo o sistema venoso converge.

A circulação pulmonar começa na saída do ventrículo direito e termina ao entrar pelo átrio esquerdo, e a sistêmica inicia ao sair pela aorta, terminando ao voltar pelas veias cavas.

A figura 2.1 mostra uma seção transversal da artéria femoral. Seu formato irregular se dá pelas tensões internas inerentes à formação do tecido e à presença de outros órgãos em seus arredores, exercendo pressão sobre ela. Para efeito de simplificação, o presente trabalho aproximou as seções transversais dos tecidos e dos órgãos abordados a círculos ou elipses, cujas áreas são calculadas mais facilmente, uma vez que as irregularidades no formato da seção transversal são imprevisíveis, assim como ainda é imprevisível a variação da espessura da parede dessas estruturas, tanto longitudinal quanto circunferencialmente [8]. 


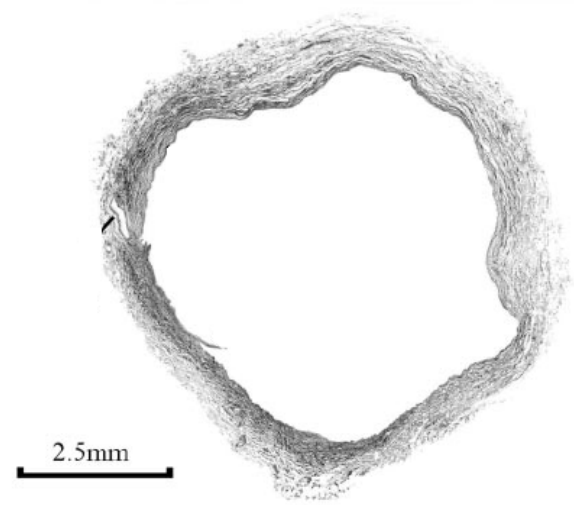

Figura 2.1: Seção transversa da artéria femoral. Fica clara a irregularidade de sua sessão transversal, assim como em outros vasos sanguíneos e órgãos, explicada pela presença de outras estruturas em seus arredores e pela presença de tensões desde os primórdios da formação do tecido. Extraído e adaptado [9]

\subsection{Aneurismas}

Em aortas abdominais infrarrenais, consideram-se normais diâmetros de até $20 \mathrm{~mm}$. Definem-se como aneurismáticas as aortas com dilatações a partir de 50\%, e como ectasias aquelas com deformações de até $50 \%$ [10]. Ectasias são consideradas formações pré-aneurismáticas, por isso, merecem atenção do cirurgião vascular.

Seria natural imaginar que, diante do aumento do diâmetro da aorta, sua espessura diminuísse. O carregamento pulsátil, contudo, promove constante remodelamento, o que minimiza esse efeito [11].

Estudos do tecido aórtico abdominal indicam que, dentre os principais fatores determinantes de seu comportamento biomecânico, destacam-se a quantidade de fibras colágenas e elásticas, assim como a proporção entre elas [12]. As fibras colágenas são cerca de mil vezes mais rígidas que as elásticas [13], sendo sua função manter o diâmetro do vaso dentro do limite fisiológico [14].

Ao contrário das aortas abdominais saudáveis, as aneurismáticas apresentam um comportamento aproximadamente isotrópico [15, 16], provavelmente devido à diminuição gradual de elastina [17], conforme aumenta a quantidade de colágeno, que se redistribui na parede do vaso em direções aleatórias, conferindo ao tecido um caráter mais isotrópico e aumentando a sua rigidez [1, 16, 18]. Além disso, o fato de 
as fibras colágenas se distribuírem em direções aleatórias na parede da aorta diminui a deformação necessária para que elas sejam recrutadas, o que ajuda a explicar a diminuição da elasticidade desse tecido [1, 15].

Aneurismas podem ser considerados doenças arteriais, já que, nesses pacientes, a elasticidade da aorta é inferior ao que se considera normal [19]. O diâmetro da aorta varia em função de fatores como idade, sexo e altura [20], sendo que a adolescência é o período em que ele aumenta mais rapidamente, até, em média, os 20 anos de idade. Observa-se, também, que indivíduos de estatura superior a 1,70 m têm, em média, diâmetro maior que os de estatura inferior [10].

A figura 2.2 mostra como o diâmetro variou, em média, para 3 grupos analisados: um composto por jovens do sexo masculino; um segundo, por homens de meia idade; e um terceiro, por homens idosos.

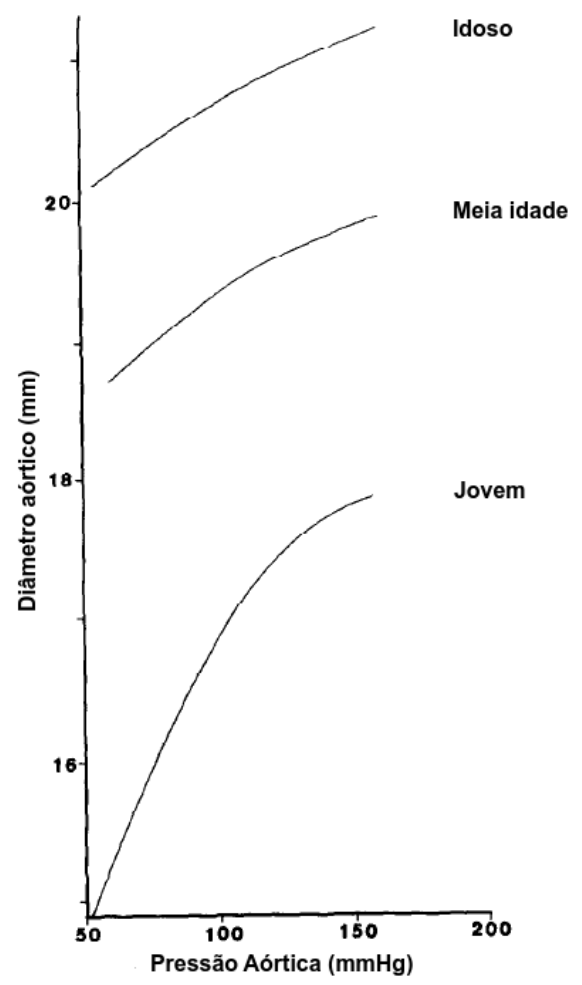

Figura 2.2: Variação do diâmetro aórtico, em função da pressão arterial, em 3 grupos de pacientes do sexo masculino, pertencentes a faixas etárias distintas. Fica evidente a redução da distensibilidade do tecido com o avanço da idade. Extraído e adaptado [18]

A figura 2.3, por sua vez, foi obtida a partir de 3 pacientes do sexo feminino, 
ilustrando a diminuição da distensibilidade do tecido aórtico com a idade.

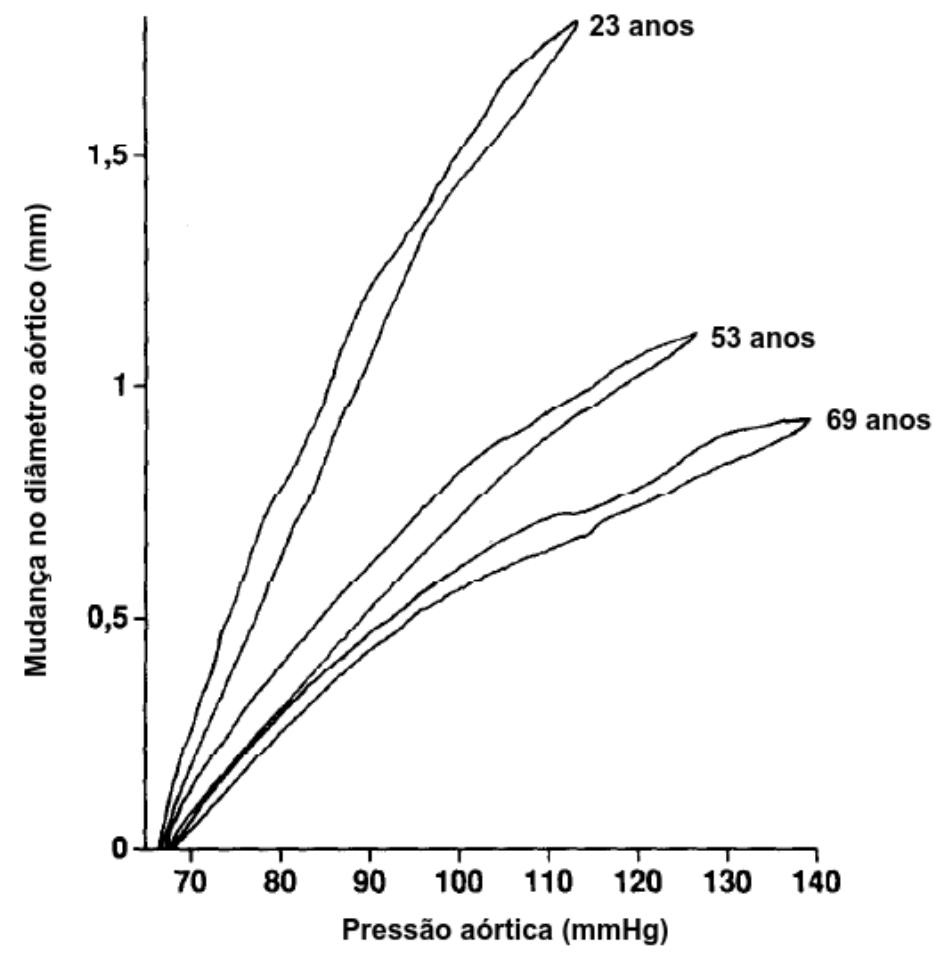

Figura 2.3: Variação percentual do diâmetro em função da pressão arterial, em 3 pacientes do sexo feminino pertencentes a faixas etárias distintas, relacionando o avanço da idade à diminuição da elasticidade do tecido aórtico. Extraído e adaptado de [18]

Um estudo conduzido com 645 indivíduos demonstrou que o diâmetro aórtico não sofreu influência significativa na presença ou não de coronariopatia, hipertensão arterial sistêmica (HAS) ou doença pulmonar obstrutiva crônica (DPOC). Por outro lado, mostrou que indivíduos com maior intensidade de aterosclerose apresentavam diâmetro aproximadamente 5, 22\% maior que aqueles sem essa condição, sem separar por sexos [10].

Há evidências de que a incidência de AAA tenha uma correlação positiva com tabagismo, obesidade, sedentarismo, hipercolesterolemia e etnia branca, o que lhe confere um caráter multifatorial [21, 22, 23, 24], com componente genético de, aproximadamente, $70 \%$ [25].

AAAs ocorrem de duas a quatro vezes mais em homens que em mulheres. Após os 55 anos de idade, a prevalência no sexo masculino aumenta muito rápido, alcançando seu pico, por volta de $5,9 \%$, entre os 80 e os 85 anos. Já no sexo feminino, a prevalência 
começa a aumentar rapidamente após os 70 anos de idade, atingindo o pico de $4,5 \%$ por volta dos 90 anos de idade. O início das rupturas em homens se dá, em média, 10 anos mais cedo que em mulheres [26].

A mortalidade em cirurgias eletivas de correção de AAAs vem caindo por diversos fatores, como os constantes avanços no combate a infecções hospitalares, o desenvolvimento de técnicas cada vez menos invasivas, melhores avaliações e acompanhamento pré-operatórios, avanços no desenvolvimento e aperfeiçoamento da anestesia para esse tipo de intervenção e cuidados pós-operatórios mais adequados [27]. Hoje, a mortalidade associada a esse tipo de intervenção varia entre 3 e $10 \%$ [1], dependendo também da estrutura hospitalar de que o cirurgião dispõe, tanto no momento da realização da cirurgia, quanto antes e depois dela [27].

Atualmente, são mais comuns as intervenções conhecidas como Endovascular Aneurysm Repair (EVAR), técnica menos invasiva que a cirurgia aberta. Realizada com anestesia local ou raquidiana, a EVAR reduziu o tempo de internação e a necessidade de transfusão de sangue. Nela, é introduzido, através da artéria femoral, um cateter contendo a prótese a ser posicionada na região enfraquecida da aorta, o que eliminou a necessidade de incisão abdominal.

Próteses endovasculares utilizam materiais poliméricos biocompatíveis na superfície em contato com o organismo, como o PTFE (politetrafluoretileno ou Teflon) e o Dacron (tereftalato de polietileno ou PET). Já a estrutura dessas próteses utiliza metal com memória de forma, o Nitinol, liga de níquel e titânio. A propriedade de memória de forma é essencial para o posicionamento e manutenção da prótese no local correto. $\mathrm{O}$ sangue passa a fluir através da prótese, e a região do aneurisma deixa de ser solicitada, reduzindo drasticamente a probabilidade de ruptura do vaso.

A figura 2.4 mostra uma aorta com dois aneurismas evidenciados. 


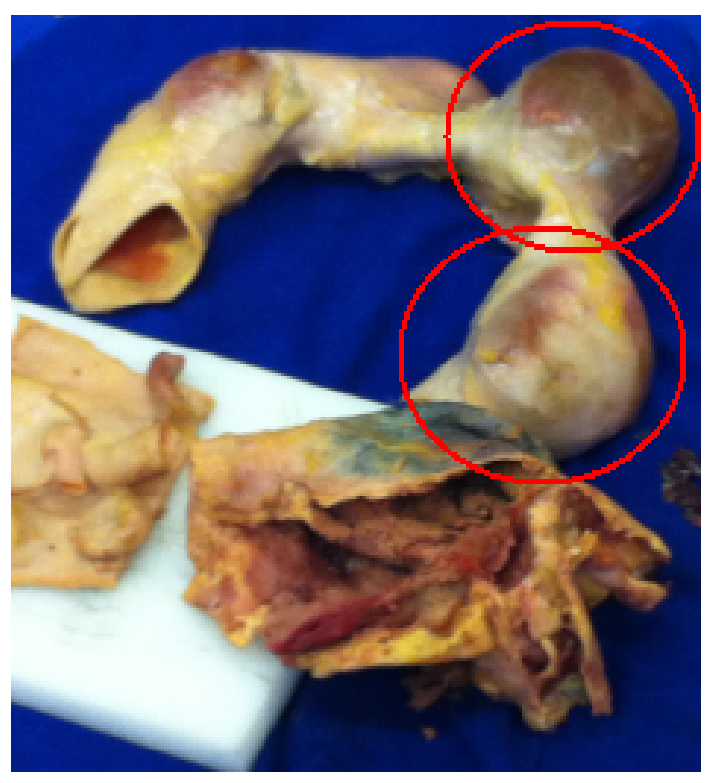

Figura 2.4: Aorta com 2 aneurismas destacados. Imagem obtida no HCFMUSP com permissão do Dr. José Augusto Tavares Monteiro

\subsection{Vasos de Pressão}

Conforme mencionado na seção 2.1. estruturas biológicas tubulares tendem a possuir, ao longo do seu comprimento e circunferência, parede de espessura variável. O presente trabalho considerou constantes, em ambos os eixos, as espessuras desses órgãos. Essas assunções permitiram a adoção da teoria de vasos de pressão [28] no cálculo de parâmetros físicos dos espécimes na presença e na ausência dos esforços pretendidos e, consequentemente, na determinação de alguns parâmetros físicos da máquina de testes em si, como as tensões geradas nas paredes pela presença desses esforços.

Segundo essa teoria, ao se compararem espécimes de mesmo comprimento, quanto maior a diferença entre os diâmetros interno e externo, maior a diferença entre as áreas das superfícies correspondentes em cada parede, induzindo uma diferença maior entre as tensões geradas em cada uma delas. Como os órgãos analisados apresentaram, por vezes, uma diferença significativa entre os raios das paredes interna e externa, decidiu-se representá-los por vasos de pressão de paredes espessas, no intuito de se obterem resultados mais próximos à realidade.

Não se sabe ainda se o rompimento de aortas, saudáveis ou aneurismáticas, se 
inicia na parede interna ou na externa [29]. Dado que esse tipo de tecido humano é dúctil, ou seja, capaz de deformar até a fratura, foi analisada, através de um modelo em elementos finitos (MEF), com o software comercial Ansys, a tensão de Von Mises na parede de um modelo genérico de vaso, submetido apenas a pressão interna. Verificou-se, conforme mostra a figura 2.5, que essa tensão é maior na parede interna que na externa. Assim, as tensões calculadas e apresentadas para cada órgão analisado referir-se-ão sempre à sua parede interna.

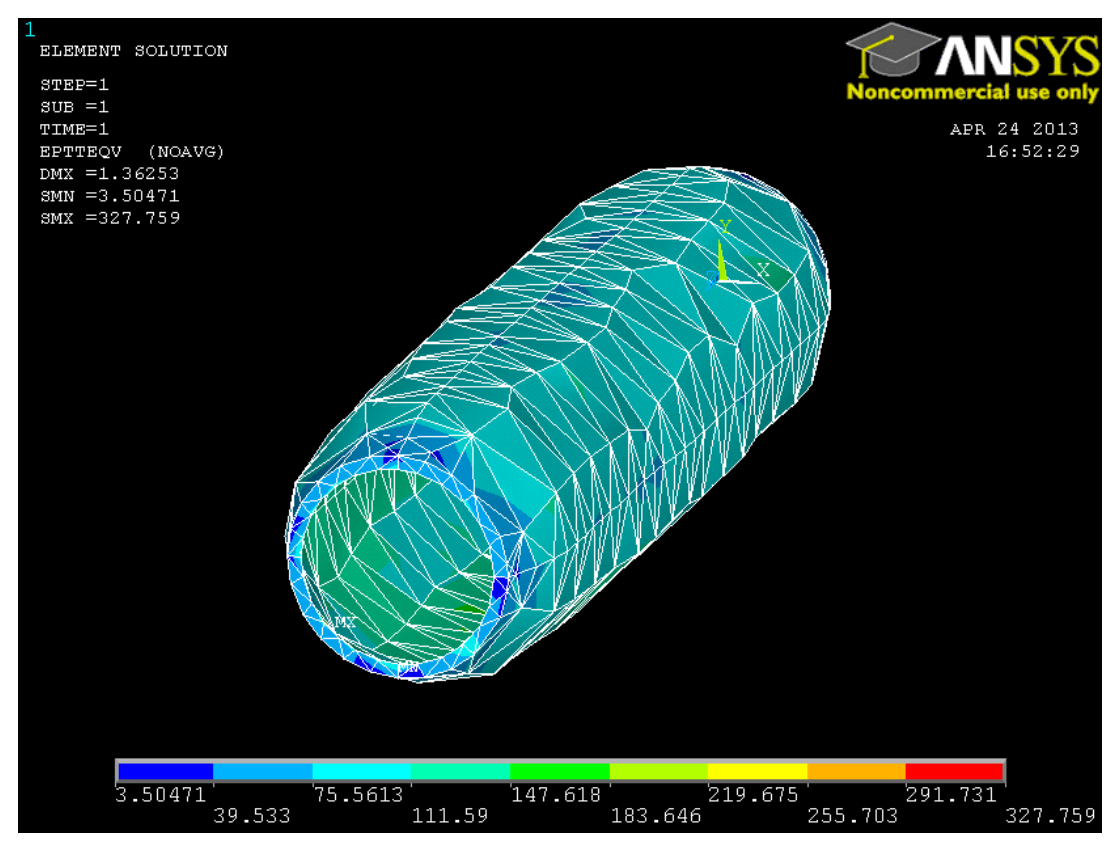

Figura 2.5: Tensões de Von Mises no modelo de vaso de pressão de paredes espessas, resultantes de carregamento interno, evidenciando que as maiores tensões surgem na parede interna. Imagem obtida com o software comercial Ansys.

A figura 2.6 representa a seção transversa de uma estrutura tubular, onde $D_{i}$ representa o diâmetro interno, $D_{m}$, o diâmetro médio, e $t$, a espessura do vaso. Pode-se calcular $D_{m}$ através da equação (2.1). No caso de aortas saudáveis, $D_{i}$ é aproximadamente igual a $20 \mathrm{~mm}, t=1,42 \mathrm{~mm}$ e $D_{m}=21,42 \mathrm{~mm}$ [1].

$$
D_{m}=D_{i}+2 \cdot \frac{t}{2}
$$




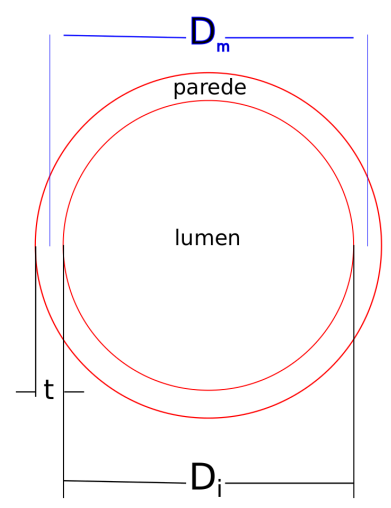

Figura 2.6: Representação simplificada da seção transversal de uma estrutura tubular

Na presença de pressão interna $\left(p_{i}\right)$, surge, na parede do espécime, uma tensão $\left(\sigma_{\theta}\right)$ na direção circunferencial $(\theta)$, que tende a rompê-lo. Em vasos de pressão de paredes espessas, essa tensão, na parede interna $\left(\sigma_{\theta}\right)$, é dada pela equação (2.2),

$$
\sigma_{\theta}=p_{i} \cdot\left[\frac{r_{o}^{2}+r_{i}^{2}}{r_{o}^{2}-r_{i}^{2}}\right]
$$

onde $r_{i}$ denota o raio da parede interna do vaso, e $r_{o}$, o raio da parede externa [30].

A equação (2.2) mostra que, quanto maior a pressão interna, maior a tensão gerada na parede e, portanto, maior a probabilidade de ruptura do vaso. A análise dessa equação também permite concluir que, ao se compararem espécimes de mesmo raio externo $\left(r_{o}\right)$, aquele que apresentar raio interno $\left(r_{i}\right)$ maior, ou seja, espessura menor, estará submetido a uma tensão maior na parede. Fica evidente, assim, que, quanto mais fina a parede, mais provável será a sua ruptura, ceteris paribus.

\subsection{Literatura de metodologias}

Para melhorar a compreensão do comportamento mecânico de um determinado tecido, são realizados ensaios cujos dados de esforços e de deformações são armazenados, permitindo a criação de modelos matemáticos. De posse de um modelo com boa aderência, pode-se prever com melhor precisão o comportamento desse tecido quando submetido a esforços conhecidos.

Diversos modelos para a caracterização de tecidos estão disponíveis na literatura, diferindo entre si de acordo com as características do material a ser estudado. 
Alguns modelos oferecem excelente aderência somente na caracterização de tecidos de comportamento isotrópico, enquanto outros, mais complexos, descrevem também o de tecidos anisotrópicos. Alguns caracterizam tecidos compressíveis, outros, apenas os incompressíveis.

Uma vez escolhido o modelo mais compatível com o material em estudo, determina-se a função de energia de deformação para aquele tecido, no caso, a aorta abdominal. Para isso, muitos testes vêm sendo realizados, tanto em espécimes retirados de pacientes portadores ou não de AAAs, quanto naqueles provenientes de indivíduos cujas aortas ainda possam ser estudadas. Alguns desses testes serão aprofundados a seguir.

\subsubsection{Disponíveis}

Dentre os testes biaxiais realizados atualmente, destacam-se três tipos: o cilíndrico, o plano e o do tipo bolha.

Durante qualquer teste com tecidos biológicos, os espécimes têm suas extremidades cuidadosamente presas a garras, de modo a não permitir que os esforços a serem aplicados provoquem movimento relativo na área de fixação, ou que haja qualquer dano naquela região do tecido, fragilizada pela propensão à concentração de tensões.

Para o teste biaxial cilíndrico de um órgão tubular, utilizam-se seções inteiras do órgão, retiradas, normalmente, de cadáveres. A figura 2.7 apresenta uma máquina desse tipo.

Materiais biológicos são compostos, em grande parte, por água. Na área de fixação do espécime, pressão é exercida sobre o tecido, causando exsudação. Os ensaios em si provocam perdas adicionais, à medida em que sua geometria é alterada pela deformação forçada. Por isso, todo o líquido em contato com os espécimes durante os ensaios deve ser isotônico, prevenindo que a osmose provoque alterações adicionais na quantidade de líquidos presentes originalmente nos tecidos, conservando, assim, suas características mecânicas pelo maior tempo possível. 


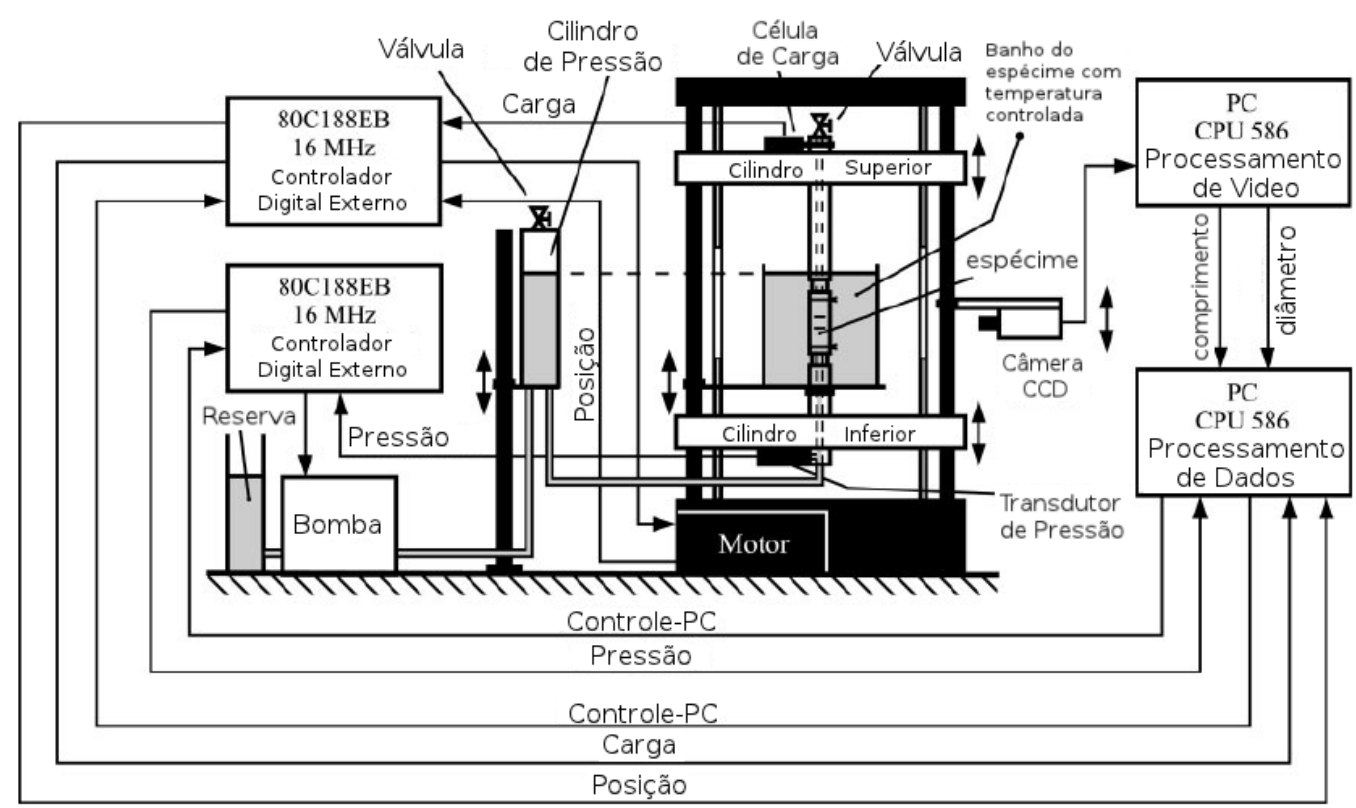

Figura 2.7: Esquema de montagem de uma máquina de teste biaxial cilíndrico, tipo de equipamento a ser projetado e montado no presente trabalho. Fonte: [9]

A curvatura dos tecidos tubulares gera, ao longo da vida do paciente, tensões residuais nas suas camadas externas. Essas tensões podem ser aproximadamente previstas por modelos matemáticos, mas não podem ser generalizadas ou determinadas com precisão para todos os pacientes. Isso é notório ao se analisarem diferentes aneurismas, com formatos, distribuições de colágeno e de elastina e dimensões distintos. O teste biaxial cilíndrico leva vantagem sobre os demais, pelo fato de considerar a curvatura original dos tecidos. Por essa razão, optou-se pelo desenvolvimento de um equipamento deste tipo.

Os demais tipos de ensaios biaxiais usam espécimes cortados não só perpendicularmente à direção axial, mas também paralelamente a ela, levando as tensões internas residuais armazenadas em sua parede a serem desprezadas, consequentemente alterando o resultado obtido.

Atualmente, testes biaxiais planos vêm sendo conduzidos na Universidade do Porto, em Portugal. Esse tipo de teste considera carregamento somente no plano do tecido, não levando em conta os esforços na direção normal a ele, uma clara limitação, apesar de sua inegável contribuição para a ciência. Um experimento desse tipo é mostrado na figura $2.8[6]$. 


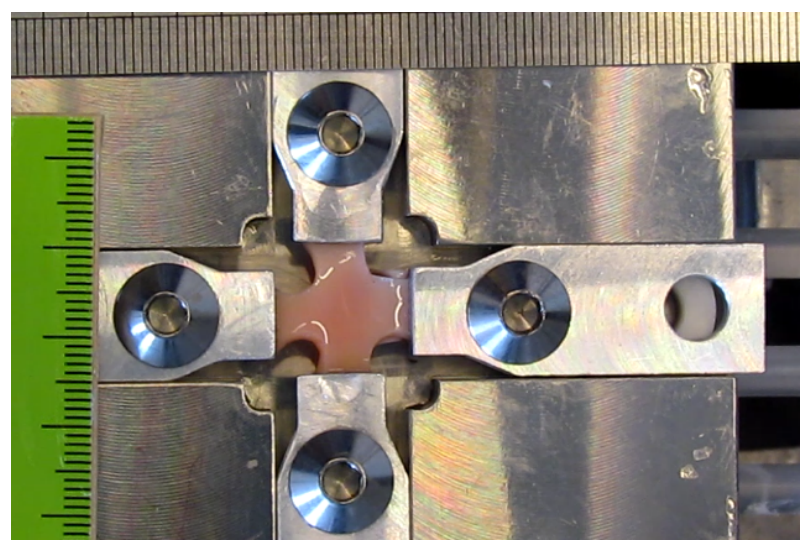

Figura 2.8: Teste biaxial plano de tecido aórtico suíno. São considerados somente carregamentos no plano do tecido, e ignoradas as tensões residuais armazenadas nas diferentes camadas de sua parede. Imagem cedida, autorizada e adaptada [6]

O terceiro tipo de teste analisado foi o equibiaxial do tipo bolha, que utiliza uma câmara contendo um furo em uma das paredes. Sobre ela, o espécime é posicionado e fixado. Internamente à câmara, atua uma pressão variável e controlável, e a distensão do espécime é filmada. De posse das imagens das deformações e dos carregamentos aplicados em cada um desses instantes, é possível calcular uma série de parâmetros mecânicos, seguindo um modelo matemático apropriado. A figura 2.9 ilustra algumas imagens provenientes de um ensaio desse tipo. As desvantagens desse tipo de teste incluem o fato de o carregamento aplicado ser virtualmente igual nos dois eixos do plano do espécime, restringindo os esforços aplicáveis e limitando o estudo do tecido em questão. Além disso, assim como no teste biaxial plano, para ser fixado ao equipamento, o tecido é cortado em dois eixos perpendiculares, levando, conforme já explicado, à perda de parte das informações referentes ao seu comportamento. 


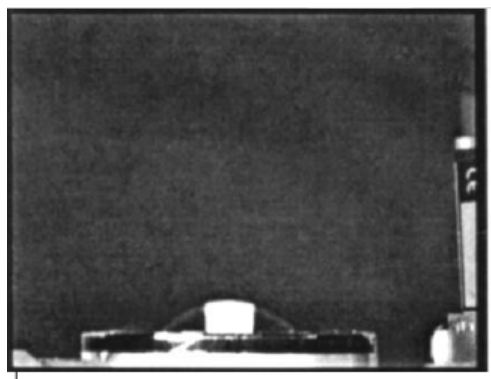

$P=0.288$ bar $\left(\lambda_{0 \theta}=1.17\right)$

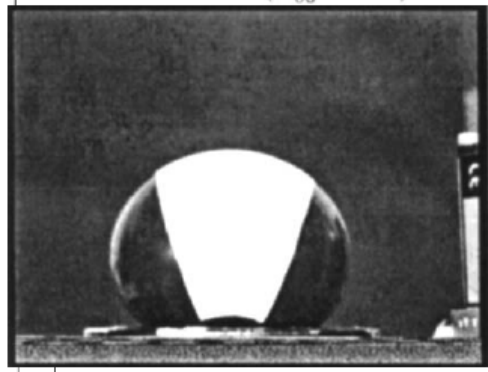

$P=0.605$ bar $\left(\lambda_{\theta \theta}=4.25\right)$

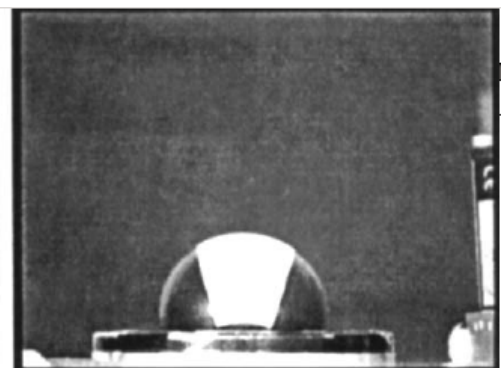

$P=0.598$ bar $\left(\lambda_{0 \theta}=2.52\right)$

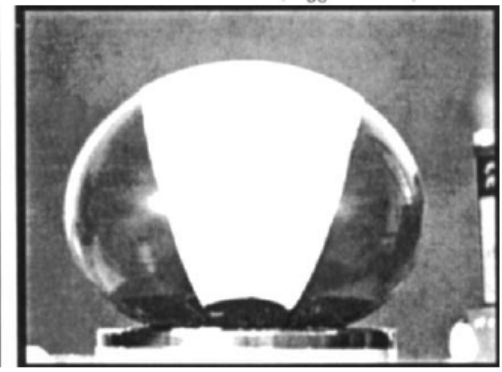

$\mathrm{P}=0.799$ bar $\left(\lambda_{\theta \theta}=5.85\right)$

Figura 2.9: Teste biaxial do tipo bolha de uma membrana elastomérica. $\mathrm{O}$ carregamento é virtualmente igual nos dois eixos do plano do espécime, limitando o estudo do tecido. Imagem extraída e adaptada [31]

\subsubsection{FMUSP}

Ensaios de tração uniaxial de aorta abdominal vêm sendo conduzidos no Hospital das Clínicas da Faculdade de Medicina da Universidade de São Paulo (HCFMUSP). Responsável por esses experimentos, o Professor Doutor Erasmo Simão da Silva utiliza um equipamento comercial de tração da marca Instron (figura 2.10(a)).

Os espécimes de AAA testados são retirados de cadáveres ou de pacientes mandados para cirurgia corretiva. Tratam-se de tiras de aorta abdominal com pouco mais de $20 \mathrm{~mm}$ de comprimento, das quais são removidos tecidos gordurosos e eventuais trombos. Divididas em duas partes de $5 \mathrm{~mm}$ de largura cada, uma delas é submetida a testes mecânicos e a outra, a exame histológico. A combinação dos dois resultados auxilia na compreensão da relação entre a força da parede arterial e sua composição histológica [1]. 


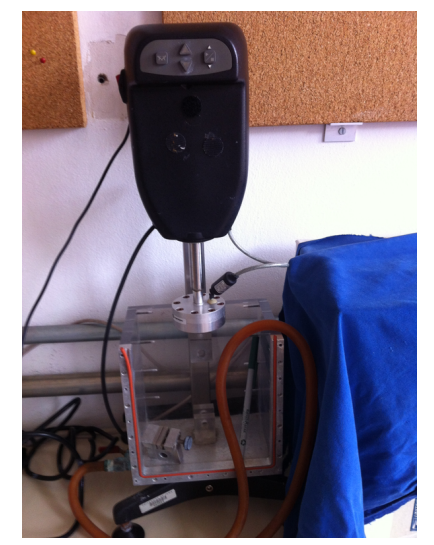

(a) Máquina Instron

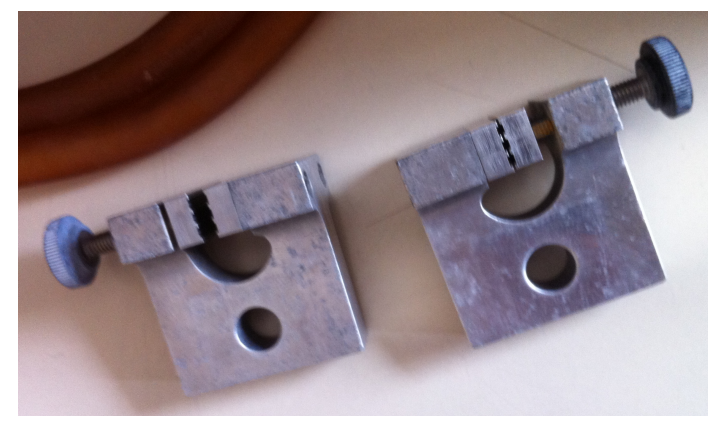

(b) Garras

Figura 2.10: Máquina de testes e garras usadas nos testes conduzidos no HCFMUSP. Imagens cedidas e autorizadas [29]

Durante o teste mecânico, o espécime é fixado à máquina por meio de garras projetadas especialmente para esse fim (figura 2.10(b)), e fica imerso, à temperatura ambiente, em solução isotônica, para evitar osmose, já que qualquer alteração na concentração de água presente no tecido pode alterar suas propriedades bioquímicas e mecânicas. Pelo mesmo motivo, o espécime não pode, em nenhum momento, ter sido congelado ou mantido em formol ou em outros conservantes. Ele é apenas refrigerado a $4{ }^{\circ} \mathrm{C}$. Deve, também, ser testado em menos de 48 horas após a dissecção [1, 10].

A fixação não pode ser muito fraca, sob o risco de a extremidade do espécime se soltar da garra durante o ensaio. Por outro lado, uma fixação forte demais, por provocar concentração de tensões, fragilizaria o espécime, aumentando a probabilidade de ocorrer uma ruptura na região das garras. Para garantir que o espécime está inicialmente esticado, uma pré-carga de $0,01 \mathrm{~N}$ é aplicada a ele. A distância inicial entre as garras é de $20 \mathrm{~mm}$.

Este tipo de tecido tem memória de carregamento. Por isso, é realizado um pré-condicionamento, durante o qual o espécime é deformado em 5\%, a uma velocidade de $20 \%$ da distância inicial entre garras por minuto, taxa da deformação imposta à parede da aorta durante o ciclo cardíaco [15].

Em seguida, é permitido ao espécime retomar o comprimento original, durante o mesmo intervalo de tempo. Esse ciclo é repetido 10 vezes, para alinhar as fibras do tecido, na intenção de que exiba comportamento mais próximo ao fisiológico. Terminado o pré-condicionamento, o ensaio de tração é imediatamente iniciado. Nele, 
o espécime é tracionado na mesma velocidade, até a ruptura. Caso rompa muito próximo às garras, o teste é considerado inválido, por entender que a falha pode ter sido ocasionada por concentração de tensões na região de fixação, fenômeno muito comum neste tipo de ensaio.

Durante os testes conduzidos no HCFMUSP, a maior elongação encontrada foi de $85 \%$. Os resultados desses experimentos foram muito úteis para o presente trabalho, tendo fornecido dados importantes para a metodologia descrita a seguir. 


\section{Capítulo 3}

\section{Metodologia Empregada}

O projeto do equipamento partiu da listagem e do dimensionamento dos órgãos cujos modelos mecânicos fossem de interesse para a Medicina, e cujo formato fosse compatível com o tipo de teste a ser realizado. A literatura e os doutores Erasmo Simão da Silva, Jose Augusto Tavares Monteiro e Paulo Rodrigues forneceram alguns dos dados relevantes para o dimensionamento dos subsistemas, enquanto outros dados foram calculados ou estimados a partir daqueles.

Determinados os esforços necessários para romper os espécimes e as máximas dimensões atingidas por eles, tanto longitudinal quanto transversalmente, as opções para cada subsistema do equipamento foram listadas. Para cada decisão, foram consideradas tanto a viabilidade econômica quanto a eficácia da alternativa como solução.

A caracterização dos tecidos será feita a partir dos dados obtidos experimentalmente com o equipamento aqui apresentado, e usará modelos da Mecânica do Contínuo. É objeto da dissertação de Ana Isabel Arroyave Guzmán [6], não fazendo parte, portanto, do escopo deste trabalho.

\subsection{Estimação de dados não encontrados na bibliografia}

Tendo em vista a geometria necessariamente convexa dos órgãos e tecidos a serem testados pelo equipamento, estudou-se a viabilidade de se testarem aortas abdominais aneurismáticas humanas de diversos diâmetros, aortas abdominais humanas saudáveis, aortas descendentes suínas, veias cavas humanas, safenas 
humanas, uretras masculinas, esôfagos humanos, intestinos delgados humanos e intestinos grossos humanos.

Para cada órgão, foi estimado o maior número possível de parâmetros, dentre os seguintes:

- $V_{\text {rep }}$ : volume de repouso, em $m l$;

- $V_{\text {rupt }}$ : volume máximo observado imediatamente antes da ruptura sob insuflamento puro, em $\mathrm{ml}$;

- $V_{i n j}$ : volume a ser injetado no espécime, em $m l$, definido conforme a equação (3.1),

$$
V_{\text {inj }}=V_{\text {rupt }}-V_{\text {rep }}
$$

- $V_{i n j, m a x}:$ volume máximo a ser injetado no espécime, considerando tração e insuflamento concomitantes, em $m l$, definido conforme a equação (3.2),

$$
V_{\text {max }}=V_{\text {inj }} \cdot\left(1+\epsilon_{\text {rupt }}^{\text {long }}\right)
$$

- $p_{\text {rupt }}$ : pressão máxima, observada imediatamente antes da ruptura sob insuflamento puro, em $k P a$;

- $L_{0}$ : comprimento nominal do espécime a ser testado, sem esforços aplicados além da pré-carga, em $m m$;

- $L_{f}$ : comprimento máximo, observado imediatamente antes da ruptura sob tração pura, em $m m$;

- $F_{\text {rupt }}$ : força de tração máxima, observada imediatamente antes da ruptura sob tração pura, em $N$;

- $\sigma_{\text {rupt }}$ : tensão longitudinal máxima, observada imediatamente antes da ruptura, em $k P a$;

- $d_{0}$ : diâmetro inicial, ou distância entre as paredes externas na ausência de tração e de insuflamento, em $m m$; 
- $d_{\text {max }}$ : diâmetro máximo, ou distância entre as paredes externas, imediatamente antes da ruptura por insuflamento puro, em $\mathrm{mm}$;

- $t$ : espessura da parede do tecido, medida na ausência de tração e de insuflamento, em $m m$;

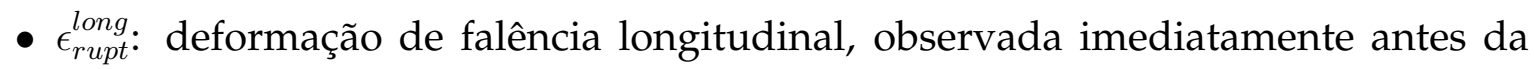
ruptura sob tração pura, em \%, conforme a equação (3.3),

$$
\epsilon_{\text {rupt }}^{\text {long }}=\frac{\Delta L}{L_{0}}
$$

- $\epsilon_{\text {rupt }}^{\text {transv }}$ : deformação de falência transversal, observada imediatamente antes da ruptura sob insuflamento puro, em \%, conforme a equação (3.4),

$$
\epsilon_{\text {rupt }}^{\text {transv }}=\frac{\Delta d}{d_{0}}
$$

Cabe ressaltar que $V_{i n j, \text { max }}$ considera, a partir de $V_{i n j}$, deformação longitudinal. É um valor superestimado, uma vez que, sob tração em dois sentidos, o espécime tenderá a deformar menos em cada um deles. A superestimação, contudo, é intencional, uma vez que se quer garantir a ruptura de todos os espécimes, condição necessária para a caracterização dos tecidos.

Nem todos os valores obtidos referem-se exatamente à ruptura dos tecidos em questão, dada a falta de informações, na literatura, sobre esse tipo de ensaio em alguns órgãos, como a uretra humana. Estima-se, contudo, que os valores calculados e apresentados na seção 4.1 sejam condizentes com a ordem de grandeza que levará à ruptura. Ensaios conduzidos com o presente equipamento permitirão o refinamento desses valores.

Os parâmetros descritos foram necessários para o projeto do equipamento aqui apresentado, cujos resultados viabilizarão a definição da função de energia de deformação, a partir da qual o material será caracterizado, seguindo metodologia baseada nos modelos de Holzapfel e de Fung [6].

No cálculo da tensão de ruptura por tração, foi usada a relação (3.5), em que é considerada a área inicial pelo fato de, na literatura, as medições terem sido feitas 
apenas no início dos testes.

$$
\sigma=\frac{F}{A_{i}}
$$

Quando um material é submetido à tração em um sentido, suas dimensões nos sentidos perpendiculares ao primeiro são reduzidas por um fator característico do material, conhecido como coeficiente de Poisson $(\nu)$. Para materiais isotrópicos, vale a relação 3.6 ,

$$
\nu=\frac{-\epsilon_{y}}{\epsilon_{x}}=\frac{-\epsilon_{z}}{\epsilon_{x}}
$$

onde $\epsilon$ denota a deformação, e os eixos $x, y$ e $z$ são mostrados na figura 3.1, seguindo o sistema cartesiano de coordenadas.

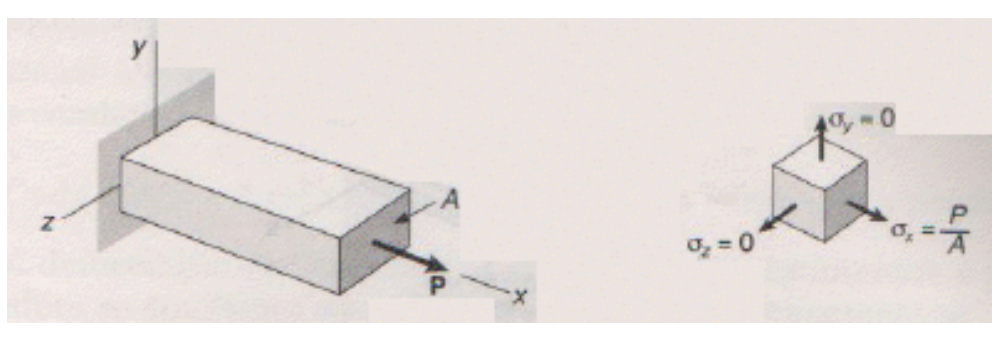

Figura 3.1: Bloco sujeito a carregamento exclusivamente axial. Fonte: [28]

No caso dos espécimes testados, o eixo $x$ da figura 3.1 equivale ao eixo longitudinal do espécime, $z$, conforme será explicado em momento oportuno. Para a membrana dos espécimes, serão usadas coordenadas cilíndricas. A relação entre os sistemas cartesiano e cilíndrico, transformando as coordenadas $y$ e $z$ nas coordenadas $\theta$, circunferencial, e $r$, radial, obedece ao conjunto de equações a seguir,

$$
\left\{\begin{array}{l}
\theta=\arctan \left(\frac{z}{y}\right) \\
r^{2}=y^{2}+z^{2}
\end{array}\right.
$$

Vale lembrar, contudo, que materiais biológicos dificilmente serão isotrópicos, por fatores como a disposição das fibras de seus tecidos, conforme descrito na seção 2.2 .

Levando em conta que a equação (3.5) considera a área inicial e que, conforme indica a equação (3.6), essa área diminui conforme o espécime é tracionado 
longitudinalmente, pode-se afirmar que a tensão obtida na equação (3.5) é subdimensionada.

Para órgãos tubulares, como o esôfago, a aorta e a uretra, foi, algumas vezes, usado o fato de que o volume é uma função linear, proporcional ao quadrado do raio. No cálculo da tensão, $\sigma_{x}$, gerada durante o ensaio de tração pura, a equação (3.5) pode ser reescrita como (3.7), que ainda retorna uma tensão subdimensionada,

$$
\sigma_{x}=\frac{F}{\pi\left[r_{o, 0}^{2}-\left(r_{o, 0}-t_{0}\right)^{2}\right]}
$$

sendo $r_{o, 0}$ o raio externo inicial $\left(=\frac{d_{0}}{2}\right)$ e $t_{0}$ a espessura inicial $(=t)$, ambos obtidos experimentalmente.

Em regime elástico, materiais homogêneos carregados axialmente sofrerão deformação obedecendo à Lei de Hooke,

$$
\epsilon_{x}=\frac{\sigma_{x}}{E}
$$

onde $\epsilon_{x}$ denota a deformação no eixo $x, \sigma_{x}$ denota a tensão nesse eixo, e $E$ denota o módulo de elasticidade.

Das equações (3.6) e (3.8), chega-se à equação (3.9),

$$
\epsilon_{y}=\epsilon_{z}=\frac{\nu \sigma_{x}}{E}
$$

Os dados apresentados nas seis primeiras linhas das tabelas 4.1 e 4.2 (páginas 49 e 50, respectivamente) referem-se a artérias aneurismáticas de diferentes diâmetros externos, e são o resultado dos experimentos conduzidos, no HCFMUSP, pelo Professor Doutor Erasmo Simão da Silva e sua equipe. A espessura dos espécimes foi medida com paquímetro digital.

Nessas tabelas, o comprimento padrão foi definido em $100 \mathrm{~mm}$. Entre as ramificações para as artérias renais e a bifurcação para as artérias ilíacas, a aorta de um humano adulto tem, em média, de 100 a $120 \mathrm{~mm}$ de comprimento [29]. No cálculo do volume máximo, foi considerada uma seção transversal constante em todo o seu comprimento, no intuito de disponibilizar um volume de líquido suficiente para o insuflamento de qualquer espécime. 
A máquina e o experimento descritos em 2.4.2 forneceram a elongação de muitos espécimes. Como, conforme a seção 2.2, aortas abdominais aneurismáticas são aproximadamente isotrópicas, adotou-se a aproximação $\epsilon_{\text {rupt }}^{\text {transv }}=\epsilon_{\text {rupt }}^{\text {long }}$. Sob tração longitudinal pura, seu comprimento final pode ser calculado a partir da equação (3.3), da qual se obtém a equação (3.10),

$$
L_{f}=L_{0} \cdot\left(1+\epsilon_{\text {rupt }}^{\text {long }}\right) .
$$

A equipe do Professor Doutor Erasmo Simão da Silva calculou a força máxima atingida na ruptura de cada um de seus espécimes, de $5 \mathrm{~mm}$ de largura. De posse dos resultados, foi criada uma planilha com as médias de diâmetro transverso e de força máxima de ruptura, agrupadas em diversas faixas de diâmetro. A equação (3.11) permitiu o cálculo da força máxima correspondente necessária durante o ensaio de tração longitudinal pura dos espécimes aqui propostos, para os quais o perímetro é tomado como sendo a largura,

$$
F_{\text {max }}=F_{F M U S P} \cdot \frac{\pi d_{\text {medio }}}{5 \mathrm{~mm}}
$$

onde $F_{\max }$ denota a força máxima do teste aqui proposto, $F_{F M U S P}$ denota a força máxima encontrada pela equipe do Professor Doutor Erasmo Simão da Silva e $d_{\text {medior }}$ em milímetros, denota o diâmetro médio do subgrupo de aortas abdominais.

Na determinação da pressão máxima sobre os espécimes de aorta aneurismática, foi usada a equação (2.2) (página 27).

Chamam a atenção os valores de pressão e de tração de ruptura de aortas abdominais humanas saudáveis, muito superiores aos encontrados para as aneurismáticas. O valor apresentado na tabela 4.2 (página 50) foi calculado a partir da equação (2.2) e, tanto esse dado quanto os referentes à tensão de ruptura em teste de tração longitudinal, referem-se à aorta, saudável, de um indivíduo de 25 anos. A ordem de grandeza desses dados é confirmada [32].

A distância entre esses valores se deve ao fato de, com o passar dos anos, o tecido perder elasticidade, devido à diminuição de elastina e ao aumento do colágeno [18]. De fato, aneurismas não são comuns em pessoas jovens. A relação entre a variação do diâmetro aórtico e a pressão interna nesse vaso é função, dentre outros, do sexo e 
da idade, como mostra a figura 3.2, em que a diminuição da derivada da curva com o avanço da idade evidencia a redução da elasticidade do tecido.

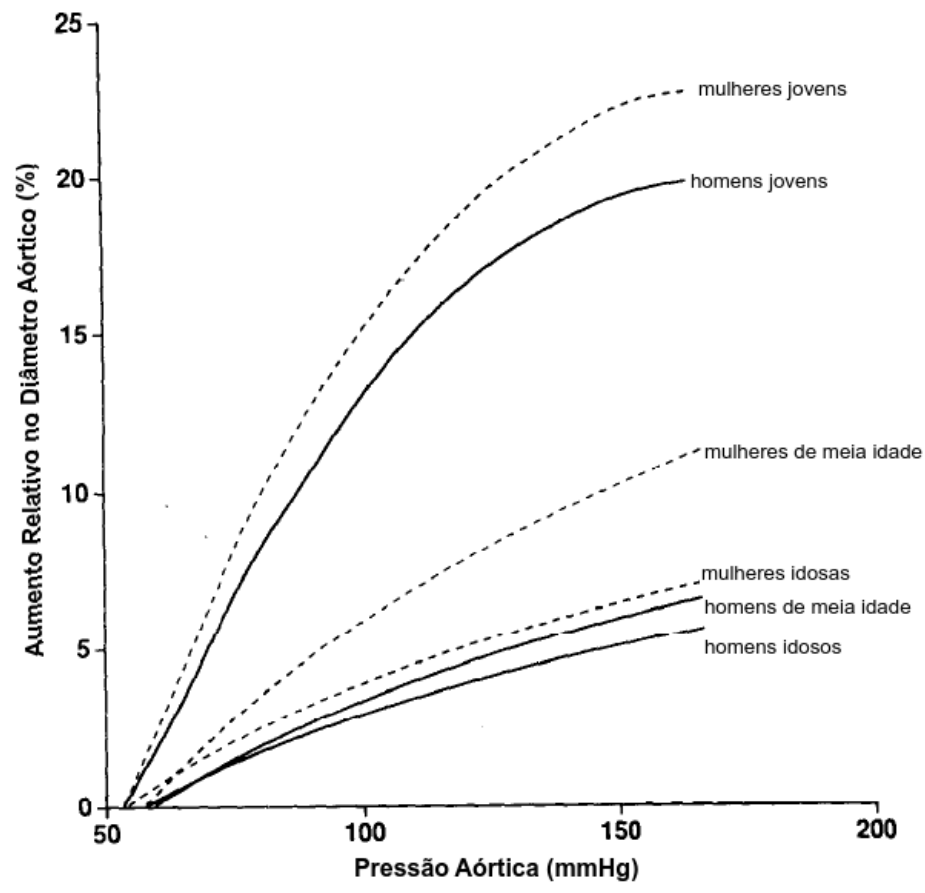

Figura 3.2: Influência do sexo e da idade na variação relativa do diâmetro aórtico, conforme a pressão interna. A figura evidencia a diminuição da elasticidade do tecido, o que pode ser observado pela diminuição da derivada da curva para pacientes de idade mais avançada. Extraído e adaptado [18]

\subsection{Descrição do equipamento de ensaio biaxial}

O equipamento é composto pelos subsistemas de tração longitudinal e de insuflamento. O primeiro pode ser expandido em estrutura em U, célula de carga, mesa linear, redutor, servomotor e servodrive. O segundo, por sua vez, consiste do compressor, da válvula reguladora de pressão, do tanque contendo o soro a ser injetado no espécime e do transdutor de pressão. Também fazem parte do equipamento, cuba de ensaios, garras, base e uma bomba para a manutenção da temperatura e para a circulação do líquido.

Cada uma dessas partes será abordada em maiores detalhes no capítulo 4.9(a). 


\subsection{Projeto do equipamento biaxial}

Foi definido um sistema independente de coordenadas para as membranas testadas. A coordenada $z$, longitudinalmente ao espécime, $r$, radial, e $\theta$, azimutal (figura 3.3). Podem-se exercer esforços na direção paralela à coordenada azimutal através do insuflamento do espécime, conforme será detalhado na seção 4.3.5. Longitudinalmente, o carregamento é aplicado através de um mecanismo de tração. Foram definidos e conduzidos 3 tipos de ensaios, tração longitudinal pura, insuflamento puro e tração com insuflamento, ou ensaio biaxial. Os parâmetros de teste podem ser modificados conforme a necessidade, através de software.

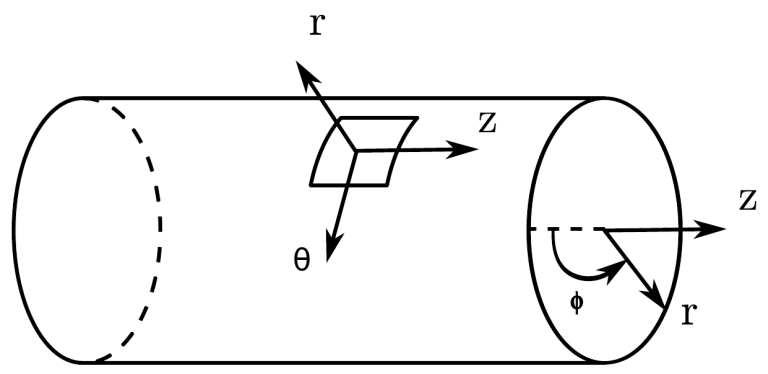

Figura 3.3: Diagrama de coordenadas no espécime. O carregamento na direção longitudinal se dá através de um mecanismo criado para impor tração nesse eixo, e o carregamento paralelo à coordenada azimutal $(\theta)$, através do insuflamento, para o qual foi criado um subsistema à parte.

\subsection{Construção do equipamento biaxial}

Foram listadas e analisadas as possíveis soluções para a realização dos testes biaxiais, sempre levando em conta a necessidade de se medirem os esforços aplicados e as deformações sofridas. Finalmente, o custo de cada uma dessas alternativas foi levado em conta, para que se definisse cada um dos subsistemas componentes do conjunto.

\subsection{Teste e calibração do equipamento}

Para a calibração dos subsistemas, foram realizados diversos ensaios de pré-condicionamento uniaxiais de tração longitudinal e de insuflamento com 
espécimes de pneu de bicicleta de espessura $1 \mathrm{~mm}$, seguindo ondas triangulares, conforme será detalhado na seção 4.4 .

A observação da filmagem dos testes mostrou ser possível determinar as variações de comprimento e de diâmetro, necessárias à caracterização dos tecidos.

O código, em linguagem de programação $C$, desenvolvido para o controle do equipamento, permite a modificação de qualquer dos parâmetros de teste, como o número de medições e de ciclos de pré-condicionamento, a frequência de coletas e o tempo de espera, bem como as pressões mínima e máxima. Também é possível testar espécimes de comprimentos iniciais variados, sendo os $100 \mathrm{~mm}$ mencionados apenas uma base para a criação das tabelas a serem apresentadas no capítulo 4.9(a). 


\section{Capítulo 4}

\section{Resultados e discussão}

Foi projetado, construído e testado um equipamento para a realização de testes biaxiais em espécimes de tecido mole, podendo-se auferir a força de tração e a pressão no interior dos espécimes. Ademais, a filmagem do teste através de 2 eixos ortogonais possibilitou a determinação das deformações axial e radial. Relações para estimar o estado de tensão podem ser apreciadas na literatura de Teoria da Elasticidade [33].

Conforme mencionado, os testes foram realizados com tecidos sintéticos. Um dos fatores cruciais do projeto foi a escolha das garras, de modo a promover a fixação dos espécimes, permitindo seu ensaio sem danos ao tecido. Para auxiliar na fixação, foram utilizados fios de sutura, conforme vem sendo feito em outros trabalhos [34], ou lacres plásticos. Foi observado, conforme será abordado no presente trabalho, que, para os espécimes empregados, os lacres plásticos resultaram em melhor fixação.

Dado que a força máxima a ser aplicada depende do tecido ou do órgão, é esperado que alguns espécimes sejam perdidos durante a aplicação da pré-carga, conforme descrito na literatura disponível sobre outros experimentos desse tipo, como os do HCFMUSP [1].

\subsection{Estimação dos dados não encontrados na bibliografia}

Conforme mencionado, as veias cavas inferior e superior (figuras 4.1(a) e 4.1(b) são responsáveis por levar todo o sangue, já pobre em $\mathrm{O}_{2}$, de volta para o coração. $\mathrm{O}$ sistema venoso, em geral, oferece uma elevada resistência ao fluxo de sangue, levando a uma diminuição da pressão sanguínea. Muitas forças externas agem sobre elas, razão 
pela qual ficam colapsadas uma boa parte do tempo [34]. Assim, para efeito de cálculo do volume a ser injetado durante o teste de insuflamento, o volume mínimo das veias cavas foi considerado nulo.

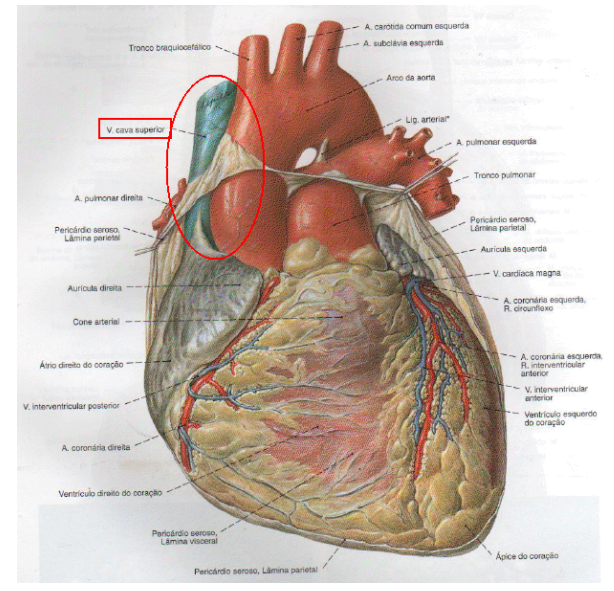

(a) Veia cava superior

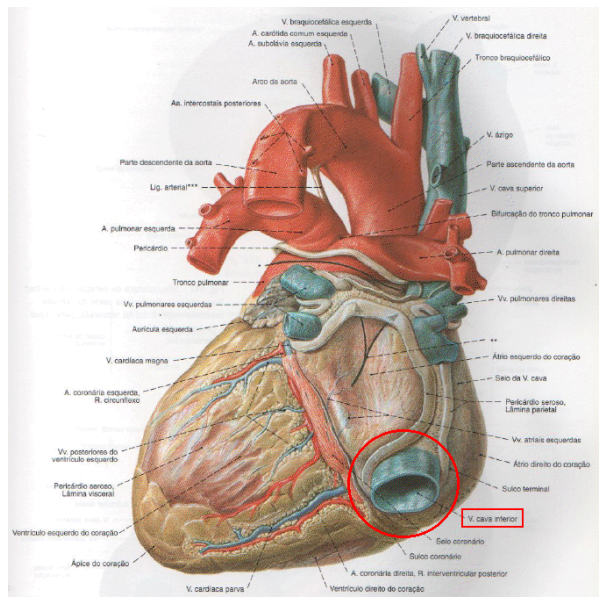

(b) Veia cava inferior

Figura 4.1: Vistas do coração humano, com as veias cavas superior e inferior evidenciadas em vermelho. Imagens extraídas e adaptadas [35].

A área de seção transversal máxima das veias cavas é de $400 \mathrm{~mm}^{2}$ cada uma [34]. Sua espessura pôde ser calculada, tendo sido encontrado o valor de $0,74 \mathrm{~mm}$ [36]. Na determinação do raio, foram usadas a variação do volume e a seção transversal média da veia cava, conforme a equação (4.1),

$$
r_{\max }=\sqrt{\frac{400}{\pi}}=11,287 \mathrm{~mm}
$$

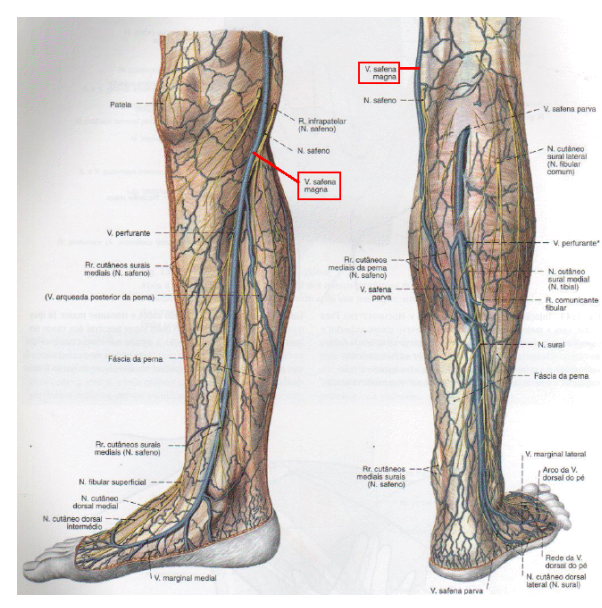

Figura 4.2: Safena magna. Extraído e adaptado [35] 
Quando a ligação entre a aorta e as artérias coronárias fica obstruída, realiza-se a cirurgia chamada ponte de safena, ou ponte aorto-coronária, ou cirurgia de revascularização miocárdica. Nesse procedimento, um segmento da veia safena, mostrada na figura 4.2, é retirado da perna do paciente e enxertado conforme a necessidade, refazendo a ligação. É uma cirurgia de extrema importância, já que as artérias coronárias são responsáveis pela irrigação e oxigenação do tecido cardíaco.

A grande importância das safenas justifica a necessidade de sua caracterização mecânica. A compreensão dessas características poderá viabilizar, no futuro, a criação de materiais protéticos para a realização da ponte de safena, dispensando a utilização de enxertos. Isso reduziria o risco atrelado ao processo atual, uma vez que menos procedimentos seriam realizados concomitantemente. Via de regra, os pacientes que recorrem a esse procedimento são idosos, o que, por si só, aumenta o seu risco cirúrgico.

São consideradas saudáveis para utilização em pontes aorto-coronárias safenas de diâmetro externo superior a $3 \mathrm{~mm}$ [34]. O presente trabalho considera a distensão longitudinal da veia safena como sendo a mesma da aorta saudável. Testes com safenas possibilitarão o refinamento desse valor.

A uretra masculina, por sua vez, é dividida em 4 partes: prostática, membranosa, bulbar e peniana. As duas primeiras compõem a uretra posterior, e as duas últimas, a anterior (figuras 4.3(a) $\mathrm{e} 4.3(\mathrm{~b})$ ).

A prostatectomia consiste na remoção de parte da próstata ou de toda ela, sendo esse um procedimento relativamente comum em homens de meia idade, normalmente em casos de tumores ou de hiperplasia benigna de próstata (HBP), que causa estreitamento da uretra, resultando em dificuldade de micção. Conforme mostra a figura 4.3(a), a próstata envolve a parte prostática da uretra. Sua retirada leva à diminuição da pressão externa sobre o tecido uretral que, em até $25 \%$ das vezes [37], passa a permitir a passagem de urina contra a vontade do paciente [38]. Entender a distribuição radial de tensões sobre o tecido uretral pode ser a chave para contornar esse problema que, apesar de não levar à morte, reduz drasticamente a qualidade de vida do paciente. 


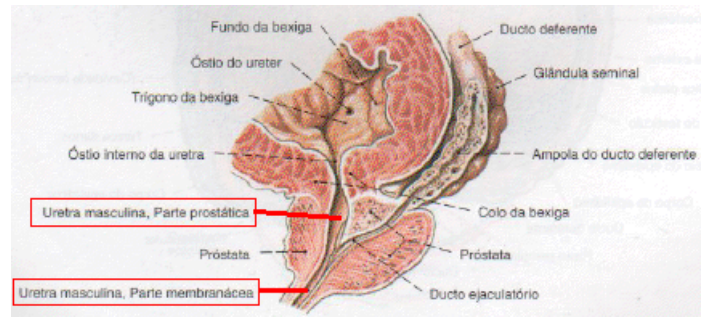

(a) Uretra posterior

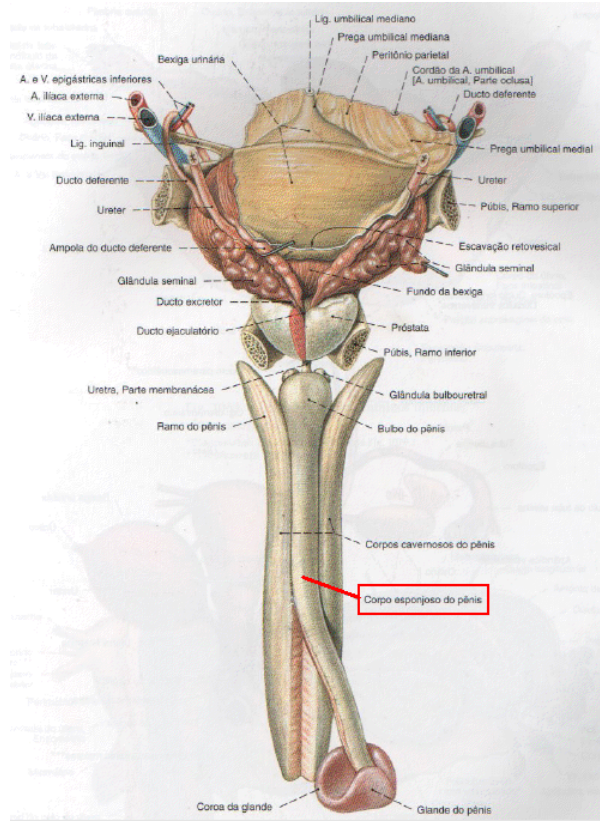

(b) Uretra anterior

Figura 4.3: A uretra masculina. Imagens extraídas e adaptadas [35].

Na ausência de fluxo urinário, o canal uretral se fecha, tornando-se nada mais que um canal virtual [38]. Por isso, considerou-se como nulo o seu volume interno de repouso.

Não foram encontrados, na literatura, testes de tração ou de insuflamento, até a ruptura, em uretras masculinas. Na impossibilidade de se obterem tais dados, optou-se por considerar o diâmetro interno máximo da uretra como aquele assumido durante o exame de cistoscopia, ou seja, o diâmetro do cistoscópio, de $10 \mathrm{~mm}$.

O esôfago humano (figura 4.4) tem comprimento de até $260 \mathrm{~mm}$ e fica, normalmente, fechado. Na presença de alimento, assume um formato externo máximo aproximadamente elíptico por onde esse alimento passa, de aproximadamente $20 \mathrm{~mm}$ na direção antero-posterior, e de $30 \mathrm{~mm}$ lateralmente [39]. Não foi encontrada, na literatura, qualquer informação sobre a pressão necessária para se imprimir qualquer distensão transversal ao esôfago, razão pela qual este órgão não foi adicionado à figura 4.7. Além disso, as dimensões apresentadas sobre o esôfago referem-se a condições fisiológicas, e não à ruptura. 


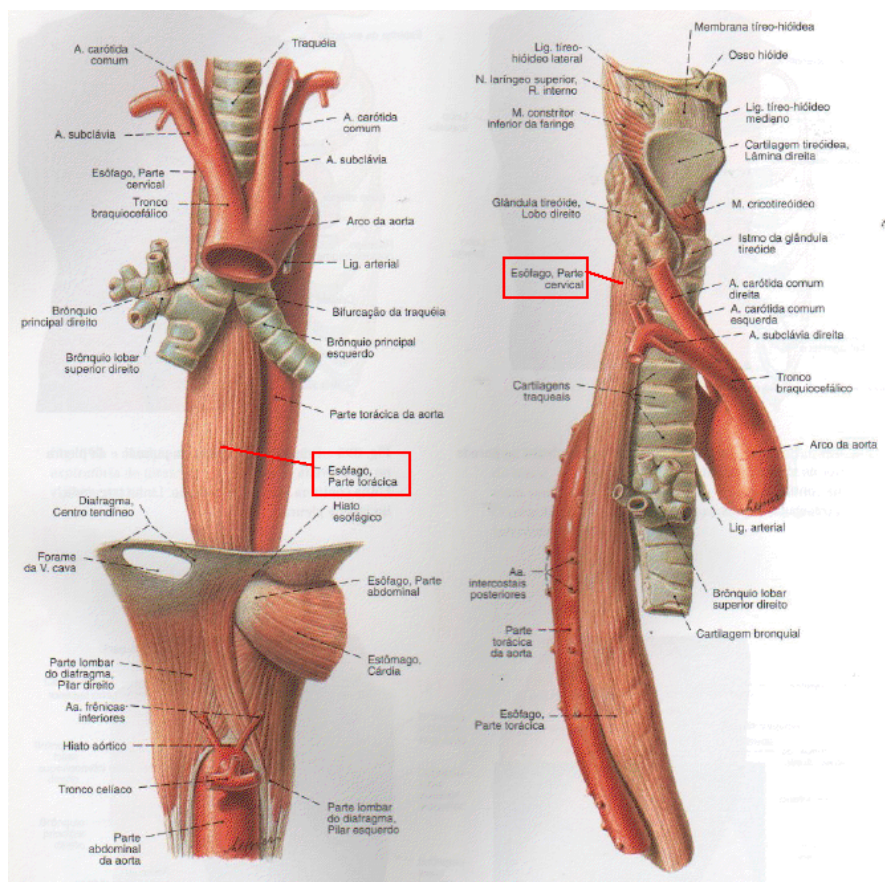

Figura 4.4: Esôfago humano. Extraído e adaptado [35]

Também será possível estudar espécimes de intestino delgado humano (figura 4.5). Em testes realizados em porcos, histologicamente semelhantes aos humanos [38], foi imposta tração longitudinal de $40 \mathrm{~N}$ por metro de largura [40]. Considerando esse dado também para humanos, uma força de 6,029 N foi usada para encontrar a tensão longitudinal aplicada ao espécime, resultando em uma tensão de 42, $96 \mathrm{kPa}$.

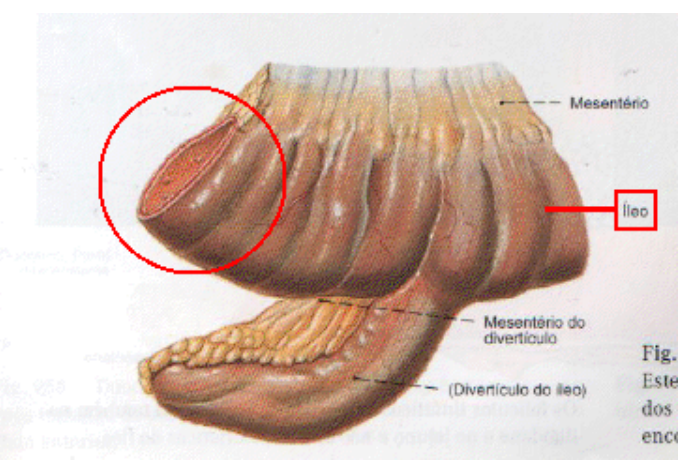

(a) O íleo

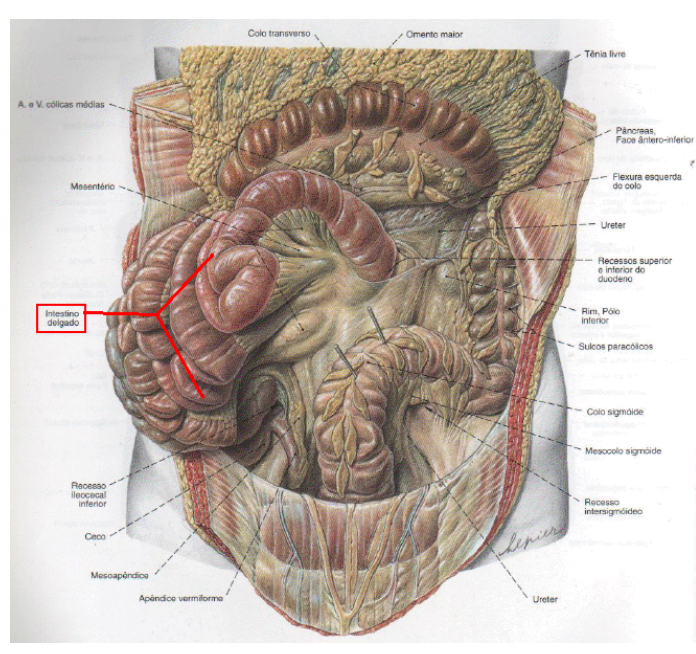

(b) O intestino delgado

Figura 4.5: O intestino delgado humano. Imagens extraídas e adaptadas [35]

O último órgão apresentado para o estudo é o intestino grosso (figura 4.6). 


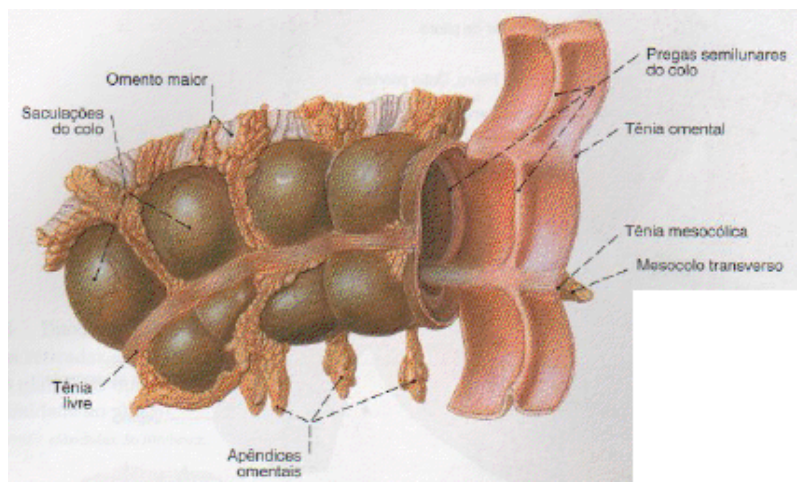

Figura 4.6: Colo transverso do intestino grosso humano. Fonte: [35]

As tabelas 4.1 e 4.2 reúnem os dados encontrados e calculados, relevantes para o dimensionamento dos componentes dos subsistemas de tração longitudinal e de insuflamento dos espécimes. 
Tabela 4.1: Parâmetros para testes de diferentes órgãos geometricamente convexos. Dados relevantes para o teste de tração

\begin{tabular}{|c|c|c|c|c|c|c|c|c|}
\hline Órgão/caso & $\begin{array}{l}L_{0} \\
(\mathrm{~mm})\end{array}$ & $\begin{array}{l}L_{\max } \\
(\mathrm{mm})\end{array}$ & $\begin{array}{l}F_{\text {rupt }} \\
(\mathrm{N})\end{array}$ & $\begin{array}{l}\sigma_{\text {rupt }} \\
(\mathrm{kPa})\end{array}$ & $\begin{array}{l}\epsilon_{\text {rupt }}^{\text {long }} \\
(\%)\end{array}$ & $\begin{array}{l}d_{0} \\
(\mathrm{~mm})\end{array}$ & $\begin{array}{l}d_{\max } \\
(\mathrm{mm})\end{array}$ & $\begin{array}{l}\mathrm{t} \\
(\mathrm{mm})\end{array}$ \\
\hline AAA $120 \mathrm{~mm}^{a}$ & 100 & 142,5 & 381,634 & 65,573 & 0,4249 & 120 & 170,99 & 1,57 \\
\hline AAA $100 \mathrm{~mm}^{a}$ & 100 & 136 & 437,820 & 75,945 & 0,3596 & 100 & 135,96 & 1,55 \\
\hline AAA $89 \mathrm{~mm}^{a}$ & 100 & 138,4 & 314,181 & 57,411 & 0,3838 & 89 & 123,16 & 1,47 \\
\hline AAA $70 \mathrm{~mm}^{a}$ & 100 & 141,6 & 226,719 & 38,04 & 0,4159 & 70 & 99,12 & 1,60 \\
\hline AAA $54 \mathrm{~mm}^{a}$ & 100 & 139,8 & 162,175 & 27,333 & 0,3979 & 54 & 75,48 & 1,60 \\
\hline AAA $38 \mathrm{~mm}^{a}$ & 100 & 122,6 & 38,068 & 8,551 & 0,2262 & 38 & 46,60 & 1,19 \\
\hline AA saudável ${ }^{a b}$ & 100 & 185 & 183,821 & 2200 & 0,9 & 20 & 38 & 1,43 \\
\hline Aorta suína ${ }^{c d}$ & 40 & 60 & 28,413 & 500 & 0,5 & 20 & 30 & 0,95 \\
\hline Cava humana $^{e}$ & 100 & 184 & 59,578 & 1174,37 & 0,84 & 22,57 & 34,09 & 0,74 \\
\hline Safena humana ${ }^{e f}$ & 100 & 170 & & & 0,7 & 3 & 10,2 & \\
\hline Uretra $^{g}$ & 100 & 300 & & & 2 & 10 & 10 & 5 \\
\hline Esôfago humano ${ }^{h}$ & 100 & 240 & 208,173 & 1200 & 1,4 & 25 & 25 & 2,45 \\
\hline Int delgado humano $^{h i}$ & 100 & 245 & 6,029 & 42,955 & 1,4500 & 48 & 48 & 0,95 \\
\hline Int grosso humano ${ }^{h}$ & 50 & 152,5 & 202,613 & 1200 & 2,05 & 60 & 60 & 0,91 \\
\hline
\end{tabular}

\footnotetext{
${ }^{a}$ Fonte: [1]

${ }^{b}$ Fonte: [41, 32]

${ }^{c}$ Fonte: 42

${ }^{d}$ Fonte: 43

${ }^{e}$ Fonte: [34]

${ }^{f}$ Fonte: [44]

${ }^{g}$ Fonte: [45]

${ }^{h}$ Fonte: [46]

${ }^{i}$ Fonte: [40]

${ }^{j}$ Fonte: imagens de tomografia cedidas pela FMUSP

${ }^{k}$ Fonte: 47]
} 


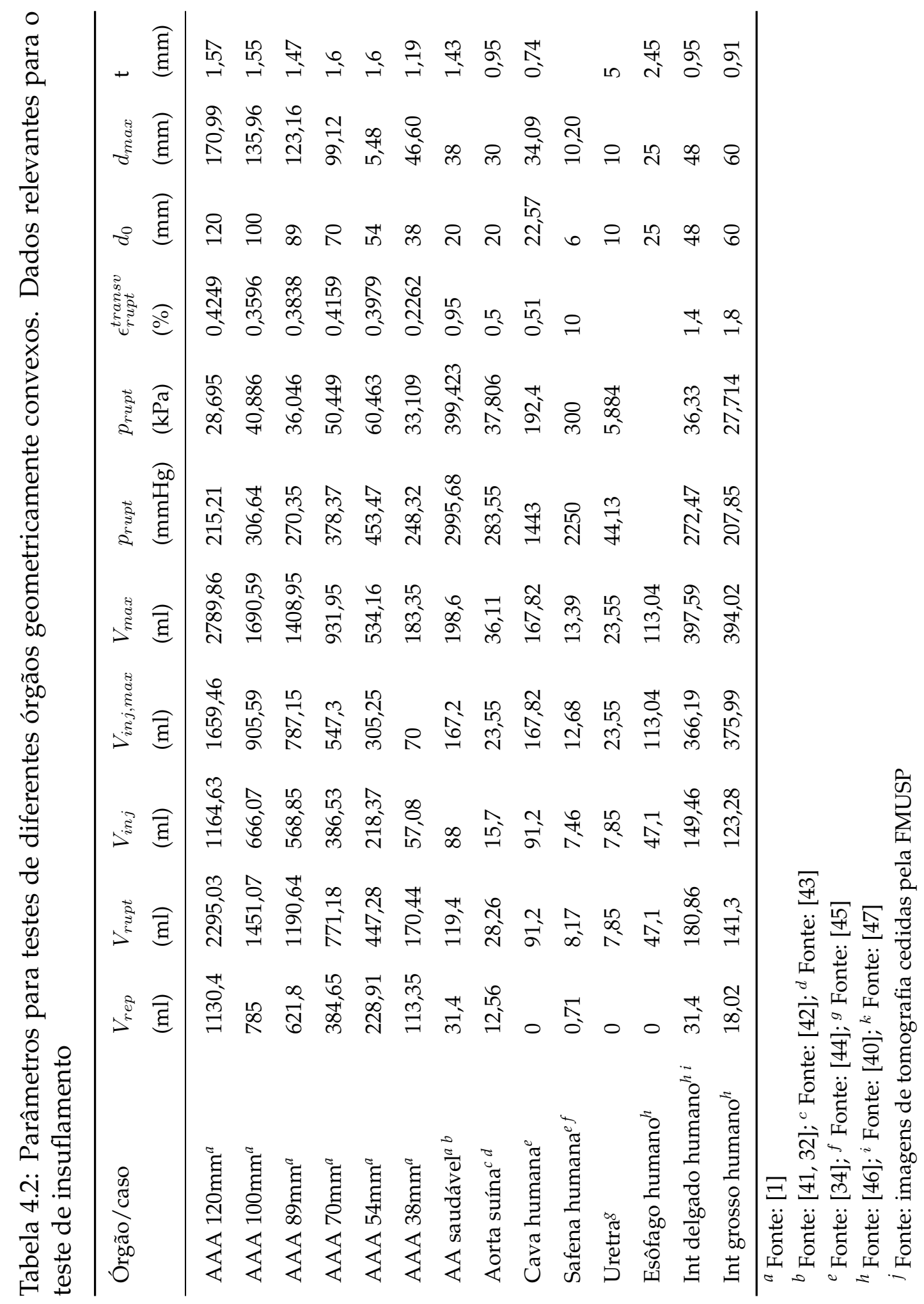


O gráfico da figura 4.7 mostra os volumes mínimo e máximo esperados, em $\mathrm{ml}$, para cada tecido ou órgão estudado, bem como a pressão de ruptura, em $k P a$. Nele, $V_{i n j}$ pode ser calculado pelo comprimento, na horizontal, da linha correspondente a cada órgão estudado.

Chama a atenção a distância entre as pressões de ruptura de aortas saudáveis e de aortas aneurismáticas, conforme já explicado.

Da mesma forma, o gráfico da figura 4.8 mostra a deformação percentual esperada para cada tecido ou órgão, plotado em um gráfico em que a ordenada representa a força máxima, em $N$, que se espera impor a ele.

Nota-se que a elongação máxima esperada para aortas saudáveis é bem superior à esperada para as aneurismáticas. 


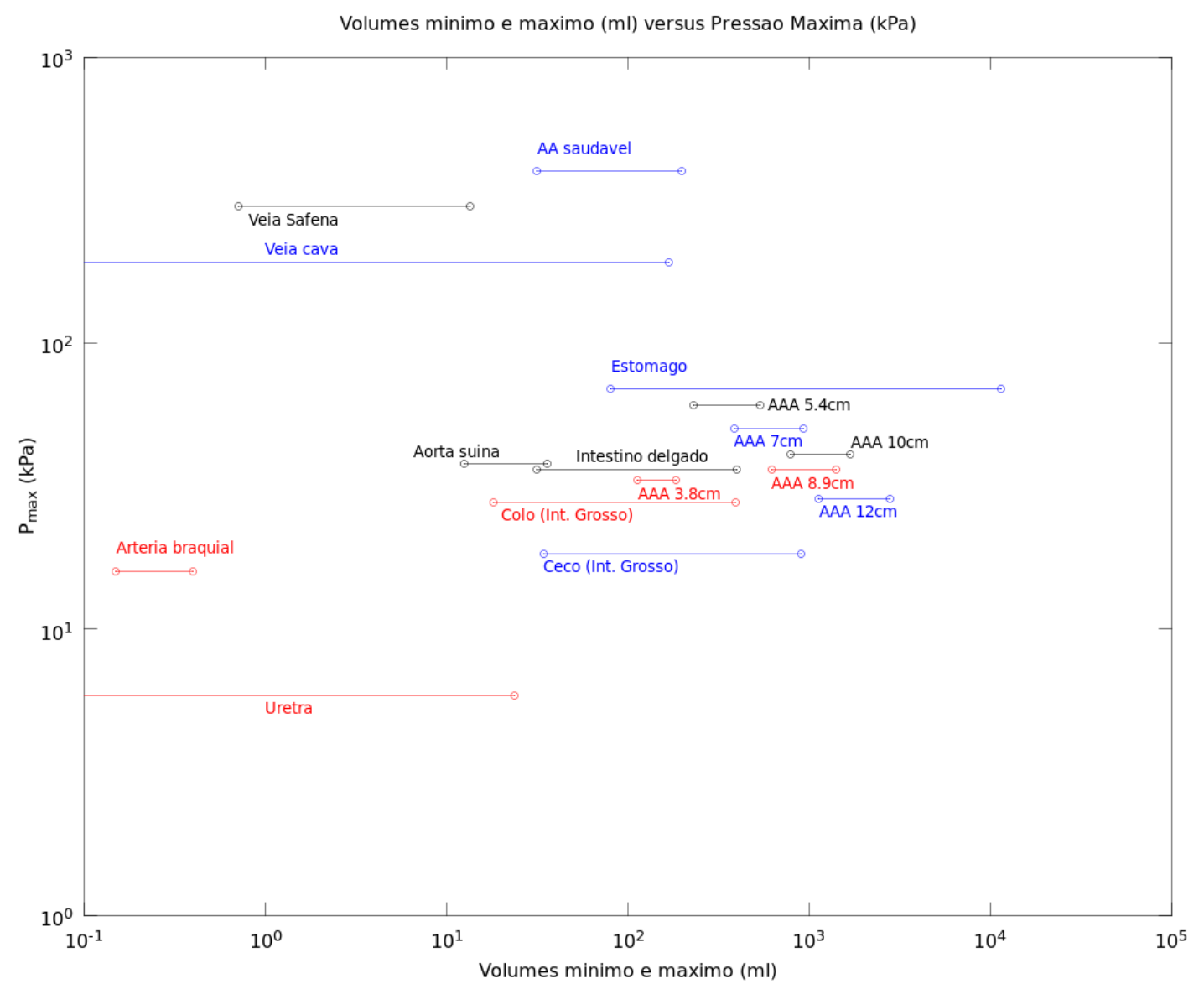

Figura 4.7: Gráfico de dispersão, gerado através das tabelas 4.1 e 4.2 (páginas 49 e 50), dos logaritmos dos volumes inicial e máximo, pelo logaritmo da pressão máxima. Atenção à distância entre as pressões de ruptura de aortas saudáveis e de aortas aneurismáticas. 


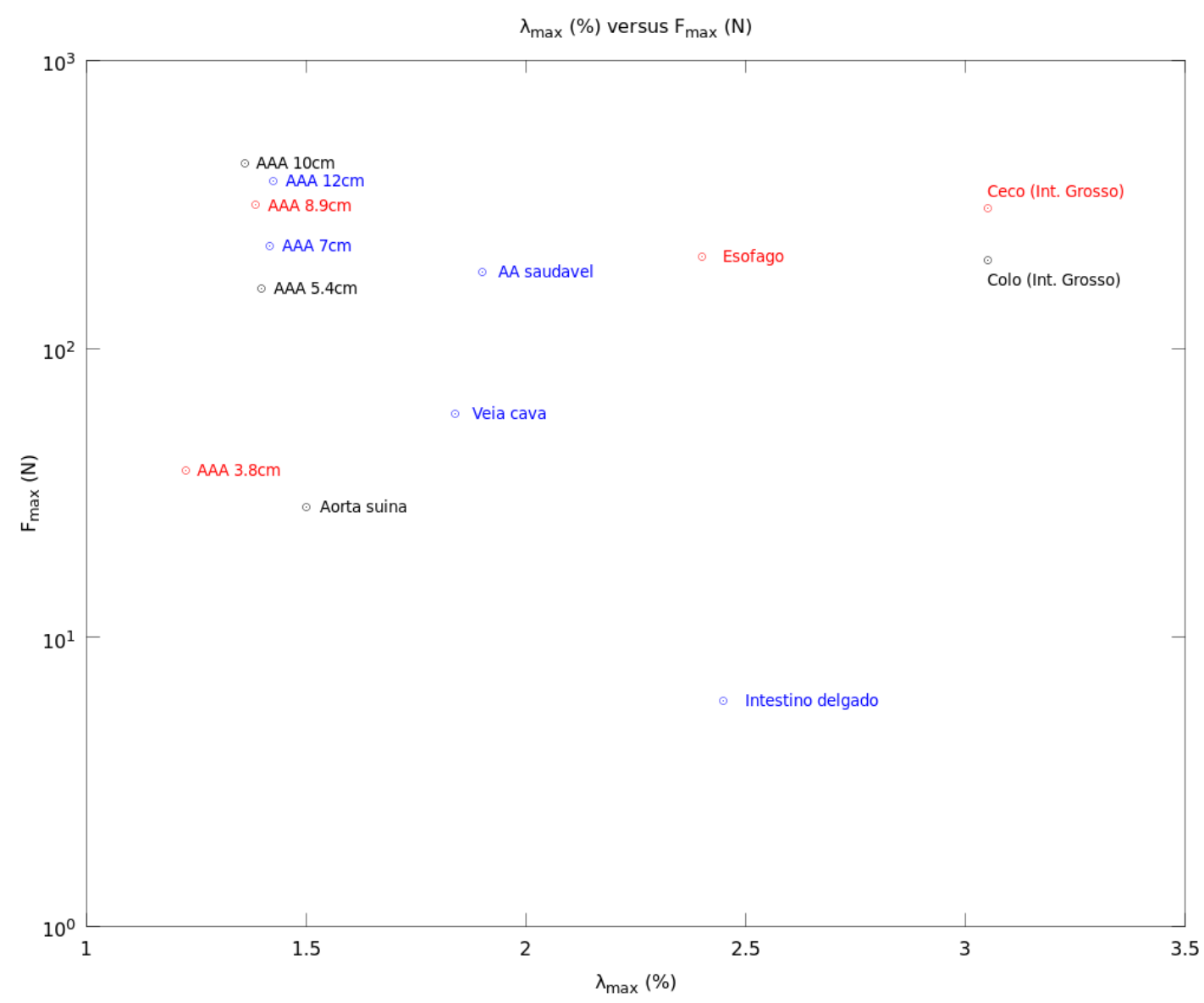

Figura 4.8: Gráfico de dispersão, gerado através das tabelas 4.1 e 4.2 (páginas $49 \mathrm{e} 50$ ), da elongação máxima pelo logaritmo da força máxima. Atenção à elongação máxima de aortas saudáveis, bem superior à das aneurismáticas.

\subsection{Descrição do equipamento biaxial}

Para se referir às partes e aos subsistemas do equipamento, foi definido um sistema de coordenadas composto pelos seguintes eixos: $x$, horizontal, paralelo à direção longitudinal do espécime, positivo para a direita, $y$, paralelo à direção vertical, positivo para cima, e $z$, também horizontal, perpendicular ao eixo longitudinal do espécime.

Para garantir a qualidade dos resultados, nenhum espécime poderá ter sido congelado ou submetido a conservantes como formol, devendo, portanto, vir de cadáveres frescos, não mais de 48 horas após a dissecção [10]. Também é necessário que, durante todo o teste, nenhuma parte do tecido encoste nas laterais da cuba, evitando, dessa forma, distorção nos resultados. Dado que os tecidos retirados 
de cadáveres nem sempre estarão íntegros ao longo de todo o seu comprimento, também será possível testar espécimes partindo de comprimentos menores, conforme mencionado anteriormente.

Assim sendo, e conforme os dados obtidos e apresentados nas tabelas 4.1

e 4.2. foram adotadas, para o equipamento, as seguintes especificações: força máxima de tração: $500 \mathrm{~N}$; pressão interna máxima a ser imposta aos espécimes: $500 \mathrm{kPa}$; comprimento inicial do menor espécime, descontando-se o comprimento da região de fixação: $20 \mathrm{~mm}$; dimensão longitudinal máxima, incluindo deformação: $400 \mathrm{~mm}$; diâmetro máximo sob insuflamento: $200 \mathrm{~mm}$; velocidades de tração para os comprimentos iniciais previstos: de 4 a $20 \mathrm{~mm} / \mathrm{min}$, podendo atingir velocidades lineares maiores ou menores; temperatura de operação: $37^{\circ} \mathrm{C}$; e nível do líquido no banho: $240 \mathrm{~mm}$.

\subsection{Projeto e construção do equipamento biaxial}

Dada a necessidade de se testar uma ampla variedade de espécimes em termos de forças e pressões aplicáveis, assim como em termos de dimensões iniciais e finais, o equipamento foi projetado de modo a comportar qualquer um deles, do menor ao maior, assim como as deformações possíveis. No presente capítulo, os desenhos técnicos apresentados foram confeccionados com o auxílio dos softwares livres Draftsight e Inkscape.

A ampla variedade de características físicas dos tecidos e órgãos a serem caracterizados contribuiu para que se decidisse por separar o equipamento em módulos substituíveis. Levando em consideração o amplo espectro de diâmetros iniciais, uma das partes cuja separação foi necessária foram as garras para a fixação dos espécimes.

\subsubsection{Garras}

Foi definido que o insuflamento dar-se-ia pelo lado esquerdo dos espécimes, por razões a serem explicadas em maiores detalhes na seção 4.3.4. Portanto, foi definido que a garra da esquerda conteria um furo passante. Nessa mesma extremidade, um outro furo, de rosca $0,25 i n-18$, permitiria sua conexão a um engate rápido, ao qual fixar-se-ia 
um tubo de poliuretano de diâmetro $6 \mathrm{~mm}$, capaz de suportar pressões internas de até $1000 \mathrm{kPa}$. Outra rosca, externa, $M 20 \times 2$, 5, garantiria a fixação dessa garra a uma chapa, a ser descrita na seção 4.3.3. A garra da direita, por sua vez, não teria esses furos. Uma rosca $M 16$ x 1, 5 garantiria sua conexão, conforme será detalhado na presente seção, a uma estrutura em $U$, a ser detalhada na seção 4.3.2.

A figura 4.9 mostra o projeto das garras para o ensaio dos espécimes de diâmetro inicial $20 \mathrm{~mm}$, como as aortas saudáveis. Foram evitados cantos vivos nas regiões de contato com os espécimes, para minimizar concentrações de tensões, o que aumentaria a probabilidade de ocorrerem rupturas na região de fixação, invalidando os testes em que isso viesse a ocorrer.

Uma das variáveis de definição mais delicada foi o ângulo ao lado direito da figura 4.9. O valor de $10^{\circ}$ foi adotado por facilitar a fixação do espécime, durante a qual não poderia haver sobra de qualquer dos materiais, devendo ser um encaixe justo. Se, ao ser fixado, o perímetro da seção transversal do espécime fosse maior que o da seção transversal da garra, haveria sobreposição de tecido, facilitando vazamentos e, assim, impossibilitando o teste de insuflamento. Por outro lado, se o perímetro da seção transversal da garra fosse maior que o da seção transversal do espécime, o encaixe, por ser forçado, introduziria pré-tensões, aumentando a probabilidade de ruptura naquela região, inclusive no momento do encaixe.

Assim, foi adotado um ângulo pequeno, garantindo que a diferença entre os perímetros das seções transversais dos diferentes picos nas garras fosse pequena, permitindo a acomodação de espécimes de diâmetros bem próximos. Ângulos maiores foram testados, constatando-se que, durante testes de insuflamento, a extremidade dos espécimes fixados a elas tendiam a se soltar mais facilmente. Por outro lado, ângulos ainda menores dificultariam a fixação do espécime, aumentando probabilidade de ruptura durante esse processo. 


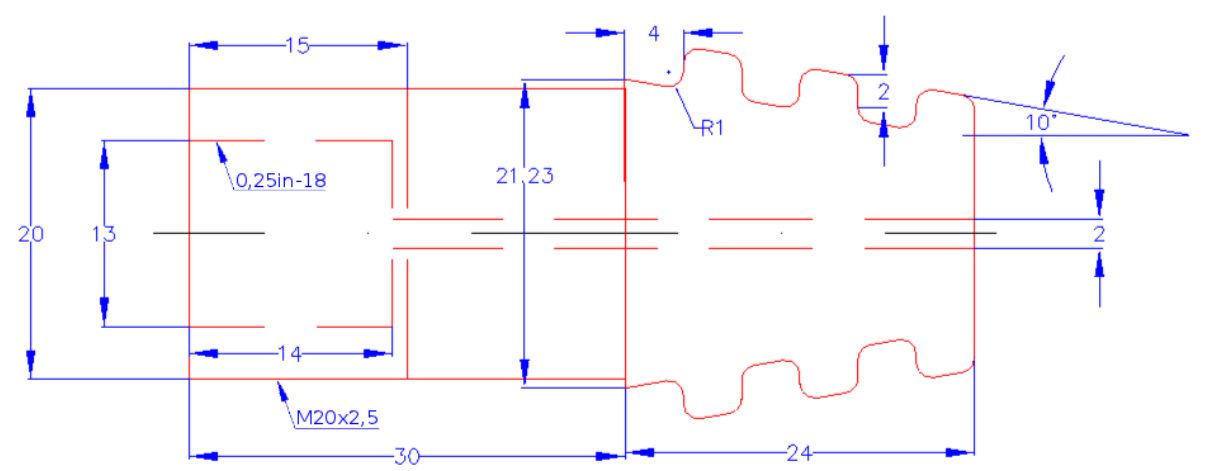

(a) Garra da esquerda. Atenção especial para o furo passante, necessário para permitir a troca de solução fisiológica entre o tanque e o espécime. A rosca interna, $0,25 i n-18$, garante conexão ao engate rápido para a troca desse líquido, e a rosca externa, $M 20 \times 2,5$, permite conexão à chapa, a ser descrita na seção 4.3 .3 O espécime é fixado, conforme explicado na seção, com lacres plásticos ou fio de sutura, aos picos da parte da direita da garra.

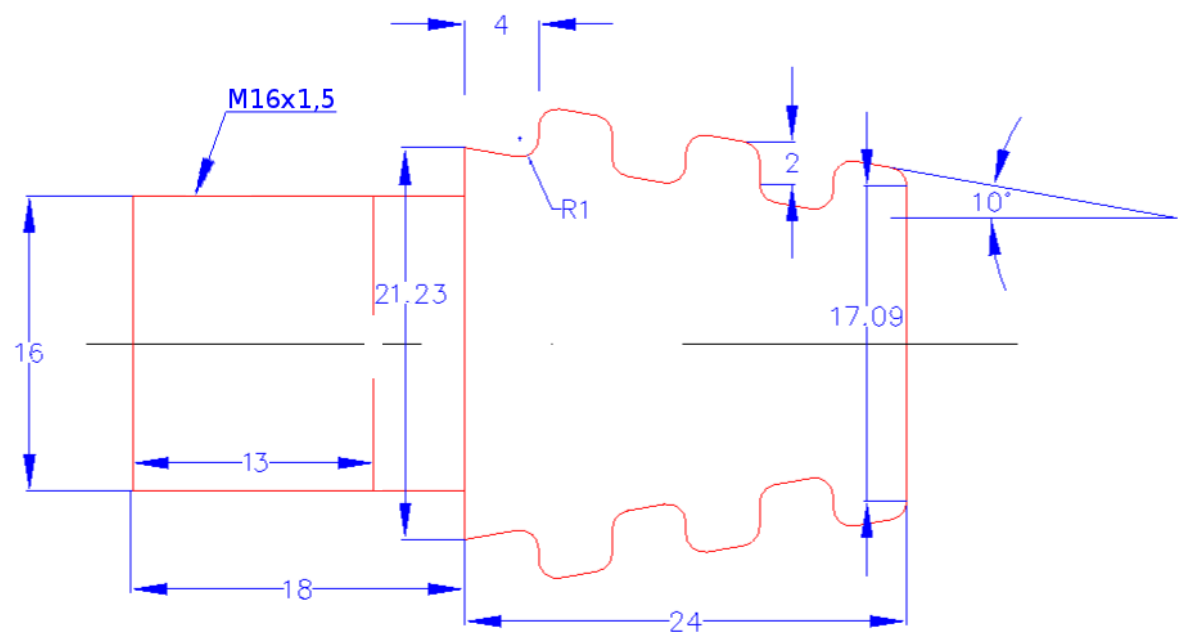

(b) Garra da direita. Esta garra não contém o furo passante, nem a rosca interna, uma vez que não há troca de líquidos através dela. Conta apenas com uma rosca $M 16 \times 1,5$ para a fixação à peça cujo projeto é apresentado na figura 4.11 que, por sua vez, é parafusada estrutura em $\mathrm{U}$, a ser detalhada na seção 4.3.2 A região de fixação do espécime pode ser visualizada na parte direita da figura.

Figura 4.9: Garras para a fixação de espécimes de diâmetro inicial $20 \mathrm{~mm}$, como as aortas humanas saudáveis

A figura 4.10, cedida pelo Professor Doutor Erasmo Simão da Silva, evidencia a localização mais comum de AAAs, na região da bifurcação para as ilíacas. Por isso, foi criada uma adaptação, em alumínio, cujo projeto pode ser apreciado na figura 4.11 . 
A peça conta com 3 furos passantes. O central é preso à estrutura em U, por meio de parafuso $M 16 \times 1,5$, porca e arruela, e aos outros 2 furos são presas, com as mesmas porcas e arruelas, as garras mostradas na figura 4.9(b). O alinhamento é essencial para evitar distorções nas medições com a célula de carga, conforme será abordado em maiores detalhes no presente capítulo.

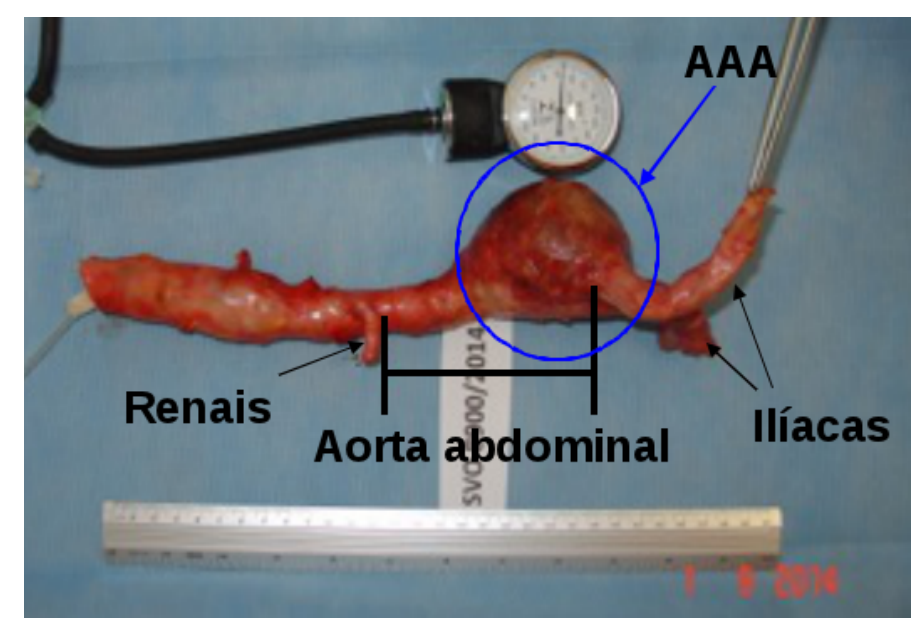

Figura 4.10: Localização mais comum de AAAs, na bifurcação para as ilíacas. Imagem concedida e uso autorizado pelo Professor Doutor Erasmo Simão da Silva.

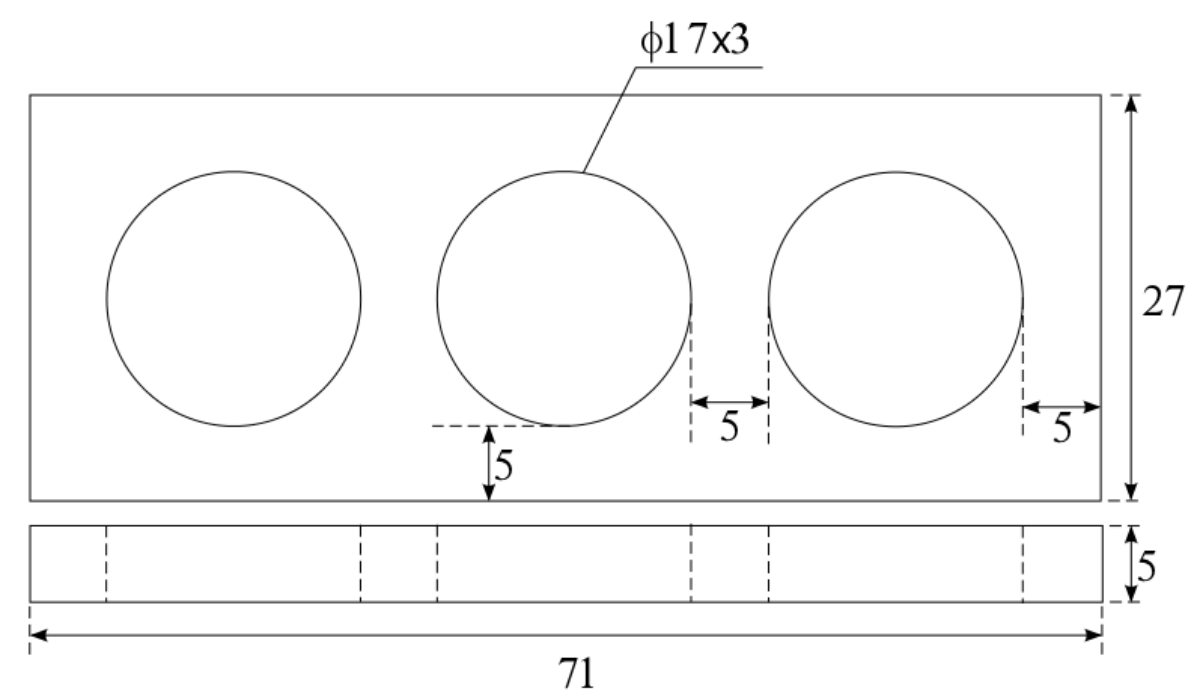

Figura 4.11: Adaptação para a fixação de AAAs ao equipamento de testes apresentado. $\mathrm{O}$ furo central serve para sua fixação à estrutura em $\mathrm{U}$, por meio de parafuso $M 16 \mathrm{x}$ 1,5 , porca e arruela. As mesmas porcas e arruelas fixam, a esta adaptação, as garras da direita, através dos outros 2 furos (projeto apresentado na figura 4.9(b)). O alinhamento do centro dos 3 furos garante a qualidade das medições com a célula de carga. 


\subsubsection{Estrutura em U}

Foi projetada e construída uma estrutura em U, de seção transversal também em U (figura 4.12), com a função de transmitir força axial ao espécime, além de manter a posição da extremidade direita dos espécimes, em relação à célula de carga, fixa ou facilmente calculável.

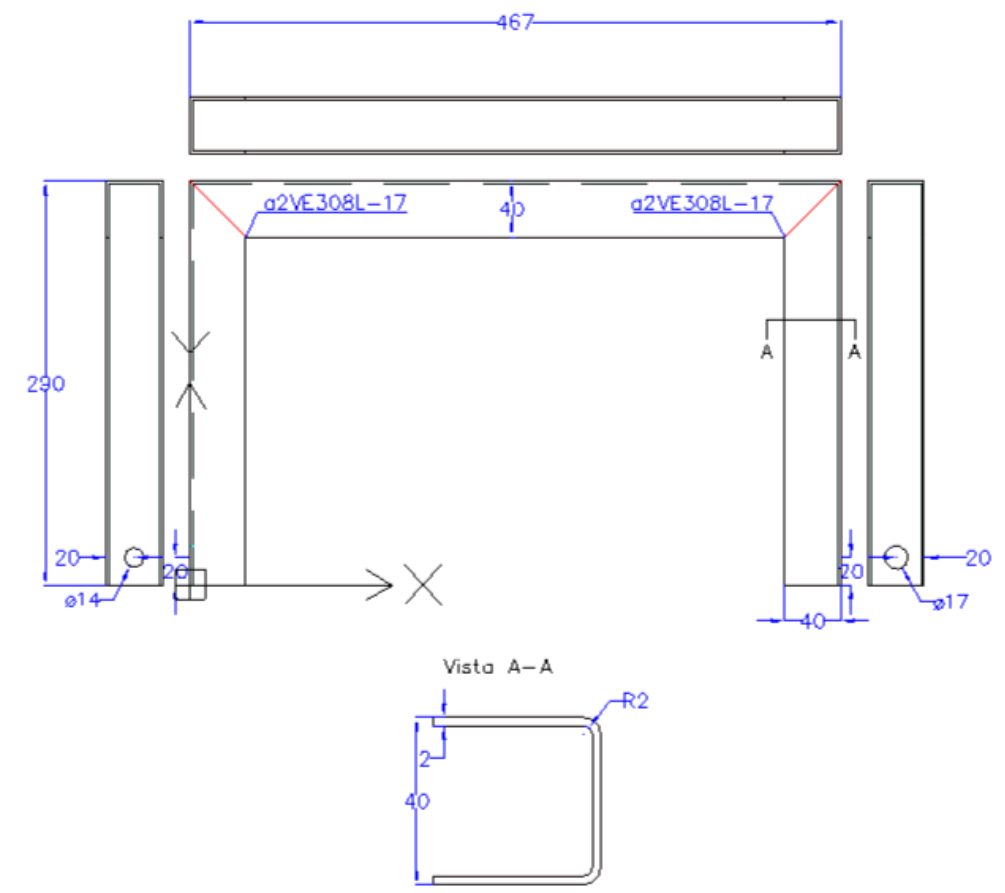

Figura 4.12: Projeto da estrutura em U

Os cuidados no projeto incluíram a preocupação com deformações plásticas da estrutura durante os testes, portanto, o material procurado precisaria apresentar uma elevada tensão de escoamento. Além disso, foi priorizado um elevado módulo de Young, já que, se baixo, haveria a necessidade de uma base e de uma mesa linear mais compridas, elevando o custo do projeto, a massa total do sistema e o tamanho do equipamento. Por fim, como o meio do ensaio poderia promover corrosão do material, foi escolhido o aço inox, liga 304.

Se a massa da estrutura em $U$ fosse muito alta, a célula de carga poderia ser danificada. Assim, foi adotada uma célula de carga que suportasse cargas laterais de até $500 \mathrm{~N}$. A figura 4.13 mostra a seção transversal calculada, de modo iterativo, para a estrutura em U. 


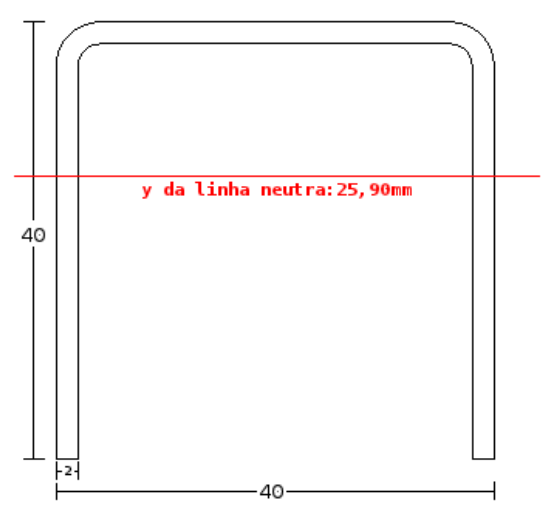

Figura 4.13: Perfil da seção transversal, determinado de modo iterativo

Conforme mostra a figura 4.14, os esforços sobre a estrutura em U atuariam na direção $x$ do equipamento. Também foi possível considerar o esforço total atuante sobre a estrutura em U como a soma de um momento a uma tração. O momento máximo ocorre na parte superior, com braço máximo de $270 \mathrm{~mm}$. Sendo o valor máximo da força $500 \mathrm{~N}$, o momento máximo resultante seria de $135 \mathrm{Nm}$.

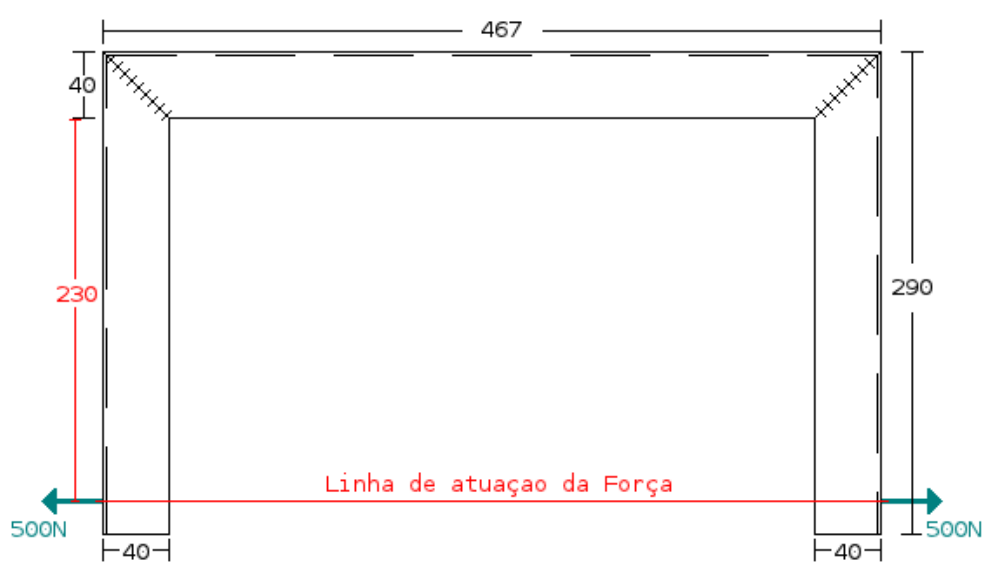

Figura 4.14: Medidas relevantes da estrutura em U para o cálculo da solda indicada

A análise da seção transversal dessa estrutura mostra que o momento de área, $I_{x}$, é $39282,85 \mathrm{~mm}^{4}$, e a altura da linha neutra, $y_{L N}$, é $25,90 \mathrm{~mm}$. De posse desses valores, a tensão gerada pelo momento foi calculada por meio da equação (4.2),

$$
\sigma_{\max }=\left|M_{\max }\right| \frac{y_{L N}}{I_{x}}
$$

onde $\left|M_{\max }\right|$ denota o maior momento fletor, em módulo, $y_{L N}$ denota a maior distância 
entre fibras do material e a linha neutra, e $I_{x}$ denota o momento de área.

Assim, a tensão gerada pelo momento fletor é de 89,01 MPa. A gerada pela tração, por sua vez, pode ser obtida por meio da equação (3.5), e resulta em 2,16 MPa, totalizando 91, $17 \mathrm{MPa}$ de tensão máxima na parte superior, sendo 2,37\% dela causada pela tração, e 97,63\% causada pelo momento fletor, composição essa que dispensa a investigação de tensões geradas sobre as outras partes dessa estrutura. O ponto da solda sob maior solicitação é o mais alto da estrutura em U.

Considerando a mínima tensão de escoamento do aço como sendo igual a $170 \mathrm{MPa}$ e que, na região de solda, tem-se $70 \%$ da resistência do material [48], o fator de segurança é 1,31 .

A partir dos valores de tensão calculados, foi dimensionada uma solda bicelada (figura 4.15(a)), de espessura $a$, conforme calculado a seguir.

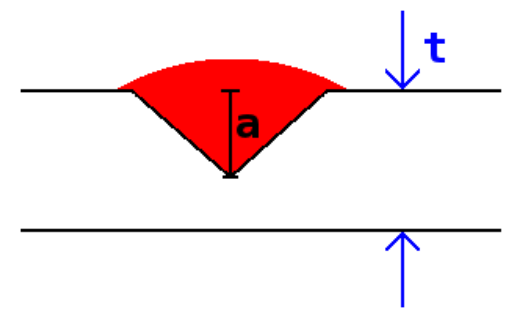

(a) Solda bicelada

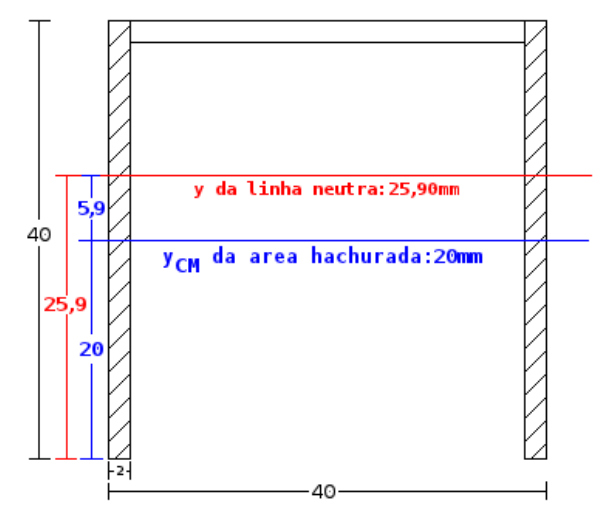

(b) Perfil da seção transversal

Figura 4.15: Cálculo da solda da estrutura em U

Voltando à seção transversal dessa estrutura, onde a solda foi depositada, o momento de área da solda na região hachurada da figura 4.15(b), com relação ao próprio baricentro, é $I^{\prime}=10666,67 . a$. Pelo Teorema de Steiner, com relação à linha neutra da seção transversal,

$$
\begin{aligned}
& I=I^{\prime}+d^{2} \cdot[\text { Area }] \\
& I=10666,67 \cdot a+(5,90)^{2}(2 . a \cdot 40) \\
& I=13451,47 \cdot a,
\end{aligned}
$$


onde $d$ denota a distância entre os eixos paralelos, e o multiplicador 2 aparece em decorrência de se estarem transferindo os momentos das área das duas abas.

Assim, a tensão gerada sobre esse perfil pelo momento $M$ pode ser calculada pela equação 4.4 .

$$
\sigma_{M}=\frac{M \cdot y_{L N}}{I}=\frac{259,93}{a}
$$

A tensão gerada pela tração, por sua vez, é obtida pela equação (3.5),

$$
\sigma_{T}=\frac{500}{2.40 \cdot a}=\frac{6,25}{a}
$$

Assim, a tensão total gerada sobre a solda é $\sigma_{\text {Total }}=\frac{266,18}{a}$, cujo resultado, com $a$ em $m m$, é dado em $\frac{N}{m m^{2}}$, ou $M P a$. Essa tensão, porém, é aplicada sobre um perfil inclinado em $45^{\circ}$, e pode ser decomposta em uma parcela normal, $\sigma_{N}$, e outra de cisalhamento, $\tau$. Dada a geometria, pode-se afirmar que,

$$
\begin{aligned}
\sigma_{N} & =\tau=\sigma_{\text {Total }} \cdot \frac{\sqrt{2}}{2} \\
\sigma_{N} & =\frac{188,22}{a} .
\end{aligned}
$$

Como não há tensões no eixo $z$ (perpendicular ao papel), pode-se considerar estado duplo de tensão, o que, aliado à equação 4.5 , permite o seguinte raciocínio,

$$
\begin{aligned}
& \sigma_{V M}^{2}=\sigma_{N}^{2}+3 \tau^{2} \\
& \sigma_{V M}^{2}=4 \sigma_{N}^{2} \\
& \sigma_{V M}=2 \sigma_{N}=\frac{376,44}{a} .
\end{aligned}
$$

O fator de concentração de tensão em soldas biceladas é $k_{T}=1,2$, levando a nova tensão de Von Mises a $\sigma_{V M}^{\prime}=\sigma_{V M} \cdot k_{T}=\frac{451.73}{a}$. Esse novo valor deve ser menor ou igual à tensão limite da solda $\left(\sigma_{y}\right)$, considerando um fator de segurança, FS,

$$
\sigma_{V M}^{\prime} \leq \frac{\sigma_{y}}{F S}
$$

Escolhendo um eletrodo E70XX, $\sigma_{y}=70 k p s i$, ou $482,63 \mathrm{MPa}$, deve-se ter $\frac{a}{F S} \geq$ 
0,936. Com $a=2 \mathrm{~mm}$, o fator de segurança é $F S=2,137$. A especificação da solda, portanto, é $a 2 V E 308 L-17$.

Vale lembrar que, nesse cálculo, foi desconsiderada a flange da seção transversal, o que significa que o fator de segurança está subdimensionado.

À direita da célula de carga, outra estrutura em aço 304 (figuras 4.16 e 4.17) foi usada para transferir a força da mesa linear para a célula de carga. Como a distância da linha de atuação da força à solda é menor que na estrutura em $U$, o que reduz drasticamente o momento e, consequentemente, a tensão gerada por ele, foi adotada a mesma solda para esta estrutura.

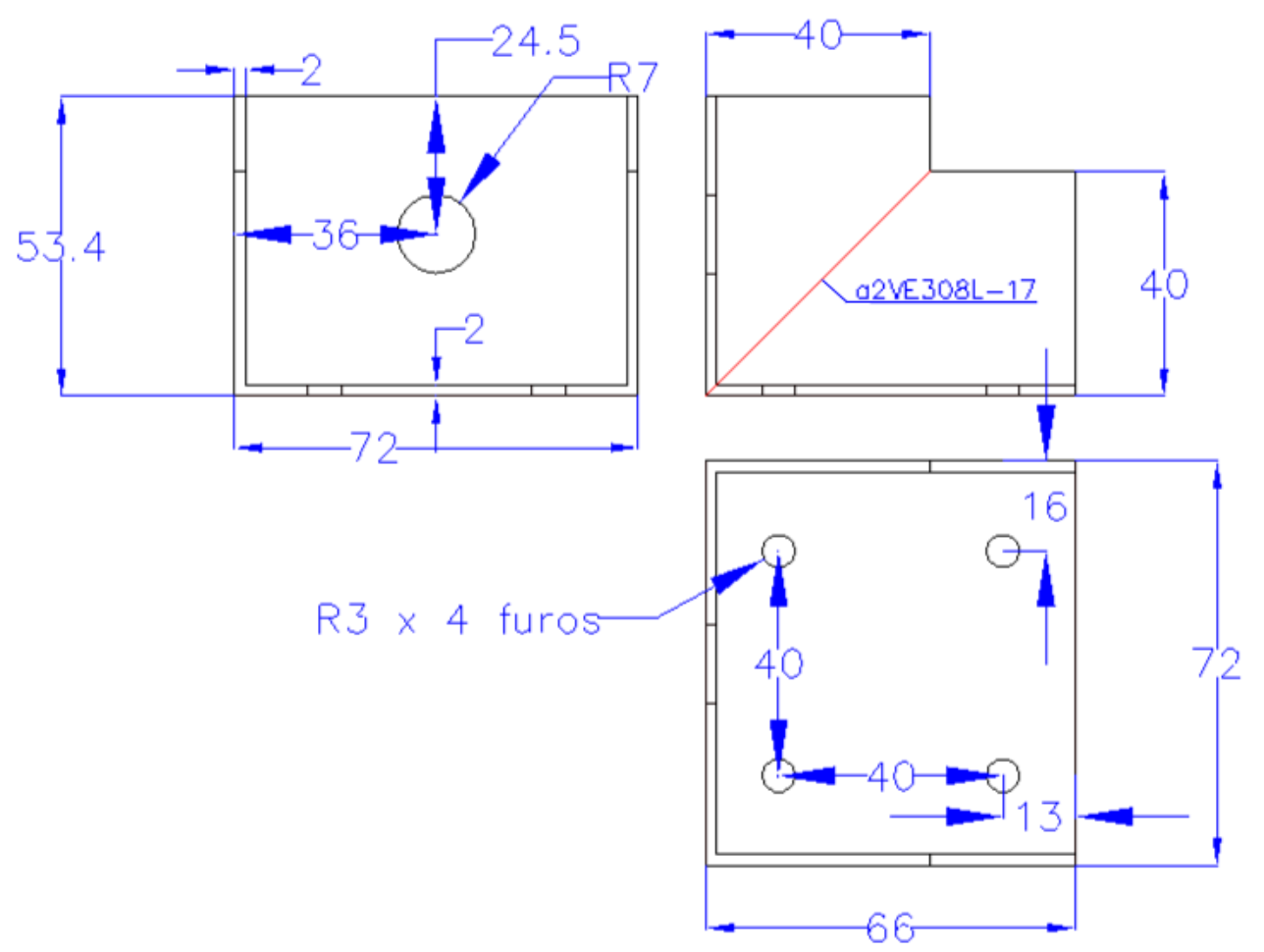

Figura 4.16: Estrutura entre a mesa linear e a célula de carga. Transmite a força do carrinho da mesa linear para a célula de carga.

A figura 4.17, em aço 304, mostra a estrutura construída para a união da estrutura em U à célula de carga. 


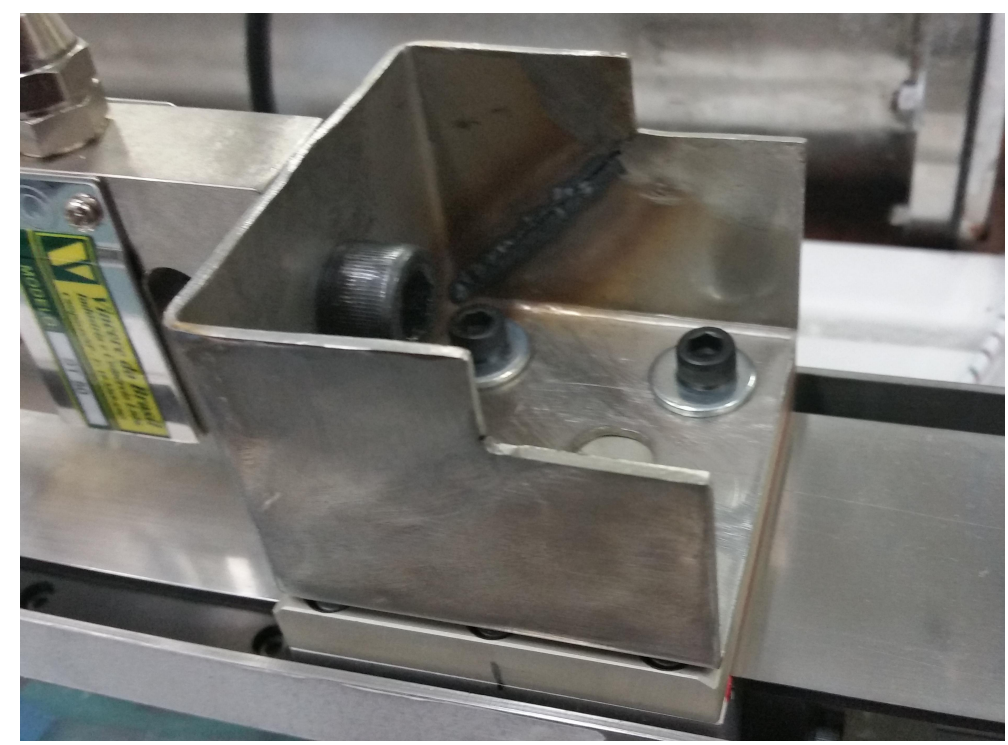

Figura 4.17: Foto da estrutura entre a mesa linear e a célula de carga.

Testes preliminares de insuflamento revelaram que a pressão interna atuante no espécime causava flambagem da estrutura em $U$, à medida em que a atuação dessa pressão sobre a superfície, da garra, paralela ao plano $y-z$ induzia, sobre a garra e, consequentemente, sobre a estrutura em $\mathrm{U}$, uma força na direção $x$, para a direita. Para aumentar a resistência à flambagem foi, portanto, soldada uma chapa de aço de mesma espessura, $2 \mathrm{~mm}$, no interior da estrutura em $U$, fechando o seu perfil. Isso é visível na figura 4.18 .

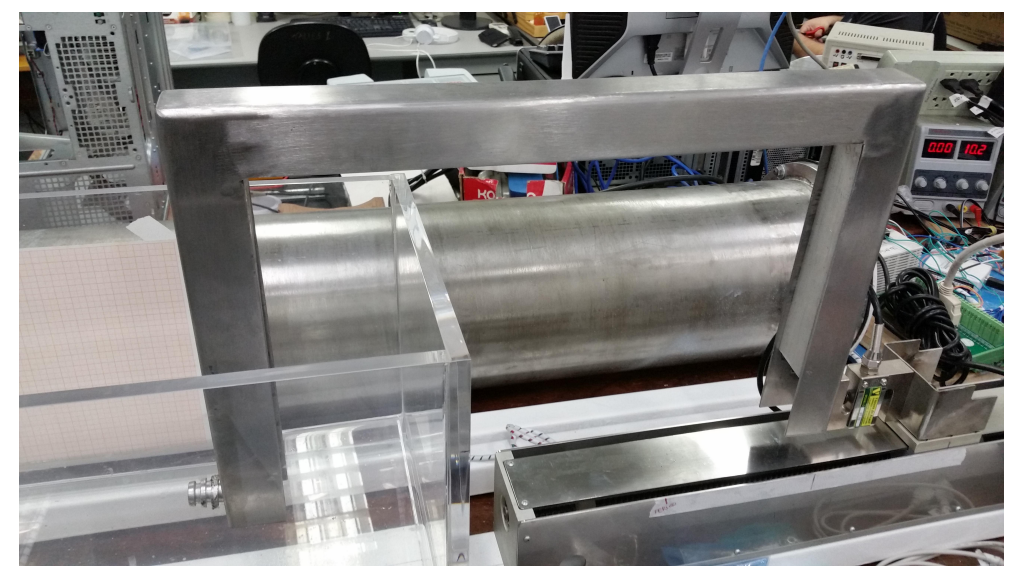

Figura 4.18: Foto da estrutura em U, evidenciando o fechamento do perfil, no intuito de aumentar sua resistência à flambagem.

Sob tração de $500 \mathrm{~N}$, cada uma das hastes verticais da estrutura em U deformará 0,132 mm na direção $x$ ou, ambas somadas, $5,28 \cdot 10^{-4} \mathrm{~mm} / \mathrm{N}$. Essa deformação é linear 
com a força aplicada, conforme a equação (4.8),

$$
w(L)=-\frac{P L^{3}}{3 E I_{x}}
$$

onde $w$ denota a deformação, $L$ denota a distância ao ponto de aplicação da força, $P$ denota a carga aplicada, $E$ denota o módulo de Young e $I_{x}$ denota o momento de área.

A parte superior da estrutura, por sua vez, deformará conforme a equação (3.8). Pode-se calcular a deformação máxima,

$$
\begin{aligned}
\epsilon_{\max } & =\frac{\sigma_{\max }}{E} \\
\epsilon_{\max } & =\frac{F_{\max }}{A E},
\end{aligned}
$$

onde a área é constante, $A=304 \mathrm{~mm}^{2}, F_{\max }=500 \mathrm{~N}$ e $E=210 \mathrm{GPa}$.

Nota-se que essa deformação é linear com a força, e seu valor máximo é 0, 0000078 do comprimento inicial, o que resulta em $\approx 0,00366 \mathrm{~mm}$, ou $7,32.10^{-6} \mathrm{~mm} / \mathrm{N}$.

A deformação da estrutura em $U$ resulta da soma dos dois efeitos, resultando em $\epsilon_{U}=5,35.10^{-4} \mathrm{~mm} / \mathrm{N}$, ou $0,27 \mathrm{~mm}$ para a força máxima esperada. De posse desse resultado, a deformação de espécimes submetidos à tração será determinada descontando-se a da estrutura, $\epsilon_{U}$.

\subsubsection{Cuba}

No intuito de permitir a filmagem do teste e o armazenamento da solução fisiológica para o banho dos espécimes em seu interior, a cuba de ensaios foi construída em acrílico e, para que suportasse com folga a coluna d'água em seu interior, sua espessura foi estabelecida em $10 \mathrm{~mm}$, conforme mostram as figuras $4.19 \mathrm{e} 4.20$. 

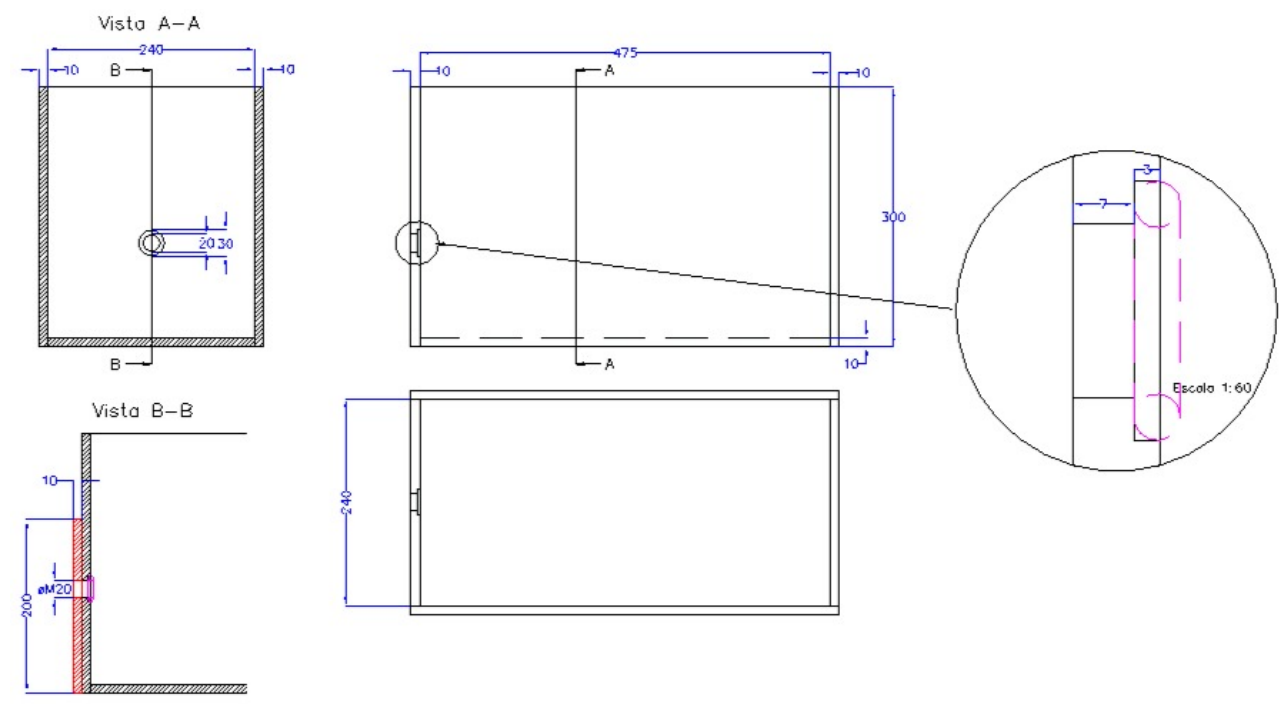

Figura 4.19: Projeto da cuba de ensaios, construída em acrílico de espessura $10 \mathrm{~mm}$, a fim de permitir a filmagem dos testes, durante os quais os espécimes ficam permanentemente imersos em solução fisiológica.

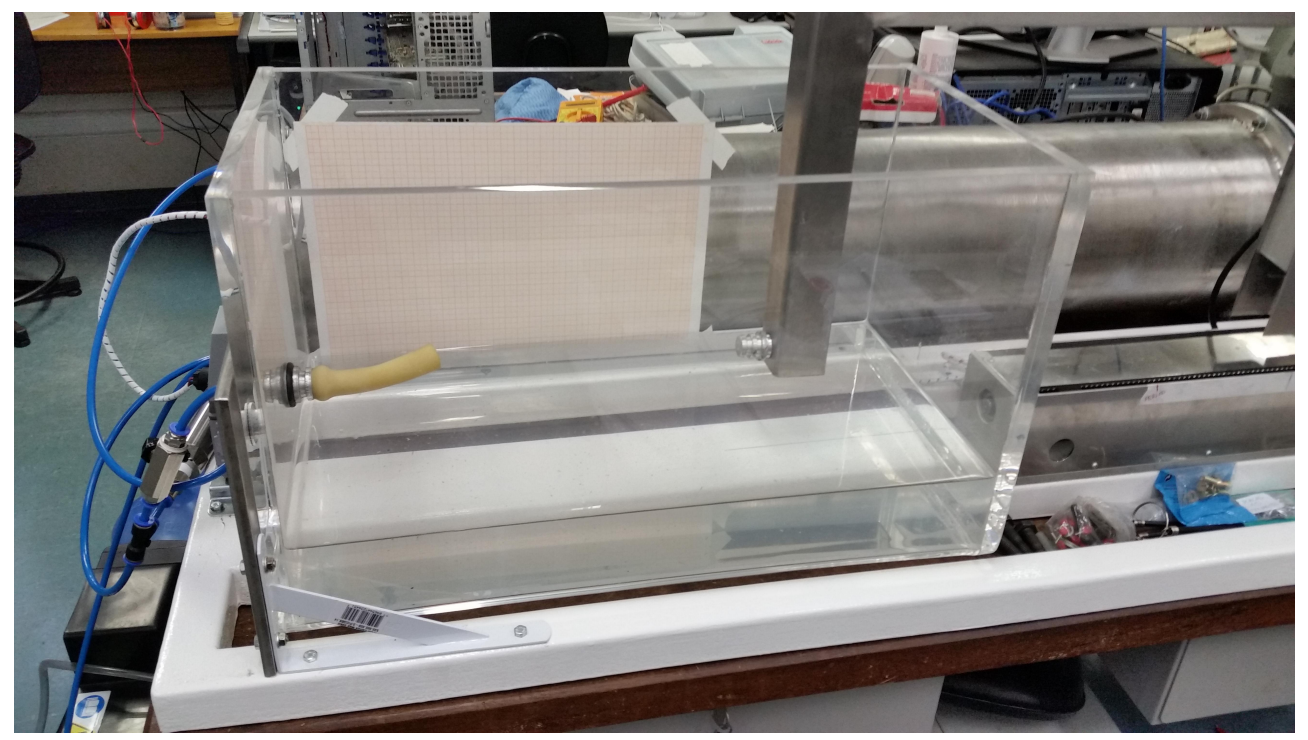

Figura 4.20: Foto da cuba de ensaios, parcialmente preenchida com água.

As tabelas 4.1 (página 49) e 4.2 (página 50) foram utilizadas da determinação das dimensões internas da cuba, de modo a manter completamente imerso qualquer espécime durante todo o ensaio, sem que tocasse as paredes. Assim, para que o maior diâmetro (170, $99 \mathrm{~mm}$ ) fosse garantido, o nível de líquido na cuba (eixo y) foi definido em $240 \mathrm{~mm}$, dimensão adotada também no eixo $z$. Internamente, a altura total da cuba foi estipulada em $300 \mathrm{~mm}$, sendo, o propósito da diferença, evitar derramamentos 
durante os ensaios. No eixo $x$, a cuba de ensaios tem, internamente, $475 \mathrm{~mm}$.

Uma chapa de aço (figura 4.21), foi fixada à esquerda da cuba, por meio de mãos francesas parafusadas à base, com a finalidade de resistir ao esforço exercido pela garra durante os ensaios. A garra foi fixada à chapa de aço por meio de um furo passante rosqueado, conforme apresentado na seção 4.3.1. A figura 4.19 evidencia o detalhe de dois furos concêntricos de diâmetros distintos. O maior deles acomodou um o-ring, para a vedação do líquido contido na cuba, de 5, $40 \mathrm{~mm}$ de espessura e 20,25 mm de diâmetro interno, sendo que, através do furo menor, passou a garra. Uma porca M20 fixou a garra pelo lado esquerdo da chapa de aço.

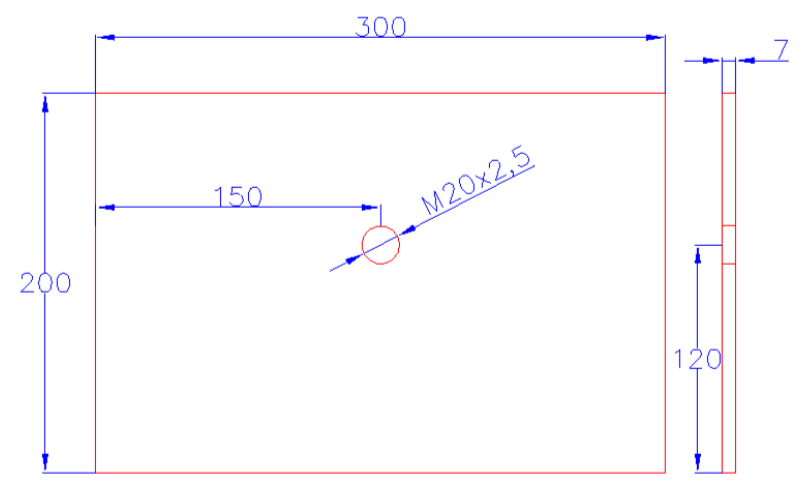

Figura 4.21: Chapa de aço, introduzida para fins de fixação da garra da esquerda, através de um furo passante rosqueado. É fixada à base através de mãos francesas, e localizada à esquerda da cuba de ensaios.

Uma vez que o aço é um material dúctil, foram analisadas, através dos softwares Gmesh, Calculix e Octave, as tensões de Von Mises e as deformações nessa estrutura, quando submetida à força máxima prevista. Os resultados podem ser apreciados na figura 4.22 , obtido através do método dos elementos finitos $(M E F)$, com a força igualmente distribuída nos nós componentes de cada furo. 


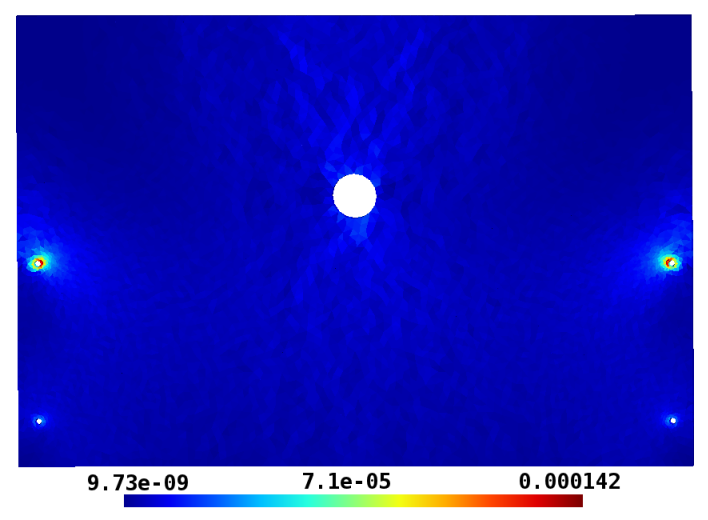

(a) Tensões de Von Mises

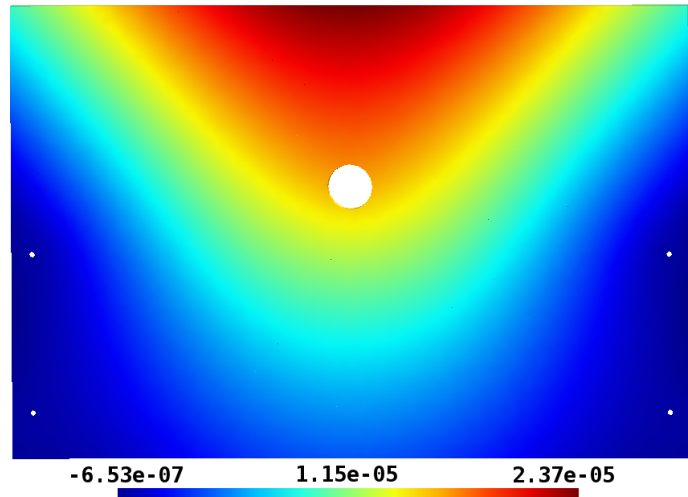

(b) Deformações

Figura 4.22: Tensões e deformações na chapa. Resultado obtido pelo MEF, com o uso dos softwares Gmesh, Calculix e Octave. Nota-se que a deformação máxima não é capaz de danificar a parede da cuba, e que a tensão máxima fica muito abaixo do limite de escoamento do material.

Com todas as unidades no sistema internacional, ficou evidente que as tensões estariam muito abaixo do limite de escoamento do material, e que as deformações seriam incapazes de danificar a parede da cuba.

\subsubsection{Mecanismo de tração longitudinal}

Dadas a grande variedade de tecidos que o equipamento a ser desenvolvido poderia testar, a possibilidade de que alguns partissem de comprimentos maiores que $100 \mathrm{~mm}$ e a necessidade de imersão em solução salina durante todo o tempo, foi descartado o teste na vertical, como a primeira máquina descrita na seção 2.4.1. Essa decisão foi tomada porque, ao se testarem, nessa direção, espécimes de comprimento maior, a coluna de líquido em seu interior promoveria gradientes de deformação não nulos no eixo $y$, o que seria indesejável. Além disso, era parte da proposta do presente equipamento, ensaiar os tecidos até a ruptura, o que aumentaria o curso livre necessário. Assim, optou-se por se realizarem todos os testes na horizontal, decisão que implicaria, para espécimes de diâmetro maior, em uma maior diferença de coluna d'água sobre pontos de diferentes coordenadas $y$. Na parte inferior dos espécimes, a pressão externa tenderia a contrabalancear melhor a pressão em seu interior.

As necessidades de se manterem os espécimes imersos em solução salina durante todo o ensaio e de se garantir a estanqueidade do tanque foram solucionadas pela 
introdução de um quadro em U que transmitisse a força sem gerar momento na célula de carga, visto que a presença de um momento dificultaria a conversão, para newton, do valor de tensão elétrica lido, em volt. Para que isso fosse possível, o eixo central da célula de carga foi alinhado à linha da força de tração no espécime.

Além disso, como seria necessário haver troca de fluidos entre o reservatório e o espécime, decidiu-se que a garra contendo o furo passante seria a da esquerda, uma vez que, se fosse a da direita, eventuais vibrações poderiam causar interferência na leitura da célula de carga.

Dessa forma, o mecanismo de tração longitudinal foi composto por garras, estrutura em $\mathrm{U}$, célula de carga (figura 4.23), mesa linear de curso livre $350 \mathrm{~mm}$ (figura 4.24), redutor planetário de $32: 1$ (figura 4.25(a)), servomotor, marca Delta, modelo ECMA-C20604ES (figura 4.25(b)), e servodrive (figura 4.26), marca Delta, modelo ASD-A2-0421-M, com alimentação $220 \mathrm{~V}$, potência $400 \mathrm{~W}$ e torque máximo $1,27 \mathrm{Nm}$.

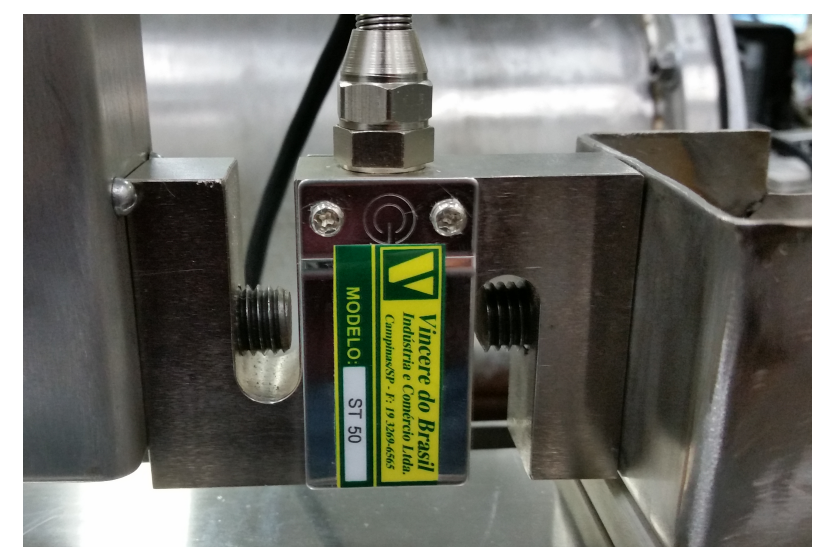

Figura 4.23: Foto da célula de carga de capacidade $500 \mathrm{~N}$, alimentada com $10 \mathrm{~V}, V_{C C}$.

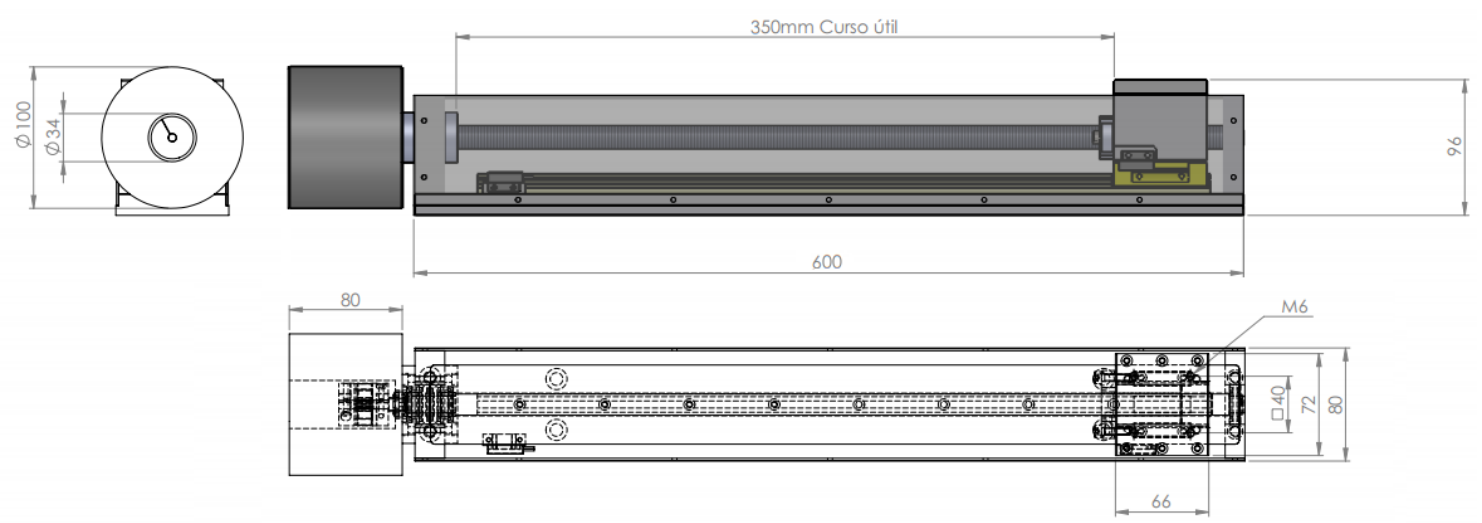

Figura 4.24: Mesa linear, de curso livre $350 \mathrm{~mm}$. Fonte: Kalatec Automação 


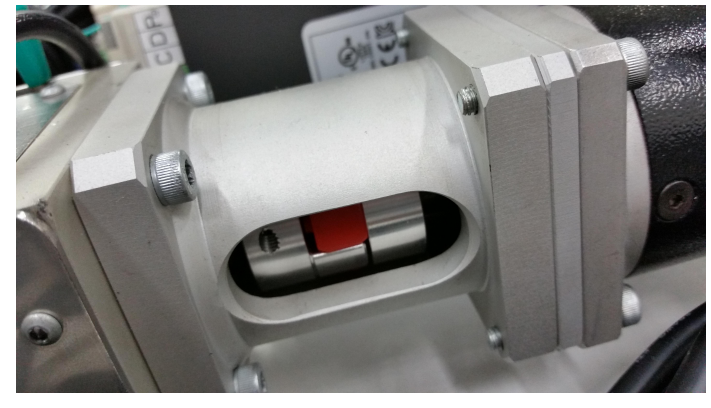

(a) Redutor

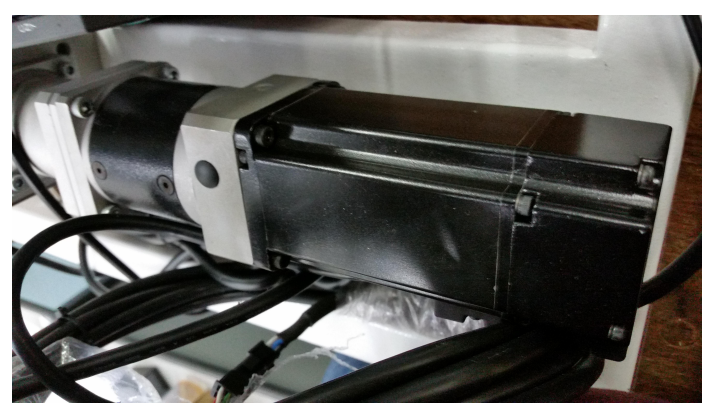

(b) Servomotor

Figura 4.25: Fotos do redutor planetário de $32: 1$ e do servomotor, marca Delta, modelo ECMA-C20604ES.

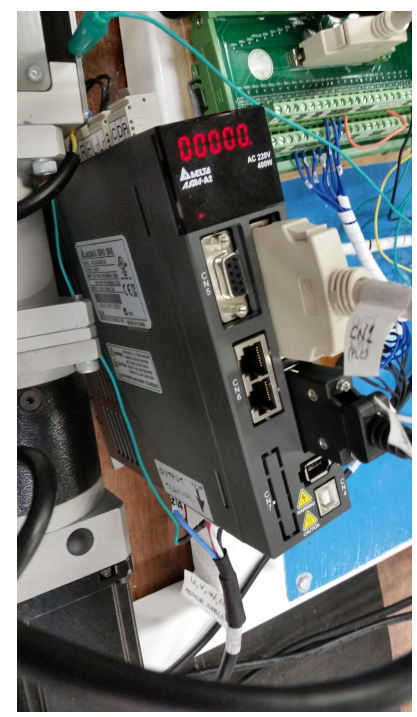

Figura 4.26: Foto do servodrive, marca Delta, modelo ASD-A2-0421- $M$, com alimentação $220 \mathrm{~V}$, potência $400 \mathrm{~W}$ e torque máximo 1,27 Nm.

Conforme sugere a figura 4.27 e conforme mostra a figura 4.28 , a garra da esquerda foi fixada à chapa localizada à esquerda da cuba de ensaios, conforme descrito na seção 4.3.1. A garra da direita, por sua vez, foi rosqueada à estrutura em $U$, esta parafusada à célula de carga, de capacidade nominal $500 \mathrm{~N}$ e medidas 76, $2 \mathrm{~mm}, 50,8 \mathrm{~mm}$ e 12, $0 \mathrm{~mm}$, com um parafuso Allen M6. A outra extremidade da célula de carga foi fixada, por meio do mesmo tipo de parafuso, à pequena estrutura que a conecta à mesa linear, cujo movimento obedece à rotação do servomotor, reduzido em trinta e duas vezes. Quando o servodrive manda sinal para o servomotor, tração longitudinal é imposta ao espécime. 


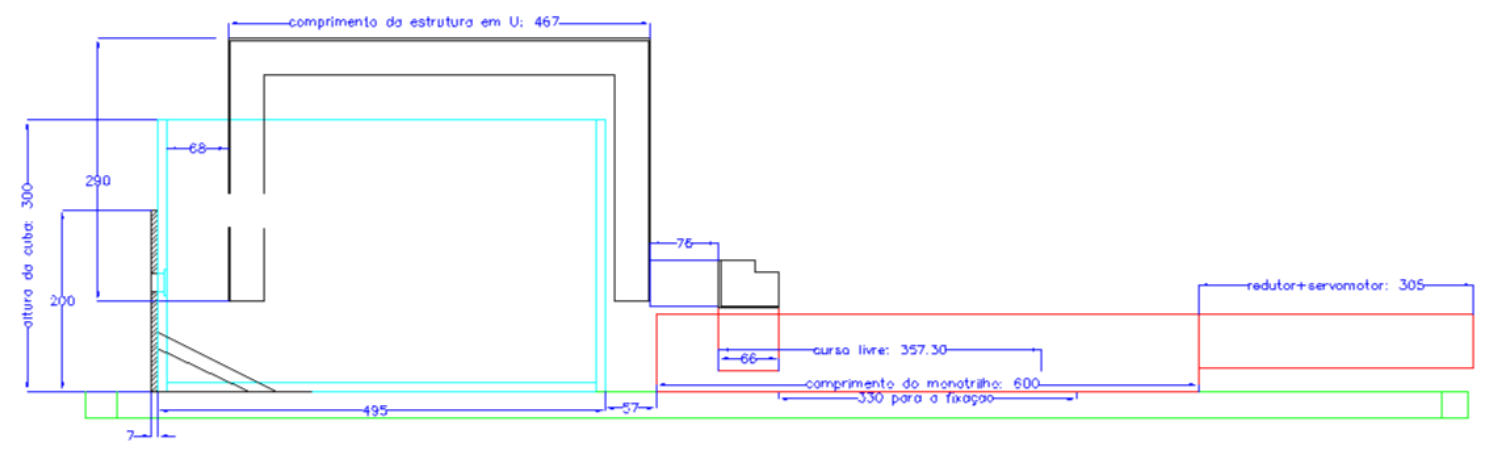

Figura 4.27: Vista de conjunto das partes relevantes ao ensaio de tração

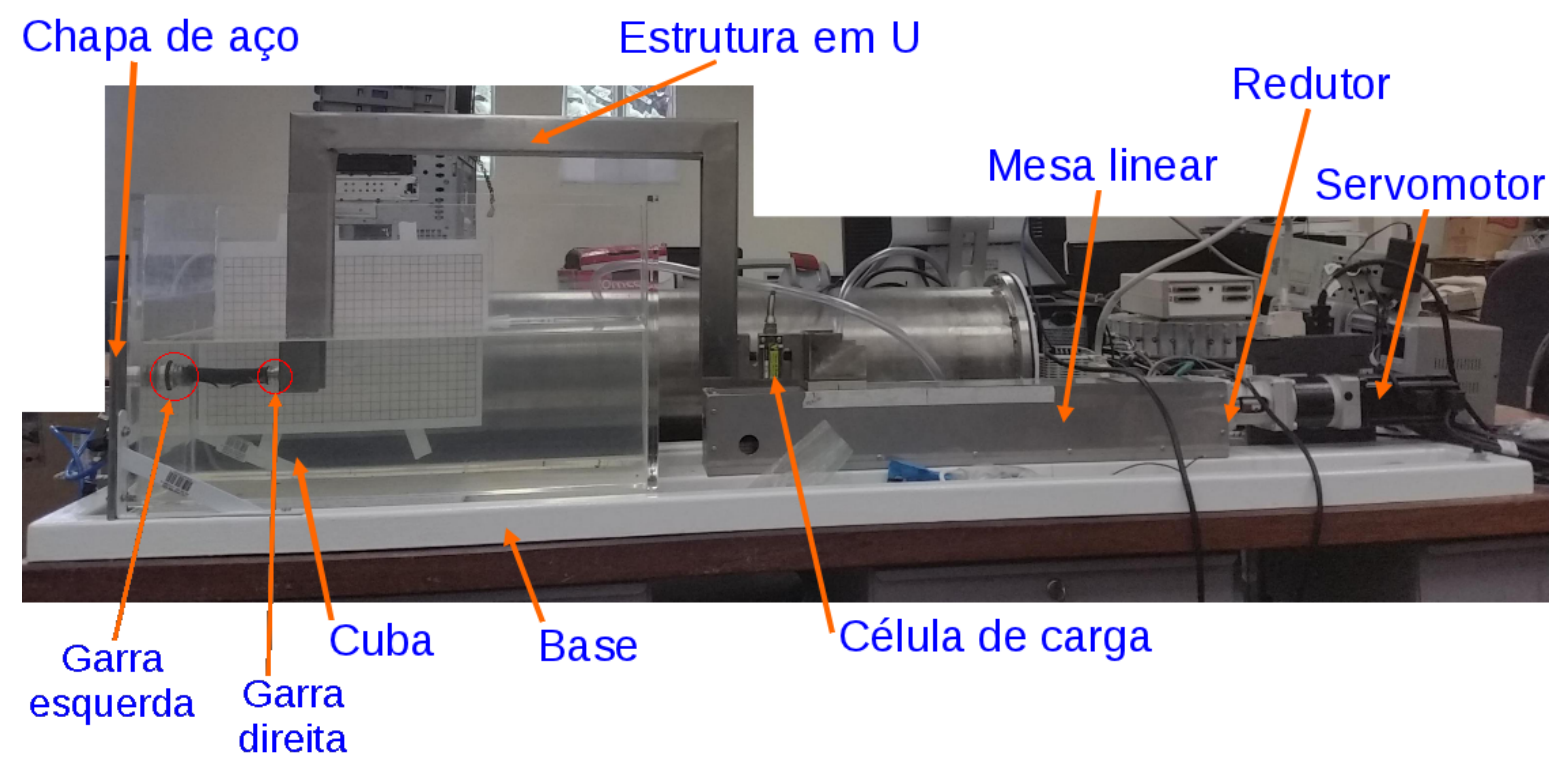

Figura 4.28: Vista frontal do equipamento, ilustrando a montagem para a realização do ensaio de tração

A saída da célula de carga é proporcional à sua alimentação, $3 \mathrm{mV}$ por volt, para a carga máxima. No intuito de melhorar a resolução de leitura, foi montado um circuito (figura 4.29) para a amplificação do sinal, com o amplificador de instrumentação INA126, cujo ganho depende da resistência usada. Foi usado o potenciômetro 3005P 501 , cuja resistência varia de 0 a $500 \Omega$, para viabilizar a variação do ganho conforme a necessidade. Foram utilizadas duas fontes, dispostas de modo a fornecer alimentação simétrica ao amplificador operacional. A figura 4.29 também ilustra o circuito para a aquisição de sinal diferencial dos dados amplificados pelo computador, através de uma placa de aquisição. 


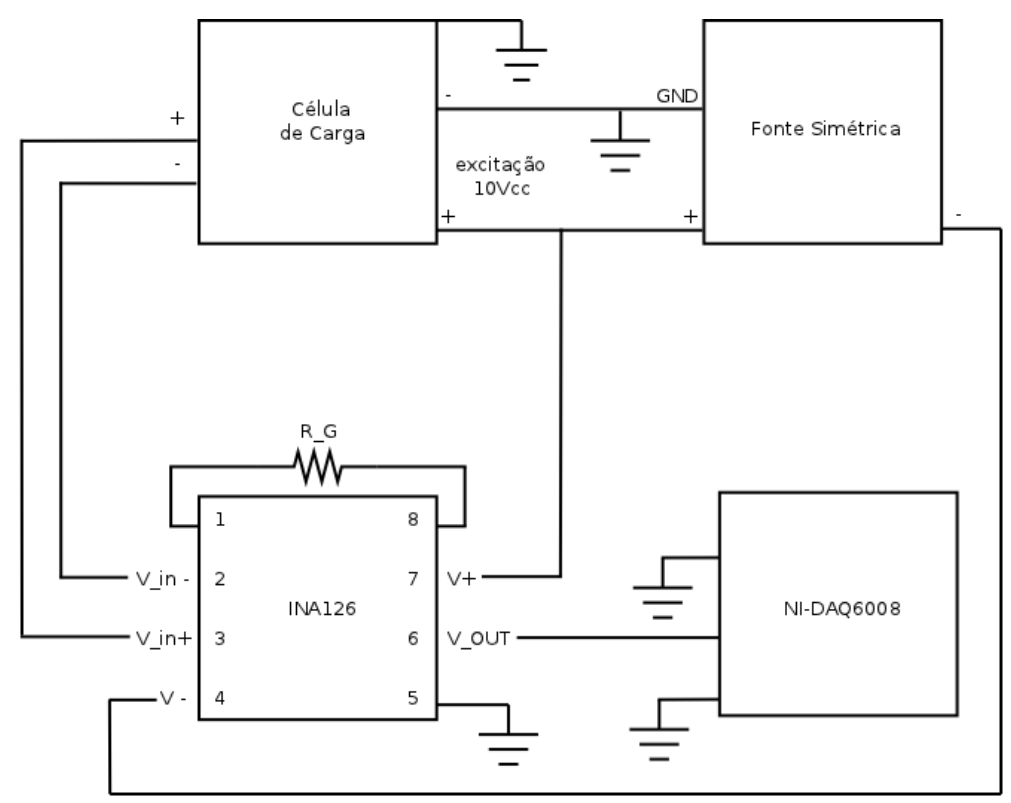

Figura 4.29: Esquema elétrico para a alimentação da célula de carga e do circuito de amplificação (INA126) do sinal lido. Para a confecção deste desenho, foi usado o Software livre DIA.

Ao se testarem espécimes com baixa resistência à tração, ou seja, aqueles que rompem sob a aplicação de forças de baixa magnitude, recomenda-se que a resistência do potenciômetro seja diminuída manualmente, o que implicará no aumento do ganho no amplificador. Os resultados apresentados no capítulo 4.9(a) foram obtidos com o potenciômetro configurado em $410 \Omega$, resultando em amplificação de duzentas vezes. A alimentação da célula de carga, $10 \mathrm{~V}, V_{C C}$, foi feita pelas mesmas fontes usadas na alimentação do amplificador de instrumentação, conforme a figura 4.29 .

\subsubsection{Mecanismo de insuflamento}

Para que se pudessem atingir as pressões calculadas e apresentadas na tabela 4.2 (página 50), foi usado um compressor, na saída do qual foi introduzida uma válvula proporcional, responsável pelo controle de uma pressão de referência, a pressão do ar no interior do tanque, posicionado na saída da válvula. O espécime, por sua vez, encontrar-se-ia na saída do tanque, uma parte do qual seria preenchida por solução fisiológica. Nessa configuração, seria possível calcular a pressão interna ao espécime, a partir da pressão de referência (figura 4.30). Esse cálculo será abordado em maiores detalhes na presente seção. A figura 4.31(a) é uma foto desse mecanismo, e os fluxos 
de solução fisiológica e de ar entre o compressor e o espécime podem ser melhor compreendidos na figura $4.31(\mathrm{~b})$.

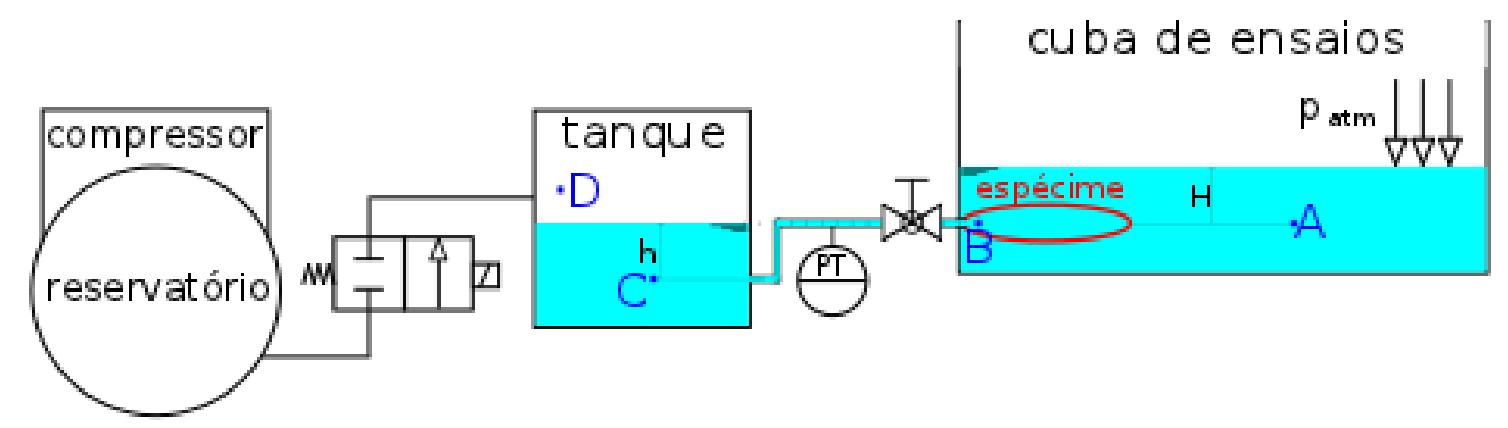

Figura 4.30: Mecanismo idealizado para o insuflamento do espécime. Ar comprimido é armazenado no reservatório, e uma válvula proporcional controla a pressão em sua saída, acoplada a um tanque, uma parte do qual é preenchida por água. O tanque, por sua vez, é ligado ao espécime, através da garra da esquerda. Antes de chegar ao espécime, contudo, o líquido em seu interior passa por um transdutor de pressão (PT), que coleta os dados e os envia à placa de aquisição. Uma válvula esfera protege o espécime durante a sua fixação às garras.

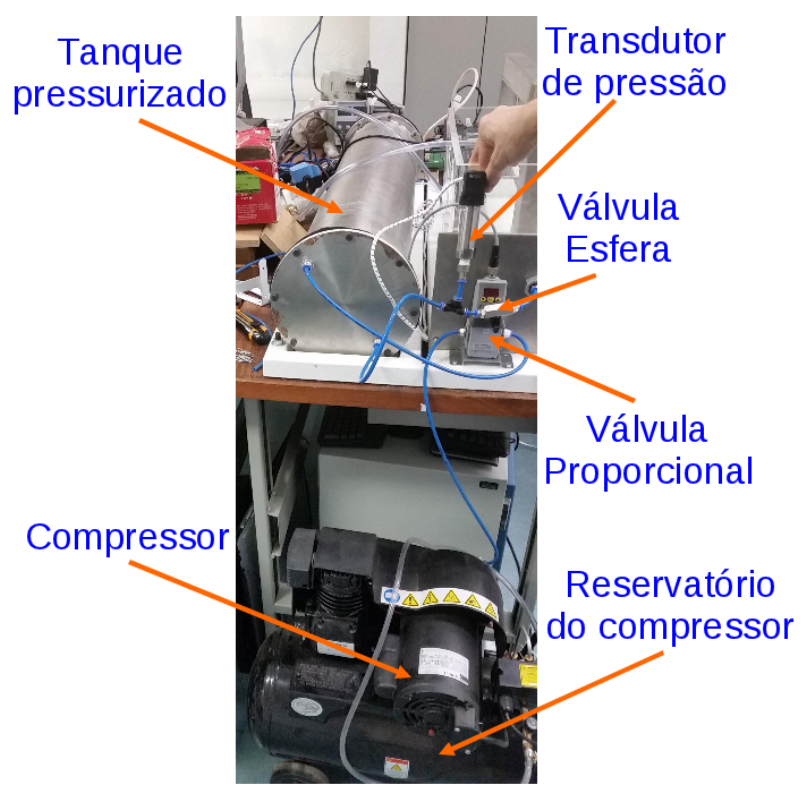

(a) Vista do equipamento, evidenciando o mecanismo descrito e ilustrando a montagem para a realização do ensaio de insuflamento

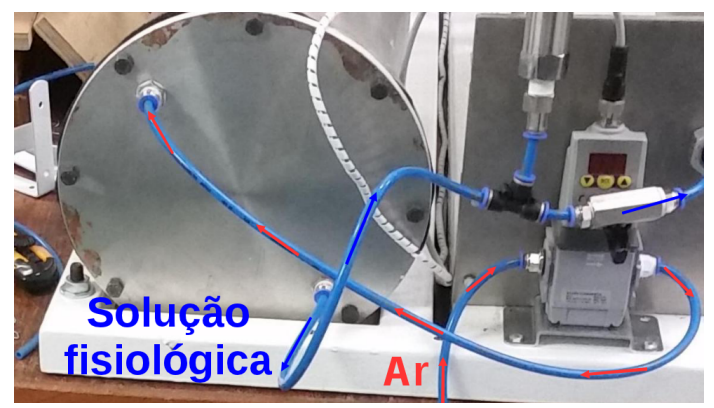

(b) Ilutração dos fluxos de ar e de solução fisiológica para a viabilização do ensaio de insuflamento

Figura 4.31: Mecanismo de insuflamento

No intuito de facilitar o cálculo dessa pressão, era desejável que o nível do líquido 
no interior do tanque se mantivesse aproximadamente constante, mesmo diante da alteração desse volume, em seu interior, em até $1700 \mathrm{~mL}$. Assim, foi adotado, para o tanque, um comprimento elevado. Se fosse maior, seu custo, volume e massa seriam altos demais, encarecendo o projeto e dificultando o manuseio por parte dos operadores. O diâmetro do tanque não poderia ser muito maior, para minimizar a força gerada sobre o tampo do vaso de pressão, o que dificultaria a vedação do tanque, elevando, inclusive, o número de parafusos necessários para isso, o que, por sua vez, dificultaria sua abertura e fechamento, necessários a cada vez que se quisesse alterar o volume de líquido em seu interior.

Para todas as conexões, foram usados tubos de poliuretano de diâmetro externo $6 \mathrm{~mm}$ e diâmetro interno $3 \mathrm{~mm}$, capazes de suportar pressões internas de até $1000 \mathrm{kPa}$.

Dessa forma, o mecanismo para o insuflamento dos espécimes parte do compressor de ar, marca Schulz, modelo Pratic Air CSI 7,4/30 (figura 4.32(a)), com vazão máxima de $7,4 \mathrm{~m}^{3} /$ min e pressão máxima de 9,67 bar, que armazena ar comprimido em um reservatório com capacidade para $30 \mathrm{~L}$. Na saída do reservatório, foi posicionada a válvula carretel proporcional reguladora de pressão relativa da marca Parker, modelo P31PA12AD2VD1A (figura 4.32(b)), com a função de controlar a pressão no interior do tanque cujo projeto é mostrado na figura 4.33 .

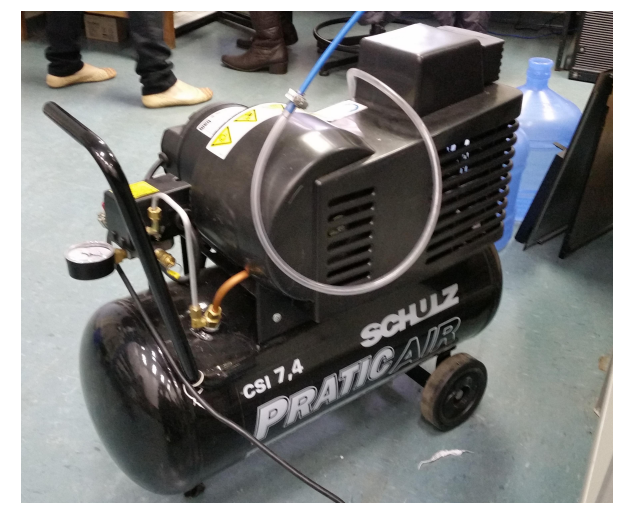

(a) Compressor de ar

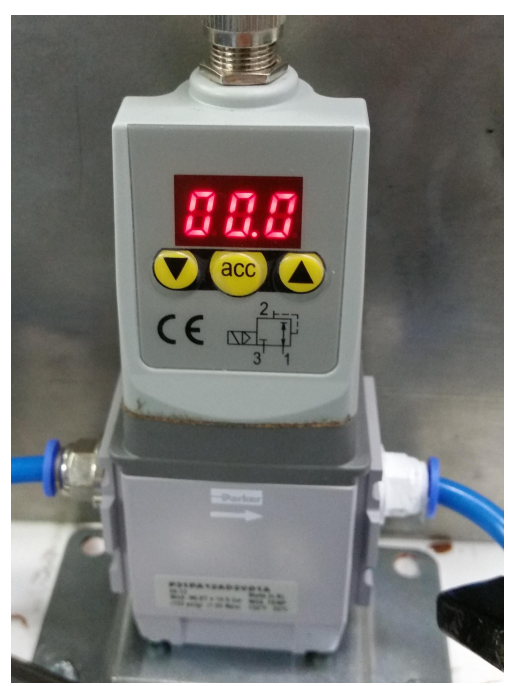

(b) Válvula proporcional

Figura 4.32: Fotos do compressor de ar, marca Schulz, modelo Pratic Air CSI 7,4/30, e da válvula proporcional reguladora de pressão relativa, marca Parker, modelo P31PA12AD2VD1A 
Para suportar pressões de até $500 \mathrm{kPa}$, a equação (2.2) permitiu o projeto, construção e teste de um vaso de pressão. Construído em aço 304, calandrado e soldado, suas medidas foram determinadas de modo iterativo, $1000 \mathrm{~mm}$ de comprimento, $3 \mathrm{~mm}$ de espessura e $200 \mathrm{~mm}$ de diâmetro interno. Às áreas de contato com a solução fisiológica, foi aplicada pintura em poliuretano $(P U)$, evitando, assim, corrosão por pite, promovida pela presença de íons $C l^{-}$.

Com essas medidas, a equação (2.2) retorna uma tensão máxima, na parede do vaso de pressão, de 16,92 MPa. Sendo o limite de escoamento do aço 304, à temperatura ambiente, por volta de $280 \mathrm{MPa}$ [49], e considerando que, na região de solda, essa tensão seja reduzida a $70 \%$ desse valor [48], o fator de segurança calculado foi de $\frac{0,7.280}{16,92}=11,58$.

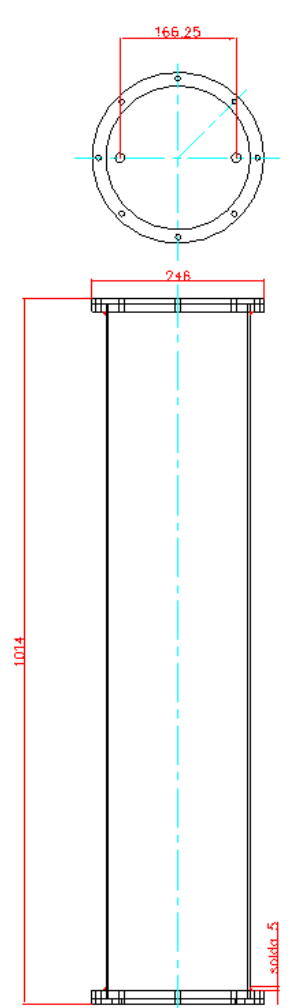

(a) Conjunto

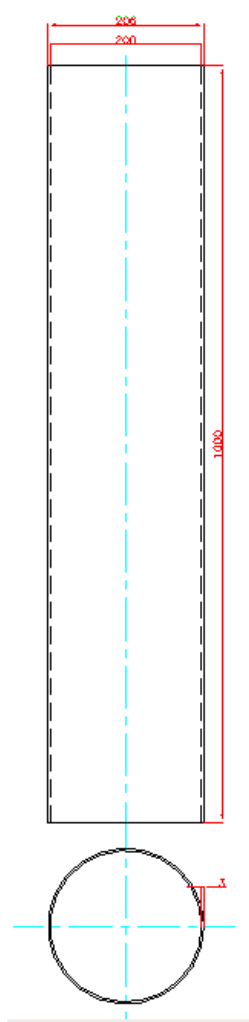

(b) Cilindro
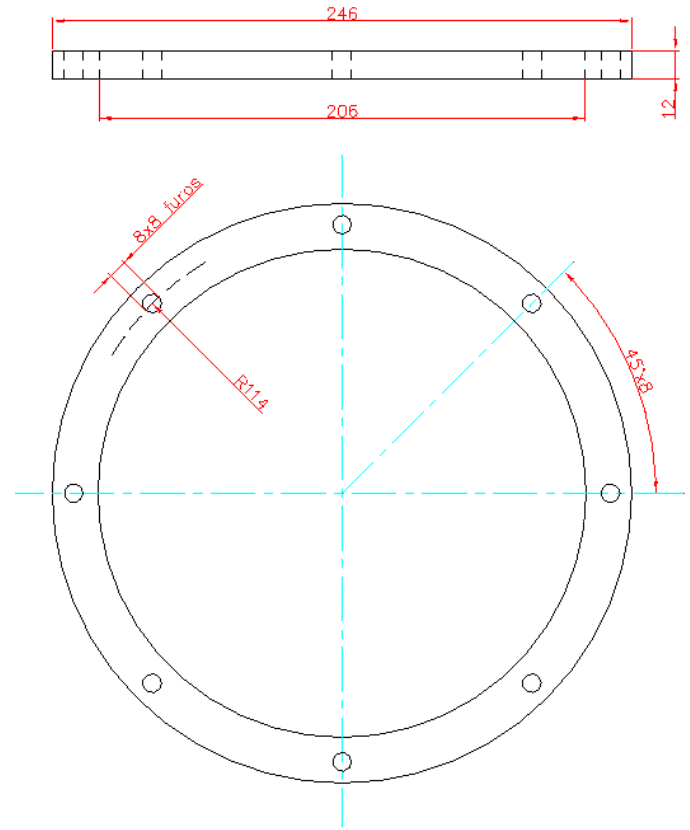

(c) Flange

Figura 4.33: Tanque para o armazenamento de solução fisiológica sob pressão controlada

A figura 4.34 mostra os tampos desse vaso de pressão, ambos com a furação necessária para a vedação, e um deles com dois furos extras, o primeiro para a troca de ar com o compressor, e o segundo para a troca de solução fisiológica com a cuba de 
ensaios. Quando ocorre a ruptura do espécime, a pressão do tanque tende a expulsar rapidamente o líquido em seu interior para a cuba. Por isso, no intuito de se evitarem derramamentos e para garantir a integridade não somente dos espécimes durante a sua fixação, mas também das outras partes do equipamento após a ruptura do espécime, uma válvula esfera foi instalada entre os dois.

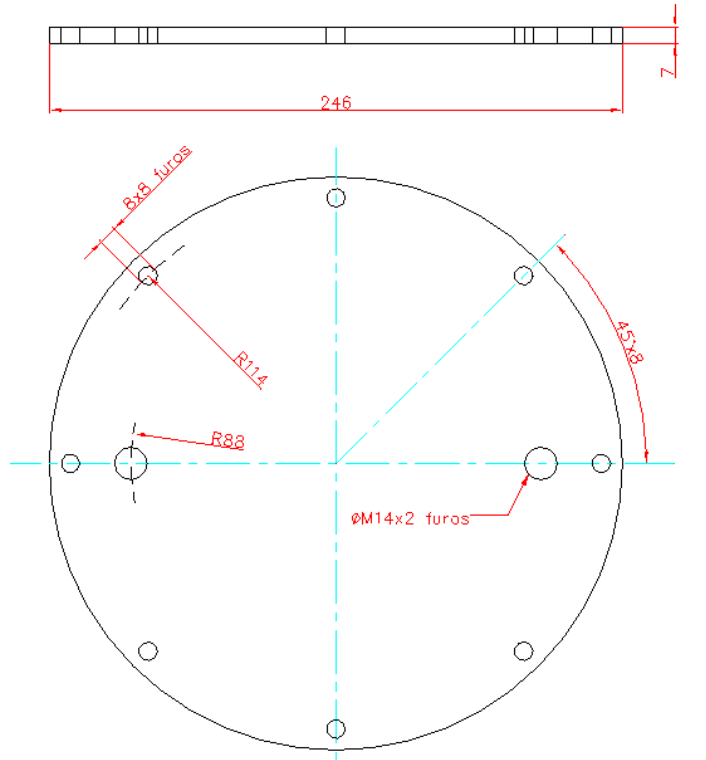

(a) Tampo com a furação necessária à vedação do tanque e 2 furos a mais, sendo um deles para a troca de ar com a válvula proporcional e, o outro, para a troca de solução fisiológica com o espécime.
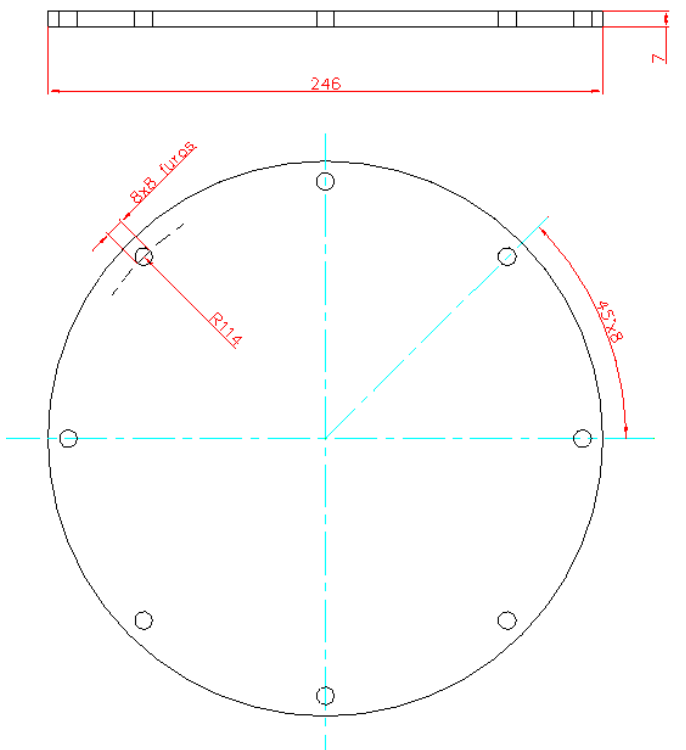

(b) Tampo sem furos extra.

Figura 4.34: Tampos do vaso de pressão criado

Uma vez que a válvula proporcional não permitiria a aquisição da pressão de referência, foi posicionado, entre o tanque e a válvula esfera (ponto B da figura 4.30), um transdutor de pressão piezorresistivo da marca Zurich, modelo MTP-420 - 5bar 0-10Vcc - DIN - $14 \mathrm{~N}$, com fundo de escala de 0 a 5 bar, saída de 0 a $10 \mathrm{~V}$, precisão de $0,25 \%$ do fundo de escala na leitura, alimentado com $24 \mathrm{~V}, \mathrm{Vcc}$ (figura 4.35). 


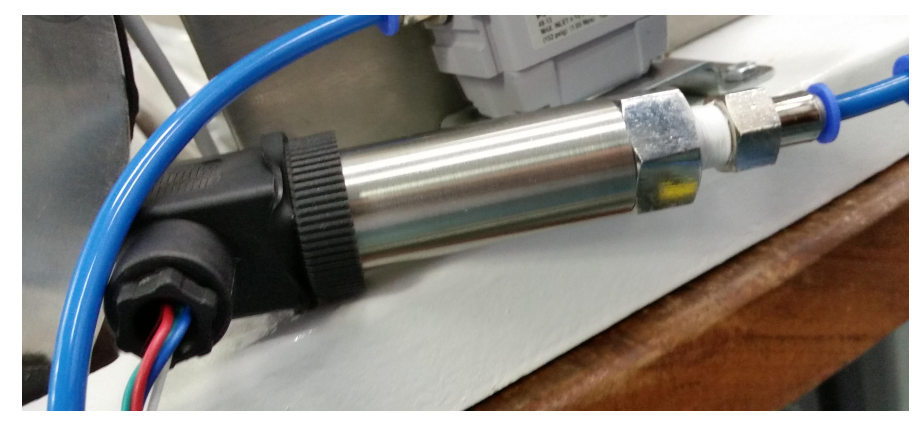

Figura 4.35: Foto do transdutor de pressão

O nível da solução fisiológica no tanque cilíndrico deveria ser conhecido. Dessa forma, far-se-iam possíveis os seguintes cálculos.

Na figura 4.30, a pressão no ponto A é,

$$
\begin{aligned}
& p_{r e l, A}=\rho . g . H \\
& p_{a b s, A}=p_{a t m}+\rho . g . H,
\end{aligned}
$$

onde $p_{r e l}$ denota a pressão em relação à atmosfera, $p_{a b s}$ denota a pressão absoluta, $g$ denota a aceleração da gravidade, e $p_{a t m}$ denota a pressão atmosférica.

Para que houvesse insuflamento, seria necessário que a pressão no interior do espécime fosse maior que no meio ao seu redor, ou seja, $p_{a b s, B}>p_{a b s, A}$. A diferença entre as pressões em B e em A seria a pressão necessária para vencer a força elástica resistiva da parede do espécime. Essa pressão foi chamada de $p_{e l}$. Assim,

$$
\begin{aligned}
& p_{a b s, B}=p_{a b s, A}+p_{e l} \\
& p_{a b s, B}=\rho \cdot g \cdot H+p_{a t m}+p_{e l} \\
& p_{r e l, B}=\rho \cdot g \cdot H+p_{e l} .
\end{aligned}
$$

Como o tanque e a cuba de ensaios se comunicam,

$$
p_{r e l, C}=p_{r e l, B}+\rho . g . h+R . F,
$$

onde $R$ denota resistência, e $F$ denota fluxo de masssa. 
Como o teste em questão era quase estático, aproximou-se $F$ a zero. Assim,

$$
\begin{aligned}
& p_{r e l, C}=p_{r e l, B}+\rho \cdot g \cdot h \\
& p_{r e l, C}=\rho \cdot g \cdot h+\rho \cdot g \cdot H+p_{e l} \\
& p_{a b s, C}=\rho \cdot g \cdot h+\rho \cdot g \cdot H+p_{a t m}+p_{e l} .
\end{aligned}
$$

Finalmente, no ponto D,

$$
\begin{aligned}
& p_{r e l, D}=p_{r e l, C}-\rho \cdot g \cdot h \\
& p_{r e l, D}=\rho \cdot g \cdot H+p_{e l} \\
& p_{a b s, D}=\rho \cdot g \cdot H+p_{e l}+p_{a t m}
\end{aligned}
$$

Nessa configuração, $p_{r e l, B}=p_{r e l, D}$. Assim, o transdutor, posicionado no ponto B, lê a pressão no espécime, $p_{r e l, B}$, que coincide com a do ar no interior do tanque (ponto $D$ ), possibilitando, assim, a verificação a precisão da válvula proporcional. Para se obter $p_{e l}$, basta subtrair $\rho . g . H$ da pressão correspondente à leitura realizada pelo transdutor, conforme a equação (4.9),

$$
p_{e l}=p_{\text {rel,B }}-\rho . g . H .
$$

\subsubsection{Base}

A base foi projetada e construída de modo a garantir que não houvesse deslocamentos relativos entre os subsistemas. Visando à redução do custo e da massa do sistema, foram soldados alguns perfis em $U$, de duas seções transversais distintas, conforme mostra a figura 4.36. Um deles (figura 4.37(a)), correspondente à vista $\mathrm{C}-\mathrm{C}$, foi usado na fixação do conjunto composto pela mesa linear e pelo servomotor, além de servir de suporte para a cuba de ensaios. Os demais perfis correspondem à vista B-B, tendo sido construídos conforme a figura 4.37(b) Ambos foram determinados de modo iterativo. 

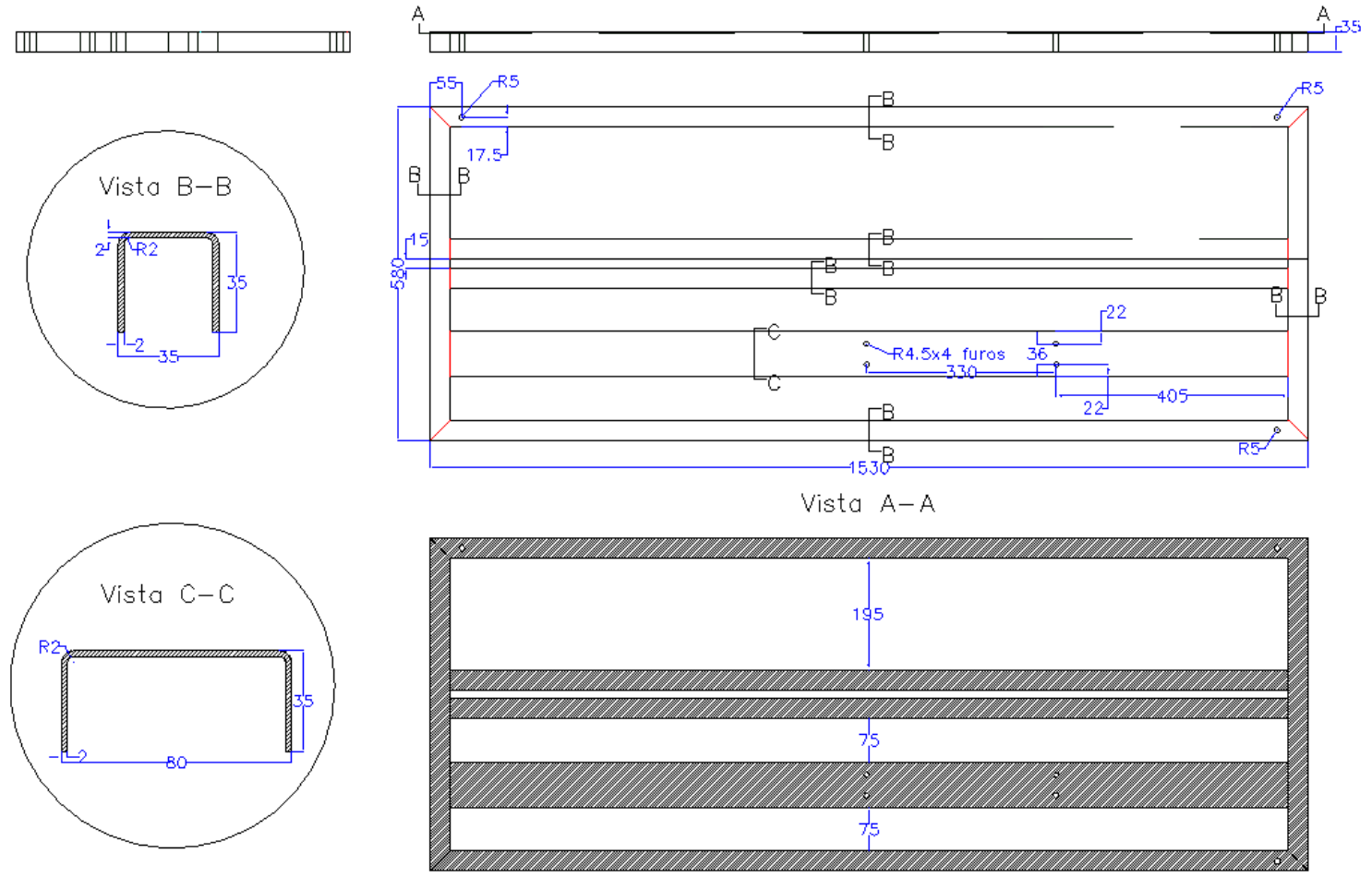

Figura 4.36: Projeto da base, cujo propósito é impedir deslocamentos relativos entre as partes do equipamento.

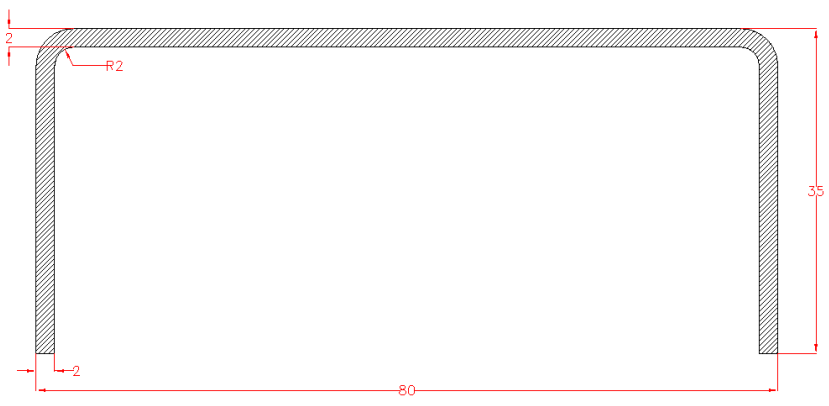

(a) Perfil largo

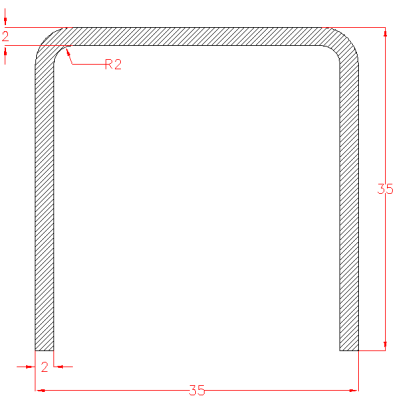

(b) Perfil fino

Figura 4.37: Perfis usados na confecção da base

Conforme mostra a figura 4.38 , a força axial ao espécime exerce momento de $M=$ $F . b=500 \mathrm{~N} .0,12891 \mathrm{~m}=64,455 \mathrm{Nm}$. 


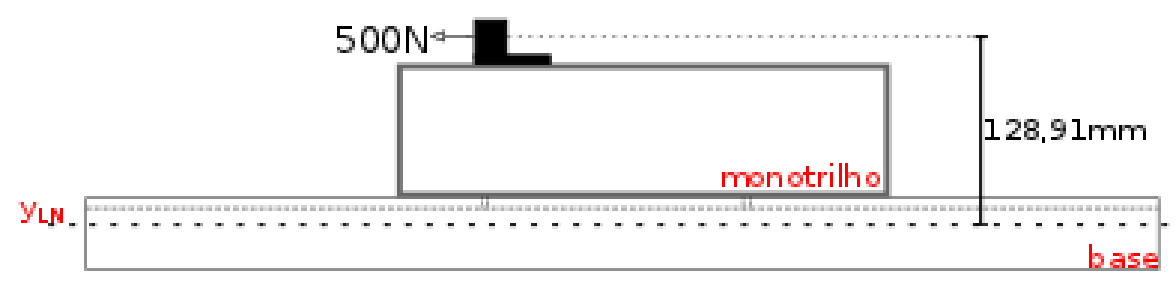

Figura 4.38: Detalhe e vista frontal parcial do perfil mais largo, evidenciando a principal força atuante sobre ele.

A equação (4.2) retorna tensão, devida ao momento fletor máximo atuante, de $\sigma_{M}=$ 49, $199 \mathrm{MPa}$, e a equação (3.5), tensão máxima de $\sigma_{T}=1,712 \mathrm{MPa}$, devida à tração. Assim, a tensão atuante sobre o perfil mais largo totaliza $\sigma=50,911 \mathrm{MPa}$. Dessa forma, o fator de segurança é de $\frac{E}{\sigma}=\frac{210}{50,911}=4,125$.

Fixada à base por meio de duas mãos francesas, a chapa de aço à esquerda da cuba de ensaios contrapõe a força exercida pelo servomotor (figura 4.39). Cada mão francesa foi fixada a um perfil distinto. Dada a simetria do conjunto, assumiu-se que cada uma deveria resistir a uma força de $250 \mathrm{~N}$, sem sofrer deformações plásticas. Sendo o momento máximo $M=F . b=250 \mathrm{~N} .0,13244 \mathrm{~m}=33,11 \mathrm{Nm}$, as tensões geradas no perfil apresentado, por meio das mesmas equações, foram $\sigma_{M}=28,73 \mathrm{MPa}$, $\sigma_{T}=1,237 \mathrm{MPa}$ e $\sigma=29,967 \mathrm{MPa}$, resultando em um fator de segurança de $\frac{E}{\sigma}=$ $\frac{210}{29,967}=7,008$.

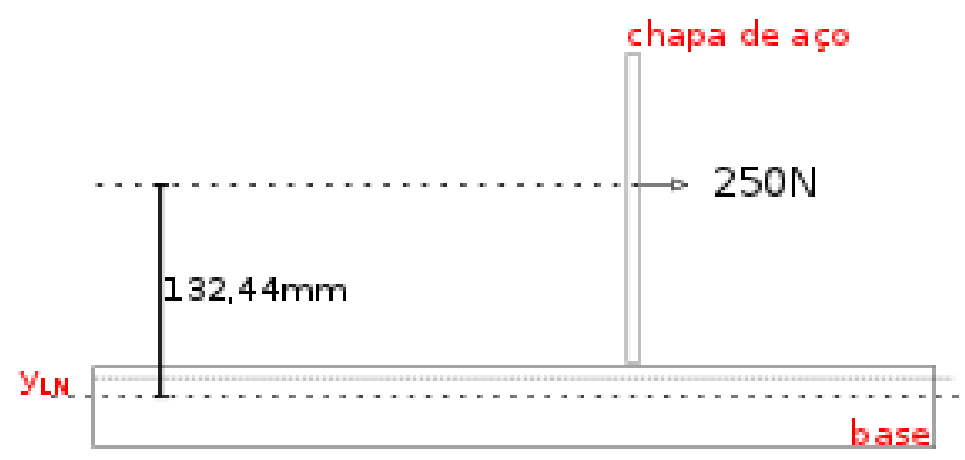

Figura 4.39: Detalhe e vista frontal parcial do perfil mais estreito, evidenciando a principal força atuante sobre ele. 


\subsubsection{Controle e aquisição de dados}

Os testes são controlados por um sistema a malha aberta, com coleta dos dados para futura análise. Para tal, foi usada a placa de aquisição National Instruments, modelo NI USB 6008 (figura 4.40), que conta com duas portas digitais, uma com 8 canais, usados no controle do servodrive, e outra com 4 canais, que recebem o alarme de estabilização da pressão na saída da válvula proporcional. Essa placa conta também com 4 entradas analógicas diferenciais. Duas delas foram usadas, uma na leitura do potencial elétrico proveniente do transdutor de pressão, e outra, na leitura do potencial elétrico proveniente da célula de carga. Uma de suas duas saídas analógicas foi usada para controlar a pressão na saída da válvula proporcional.

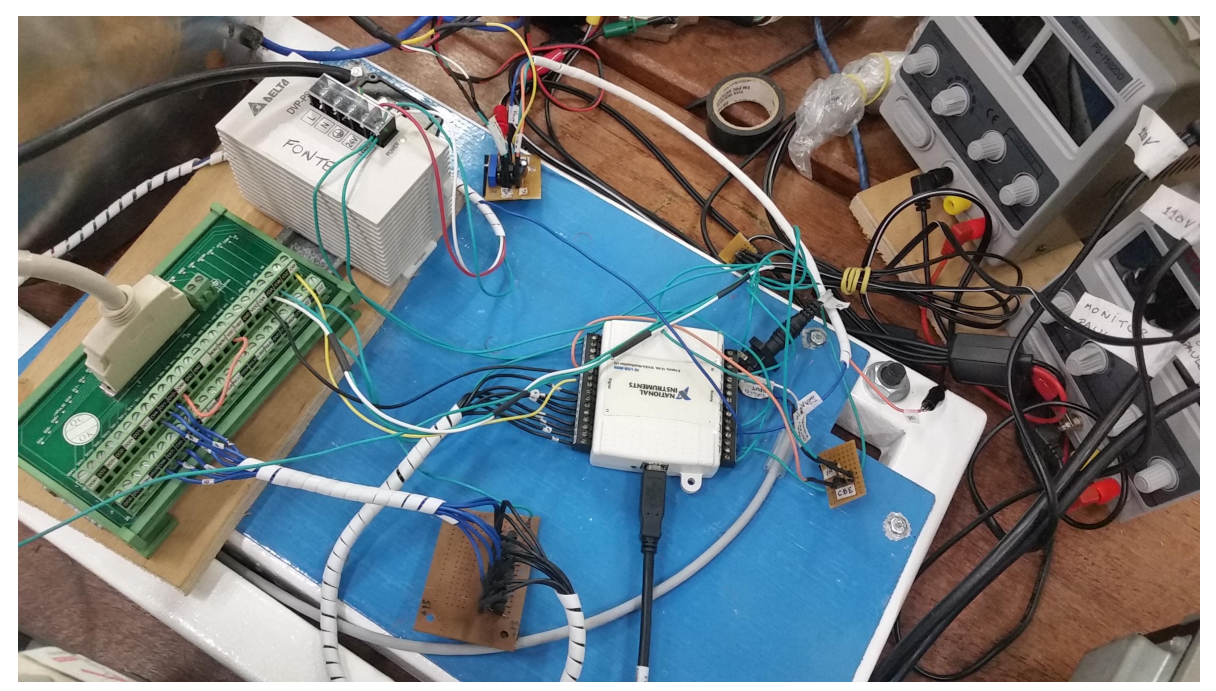

Figura 4.40: Foto da placa de aquisição, marca National Instruments, modelo NI USB 6008.

A cada ensaio foi, inicialmente, medido o sinal da célula de carga, com a cuba cheia, porém sem qualquer espécime, para a obtenção do offset. Em seguida, o espécime podia ser preso à garra, e os testes podiam ter início.

No ensaio de pré-condicionamento do teste de tração, resultados de um dos quais são apresentados na seção 4.4 o primeiro comando mandado para a placa de aquisição, através de linguagem $\mathrm{C}$, foi o sinal binário para o acionamento dos bits do servodrive responsáveis por ligar o servomotor (servo on) e por movimentar o carrinho para a direita, em velocidade pré-definida e ajustável por meio de software próprio ou manualmente, no próprio servodrive. 
O código implementado para o controle do equipamento possibilita o ajuste, pelo usuário, da frequência de amostragem. Como cada comando leva um certo tempo para ser processado pelo computador, o ajuste do tempo de ensaio para os mesmos $15 \mathrm{~s}$ do teste realizado na FMUSP foi obtido iterativamente.

Ao fim dessa tarefa, outro sinal binário foi enviado para a placa de aquisição, para o acionamento dos bits correspondentes ao servo on e ao movimento para a esquerda, na mesma velocidade. O mesmo número de aquisições foi realizado, e a duração desse movimento foi a mesma do primeiro. Ao fim dessa etapa, o primeiro ciclo do pré-condicionamento estava concluído. O processo foi repetido $n$ vezes, sendo $n$, o número de ciclos do pré-condicionamento. A figura 4.41(a) ilustra esse processo, configurável pelo usuário.

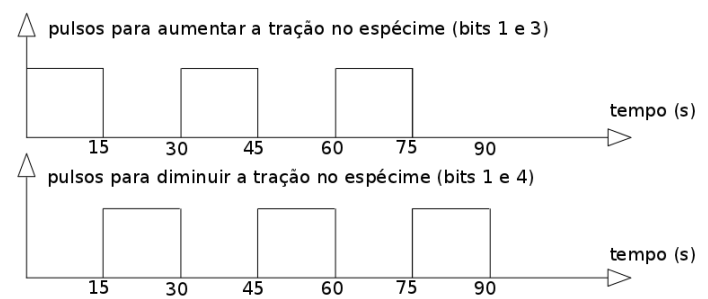

(a) Sinais mandados para o controle da tração longitudinal.

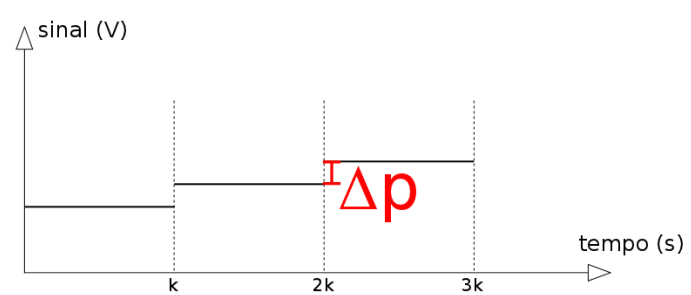

(b) Sinais mandados para o controle do insuflamento.

Figura 4.41: Sinais para os ensaios de pré-condicionamento uniaxiais. Para o ensaio de tração, são mandados sinais digitais, enquanto que, para o de insuflamento, o controle é realizado através de sinais analógicos.

O controle do insuflamento, por sua vez, é realizado através de sinal analógico. Os resultados de um ensaio de pré-condicionamento de insuflamento podem ser apreciados na seção 4.4 .

Nele, o primeiro sinal mandado para a placa de aquisição correspondeu à pressão inicial do ensaio. Em seguida, esperou-se um intervalo de tempo proporcional ao volume, no tanque, preenchido por ar. Feito isso, o sinal passou a receber incrementos fixos em intervalos equiespaçados de tempo. Pouco antes de cada incremento, foi lida a tensão no transdutor de pressão. A espera foi intencional, para que a pressão no interior do tanque e, consequentemente, em sua saída, onde estava o transdutor, estabilizasse. A definição do tempo de espera, nesse ensaio, também foi um processo iterativo, pelo mesmo motivo descrito no teste de tração longitudinal. 
Após o sinal máximo ter sido atingido, esse valor passou a ser decrementado na mesma taxa dos incrementos, e o mesmo número de medidas foi realizado e armazenado, também pouco antes de cada decremento.

Ao se atingir novamente a pressão mínima, tinha-se o primeiro ciclo completo de pré-condicionamento do teste de insuflamento, sendo o tempo de espera, assim como o número de coletas e de ciclos de pré-condicionamento, parâmetros configuráveis pelo usuário. A figura 4.41(b) ilustra esse processo. O incremento de pressão, $\Delta p$, pode ser calculado através da equação (4.10),

$$
\Delta p=\frac{p_{\max }-p_{0}}{k \cdot \frac{t}{k}},
$$

onde $p_{\max }$ denota a pressão máxima do pré-condicionamento, $p_{0}$ denota a pressão de partida, $k$ denota o intervalo entre medições e $t$ denota o tempo, em segundos, de meio ciclo de pré-condicionamento.

Isso é possível porque, conforme mostra a equação (2.2), a relação entre tensão na parede e pressão interna é linear.

Finalizada essa parte do teste, teve início o ensaio de ruptura, em que o aumento dos esforços sobre o espécime foi controlado por sinais conforme as figuras 4.42(a) e 4.42(b), até a falência do espécime.

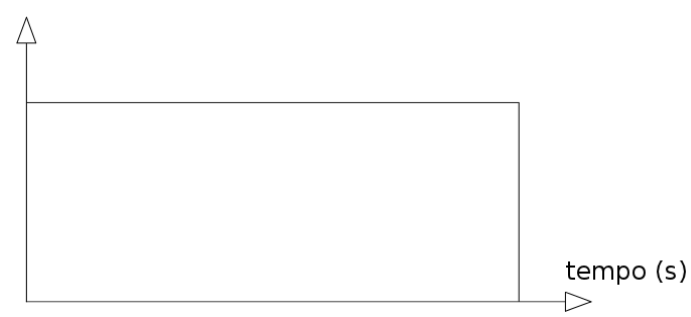

(a) Sinais mandados para o controle da tração longitudinal.

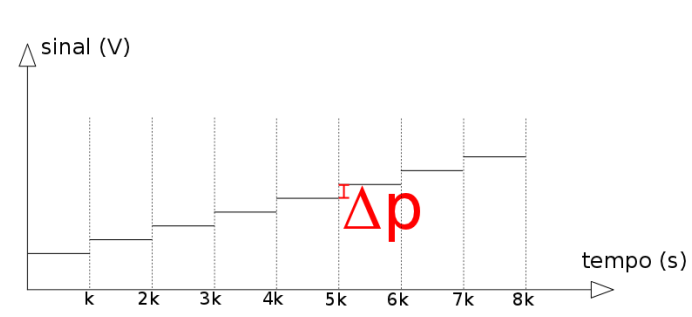

(b) Sinais mandados para o controle do insuflamento.

Figura 4.42: Sinais mandados para os ensaios de ruptura.

O controle do ensaio biaxial foi iniciado pela ativação dos bits correspondentes ao servo on e ao movimento para a direita. Em seguida, em intervalos de tempo pré-estabelecidos, além da aquisição da tensão elétrica proveniente da célula de carga, foi lida a tensão elétrica do transdutor de pressão e, logo após, incrementado o sinal correspondente à pressão interna ao espécime. 
A fim de que se seguisse o padrão adotado nos testes da FMUSP, para os testes de tração com espécimes de $100 \mathrm{~mm}$ de comprimento inicial, era desejável que a deformação máxima, durante o pré-condicionamento, fosse de $5 \mathrm{~mm}$. Para isso, considerando passo de $5 \mathrm{~mm}$ no fuso da mesa deslizante, seria necessária uma revolução completa na saída do redutor, o que equivaleria a trinta e duas voltas do servomotor. Para que isso acontecesse em 15 segundos, configurou-se o servomotor para girar a 128 rotações por minuto. Aortas abdominais de diferentes comprimentos iniciais requererão diferentes configurações, e cada diferente órgão ou tecido requererá um valor também distinto para cada comprimento inicial, a ser determinado pelo Médico especialista requerente.

\subsection{Teste e calibração do equipamento}

A velocidade de rotação do motor é constante, induzindo deslocamento constante da parte móvel da mesa linear, dado por $\Delta S=v . \Delta t$. O desvio-padrão do deslocamento $\left(\sigma_{\Delta S}\right)$ é, portanto, dado pela equação 4.11 ,

$$
\sigma_{\Delta S}=\Delta S \cdot \sqrt{\left(\frac{\sigma_{v}}{\bar{v}}\right)^{2}+\left(\frac{\sigma_{\Delta t}}{\overline{\Delta t}}\right)^{2}}
$$

onde $\bar{v}$ denota a velocidade média, $\sigma_{v}$ denota o desvio-padrão da velocidade, $\bar{\Delta} t$ denota o intervalo médio de tempo e $\sigma_{\Delta t}$ denota o desvio-padrão desses intervalos de tempo.

O resultado encontrado para o desvio-padrão da posição foi de 0,01 mm.

Uma simulação adicional de pré-condicionamento do ensaio de insuflamento foi realizada para a determinação da precisão nas medidas de pressão aquisitadas. As tensões elétricas lidas no transdutor de pressão foram coletadas e plotados com o auxílio do software aberto OpenOffice Calc, conforme a figura 4.43, que apresenta coeficiente de determinação $R^{2} \approx 0,994$, indicação de uma excelente aderência, aos dados apresentados, da regressão linear apresentada na equação (4.12),

$$
y=2,03 x-0.20
$$

onde $a=2,03$ e $b=-0.20$. 
O coeficiente $b$ representa o offset do conjunto, e assume um valor diferente cada vez que o sistema é alimentado.

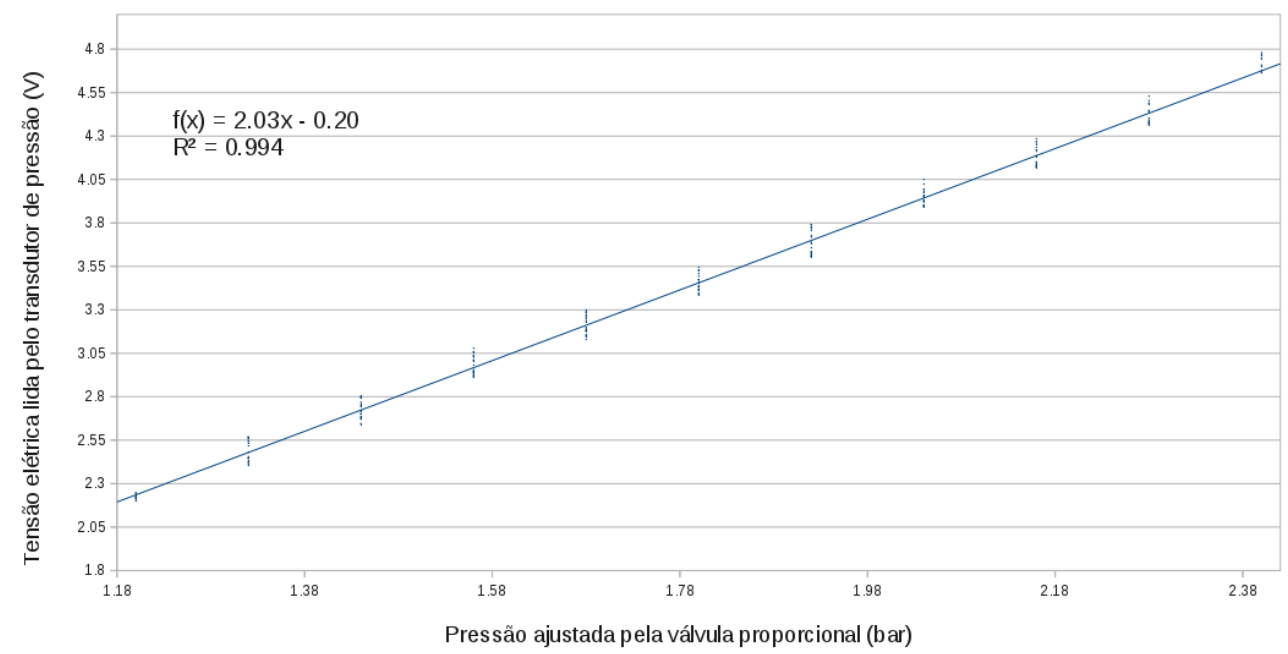

Figura 4.43: Gráfico de dispersão da tensão elétrica (V) lida pelo transdutor de pressão, em função da pressão ajustada pela válvula proporcional reguladora de pressão (bar), para o cálculo da precisão das medidas de pressão aquisitadas.

O desvio-padrão desta coleta ficou em 1,28 kPa.

Adicionalmente, a figura 4.44 mostra o resultado de uma simulação de pré-condicionamento uniaxial de tração, seguindo a frequência dos testes conduzidos no HCFMUSP, descritos na seção 2.4.2. Nesta figura, os segmentos crescentes de reta significam um aumento da tração sobre a estrutura em $U$, portanto, seu movimento para a direita. Adicionalmente, fotos de diferentes instantes de um ensaio desse tipo, com espécime de látex, são mostrados na figura 4.45 . 


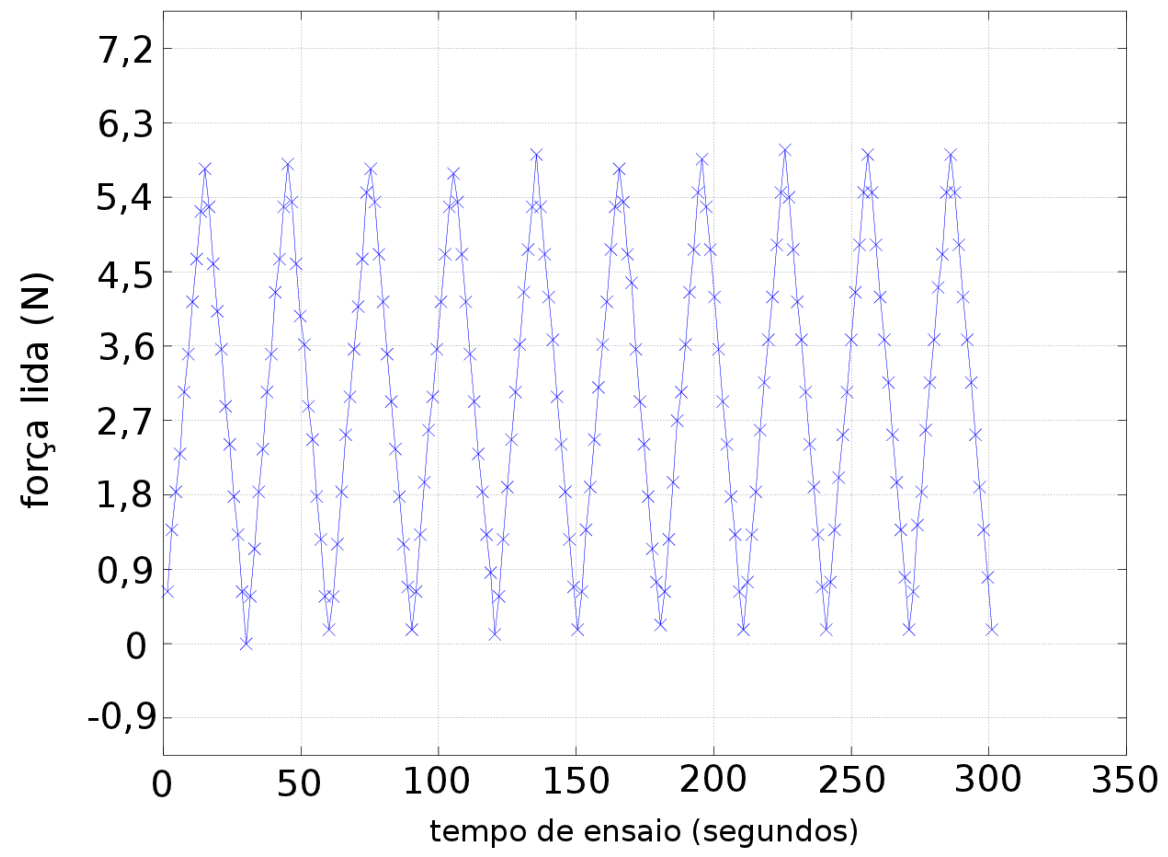

Figura 4.44: Resultado do teste uniaxial de tração, seguindo a frequência dos testes conduzidos na FMUSP. Segmentos crescentes de reta significam aumento de tração sobre a estrutura em $\mathrm{U}$, portanto, seu movimento para a direita.

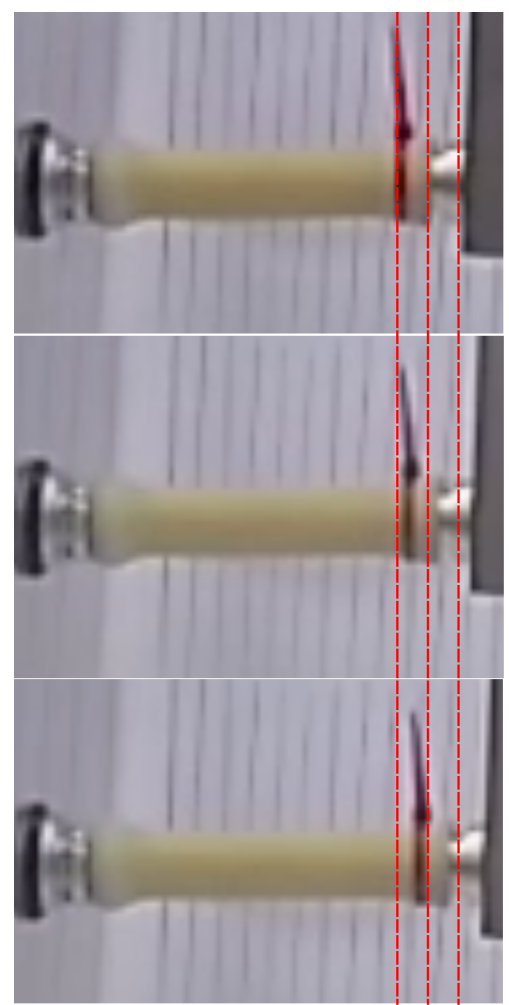

Figura 4.45: Fotos de diferentes instantes do mesmo ensaio de tração com espécime de látex de espessura $3 \mathrm{~mm}$. 
Para a calibração dos resultados de força obtidos, o primeiro passo foi a calibração da célula de carga. Foram realizadas diversas medições com forças conhecidas, com o auxílio de dinamômetros, obtendo-se a dispersão da figura 4.46, que relaciona a tensão lida, em volts, à carga aplicada, em gramas-força. Essa dispersão apresenta coeficiente de determinação $R^{2} \approx 0,972$ e a equação de regressão 4.13 ,

$$
y=2,23.10^{-4} x-3,34
$$

onde $a=2,23 \cdot 10^{-4}$ e $b=-3,34$.

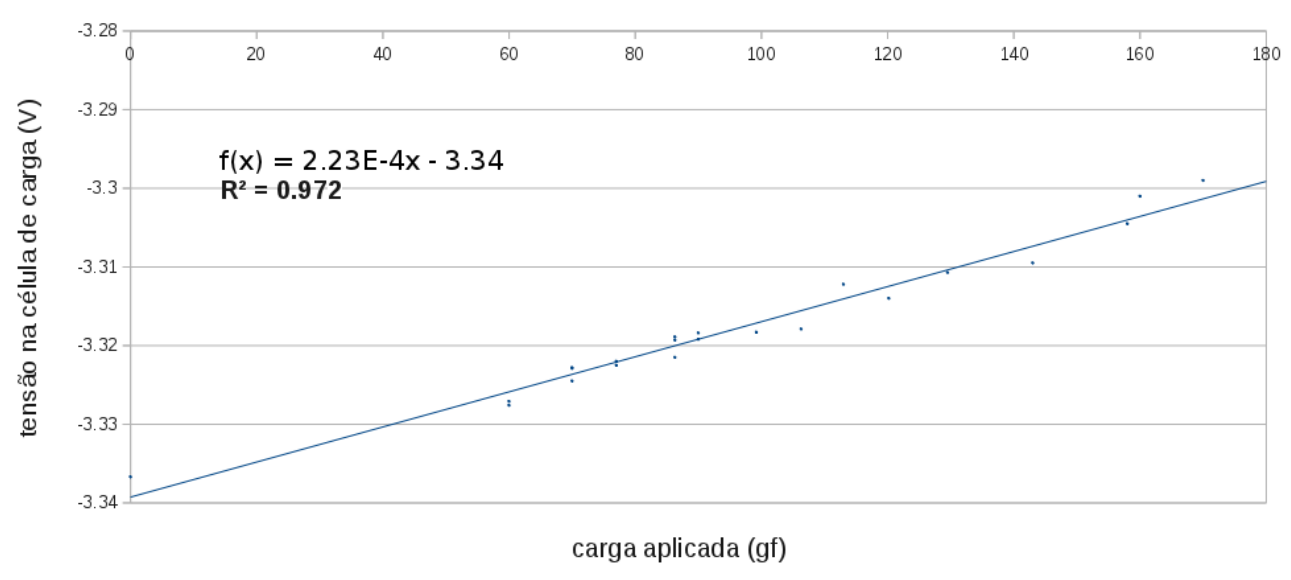

Figura 4.46: Gráfico de dispersão da tensão elétrica (V) coletada pela célula de carga, em função da força aplicada à estrutura em U (gramas-força), para a conversão das medidas.

Mais uma vez, o coeficiente $b$ representa o offset, e assume um valor diferente a cada vez que se alimenta o sistema. Por essa razão, a cada vez que o sistema for alimentado, a primeira coisa a ser realizada pelo operador deverá ser a obtenção dos offsets do transdutor de pressão e da célula de carga, necessariamente com a cuba cheia de água e sem qualquer espécime preso às garras, para que esses valores possam ser subtraídos das leituras.

Feito isso, o próximo passo foi a realização de uma simulação de pré-condicionamento de ensaio de tração com espécime de câmara de pneu de bicicleta, em 10 ciclos com formato de onda triangular, como os da figura 4.44 .

A dispersão da figura 4.47 mostra as leituras da célula de carga apenas nos movimentos da estrutura em $U$ para a esquerda, ou seja, a descida das ondas 
triangulares, sendo essa a razão de a função apresentada ser decrescente. Nessa figura, o primeiro ponto do eixo $x$ representa a primeira das 10 aquisições feitas nessa parte de cada ciclo, ou seja, o ponto de máximo, sendo que cada ponto da dispersão naquele $x$ representa o valor obtido em um ciclo distinto. O mesmo vale para cada um dos aglomerados de pontos em cada $x$ específico do gráfico.

A dispersão resultante apresenta coeficiente de determinação $R^{2} \approx 0,997$, indicação de uma excelente aderência, aos dados apresentados, da regressão linear apresentada na equação (4.14), em que $x$ aparece em gramas-força e $y$, em volts,

$$
y=-0,02 x-3,08
$$

onde $a=-0,02$ e $b=-3,08$.

Aqui, o coeficiente $b$ também assume um valor diferente cada vez que o sistema é alimentado, representando o offset do conjunto. Vale lembrar, novamente, que as análises realizadas para a obtenção dos gráficos 4.46 e 4.47 foram realizadas sem o interrompimento da alimentação do sistema, sendo essa uma condição necessária para o sucesso da aquisição de dados.

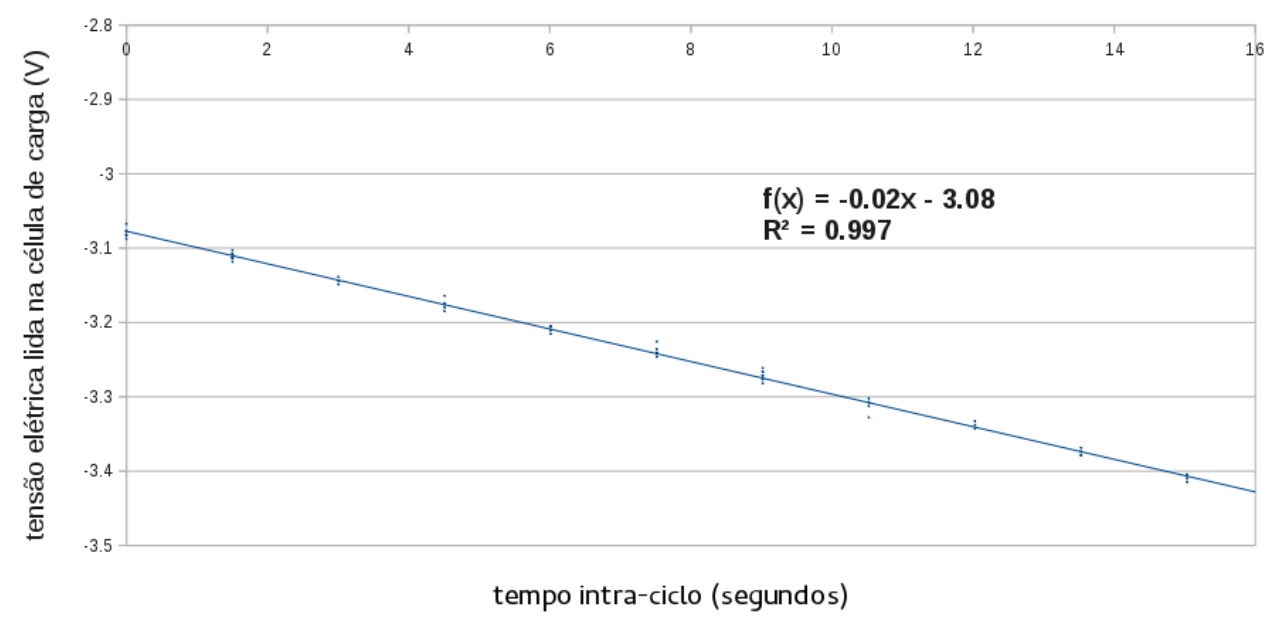

Figura 4.47: Gráfico de dispersão da força aplicada à estrutura em U e dos dados coletados pela célula de carga, em repetidos ciclos de pré-condicionamento, para o cálculo da precisão das medidas de força aquisitadas

O desvio-padrão dos resultados mostrados na figura 4.47 é $3,28.10^{-3} \mathrm{~V}$. De posse desse dado, recorreu-se, novamente, à equação (4.13), para a transformação de volt em 
grama-força. Foi obtido, para o desvio-padrão dessa amostra, o valor de $14,72 g f$, ou $0,15 \mathrm{~N}$.

Conforme calculado na seção 4.3.2. a estrutura em U deforma $5,35.10^{-4} \mathrm{~mm} / \mathrm{N}$, ou seja, são necessários $1869 \mathrm{~N}$ para que a estrutura deforme em $1 \mathrm{~mm}$. Se a força aplicada a esse espécime foi de até $6 \mathrm{~N}$, então a sua deformação foi de $3,21.10^{-3} \mathrm{~mm}$, o que, nesse caso, pode ser desprezado, dado o número de algarismos significativos. De fato, como a célula de carga e os experimentos não passarão de $500 \mathrm{~N}$, o valor máximo de deformação a ser descontado em algum ensaio será de 0,27 mm.

Para uma parte da discussão dos resultados obtidos, diversas simulações de pré-condicionamento de testes uniaxiais de insuflamento foram conduzidas, variando-se apenas as pressões relativas mínima e máxima. Um primeiro resultado, com pressões relativas variando entre 120 e $190 \mathrm{kPa}$, retornou os resultados apresentados na figura 4.48 . A válvula proporcional impôs, nesse caso, incrementos de $7 \mathrm{kPa}$.

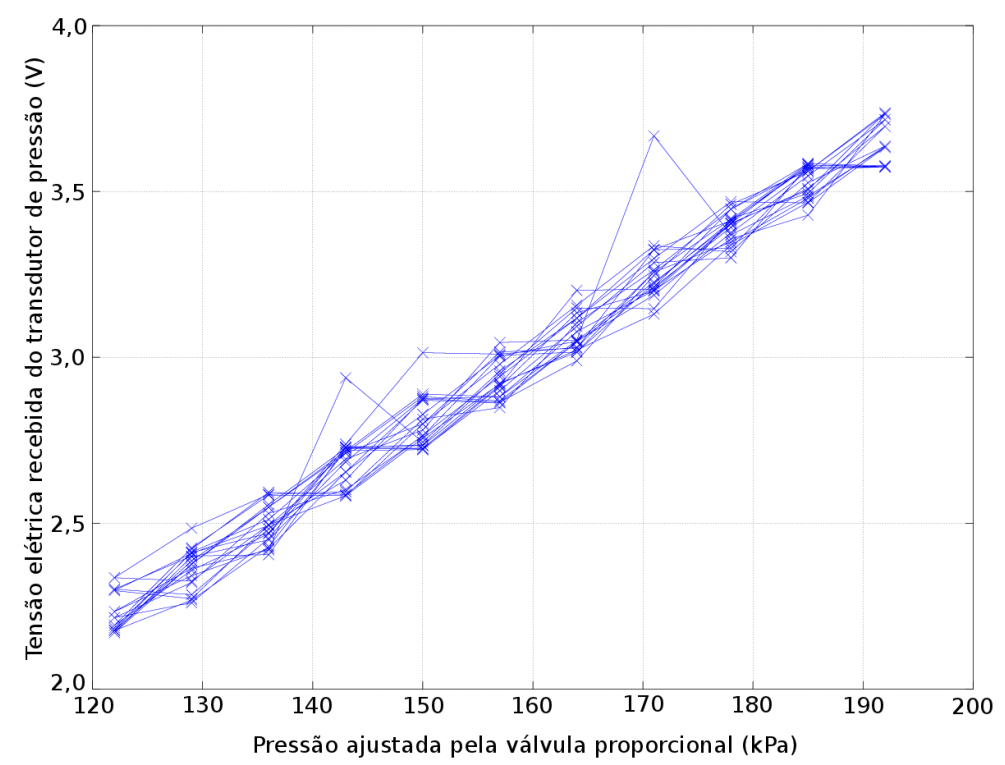

Figura 4.48: Resultado do teste uniaxial de insuflamento com pressão relativa variando entre 120 e $190 \mathrm{kPa}$. A válvula proporcional não teve qualquer dificuldade em impor incrementos de $7 \mathrm{kPa}$.

Levando em conta que, na maior parte dos espécimes a serem estudados através do equipamento desenvolvido, as pressões variariam entre valores muito mais próximos, outros testes foram conduzidos. Dois deles são apresentados nas figuras 4.49 e 4.50 , com incrementos de $3 \mathrm{kPa}$ e $2 \mathrm{kPa}$, respectivamente. 


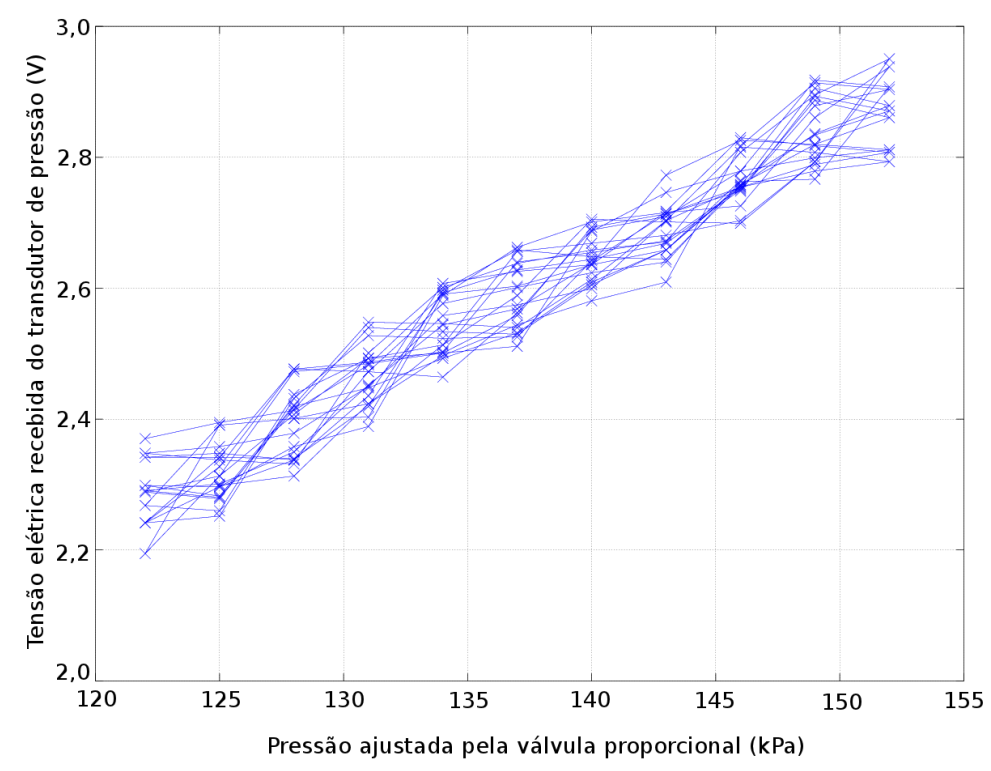

Figura 4.49: Resultado do teste uniaxial de insuflamento com pressão relativa variando entre 120 e $150 \mathrm{kPa}$. A válvula proporcional não teve qualquer dificuldade em impor incrementos de $3 \mathrm{kPa}$.

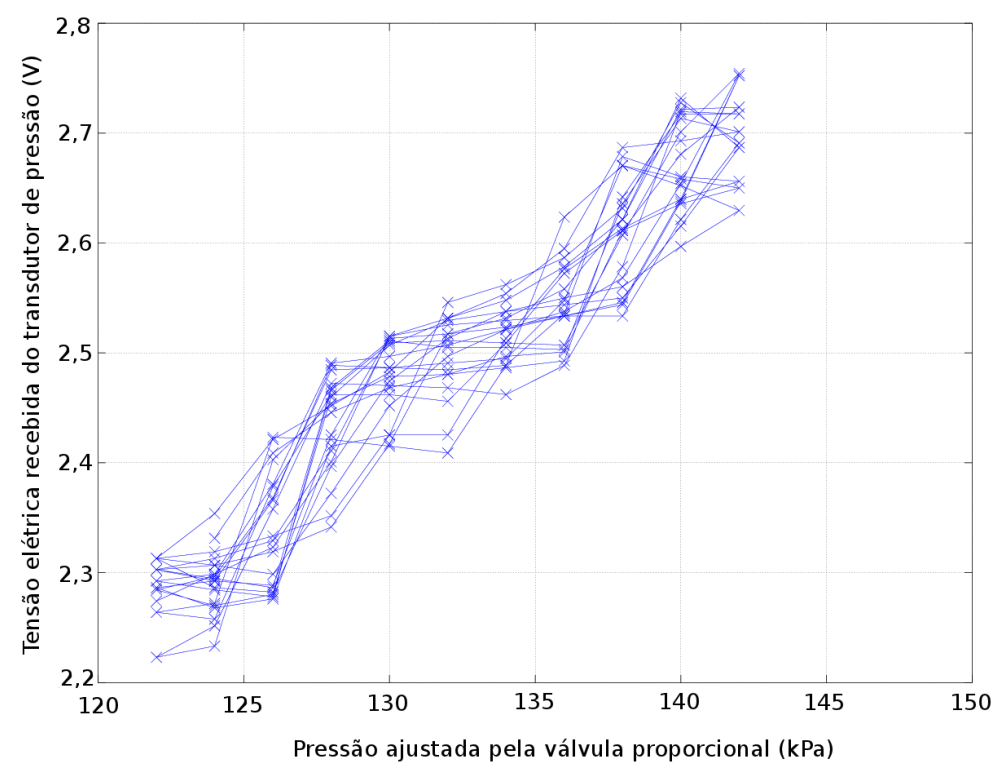

Figura 4.50: Resultado do teste uniaxial de insuflamento com pressão relativa variando entre 120 e $140 \mathrm{kPa}$. A válvula proporcional não se mostrou eficaz na imposição de incrementos de $2 \mathrm{kPa}$.

Foi observado que a válvula usada possuía uma limitação na imposição de incrementos menores, fato mais facilmente observável na figura 4.51. que mostra um teste entre os mesmos extremos da figura 4.50, desta vez, com 1 ciclo de 
pré-condicionamento apenas. Foram evidenciados, em vermelho, os patamares decorrentes dessa limitação, contornável através da troca desta por outra válvula de fundo de escala menor ou de maior resolução.

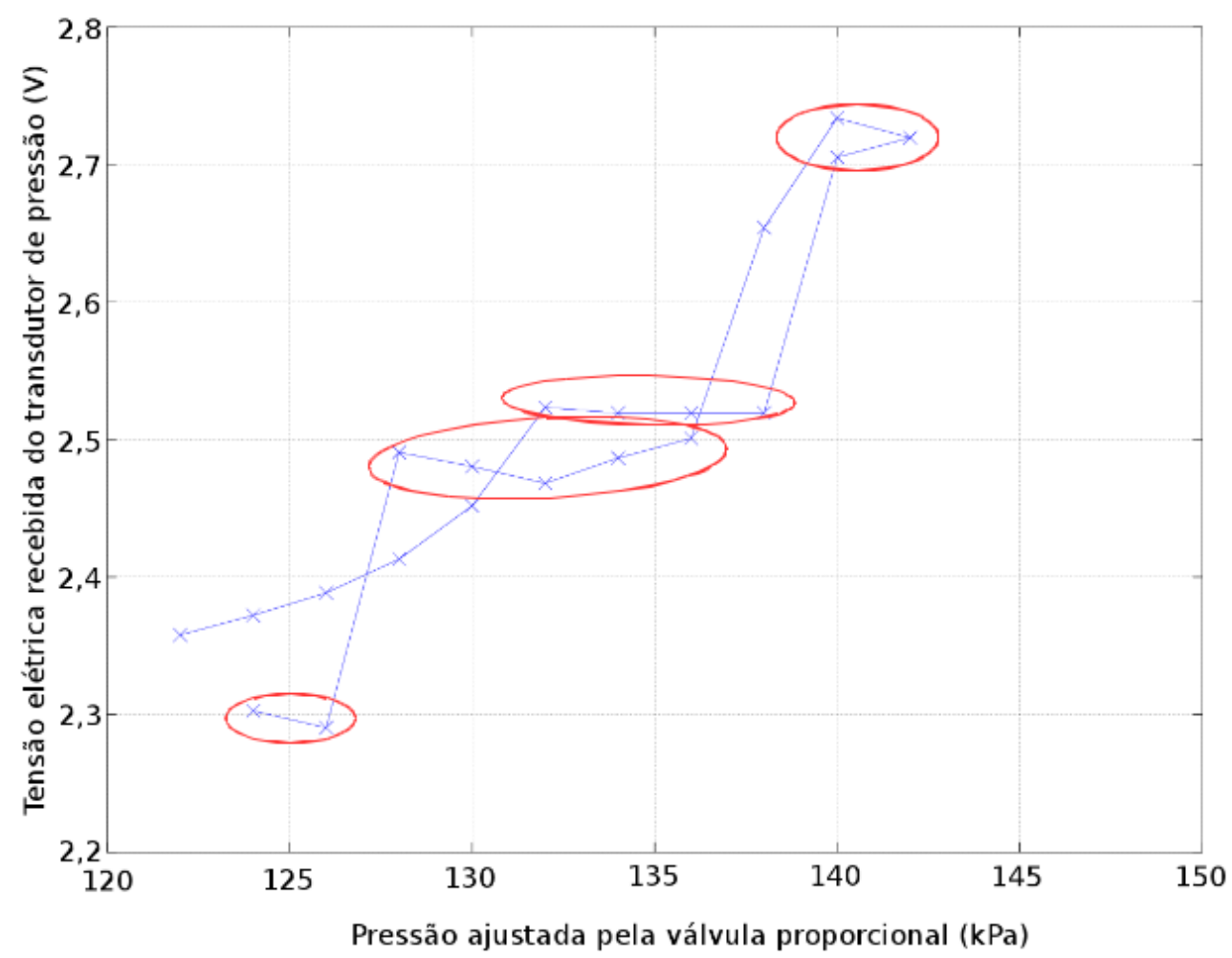

Figura 4.51: Resultado obtido com 1 ciclo de pré-condicionamento uniaxial de insuflamento entre 120 e $140 \mathrm{kPa}$. Em vermelho, ficam evidenciados os patamares decorrentes da limitação da válvula utilizada.

Outra consideração importante sobre os resultados obtidos inclui a interação entre a pressão interna ao espécime e o resultado do teste de tração.

A pressão interna ao espécime exerce, sobre a estrutura em $U$, força compressora, na mesma direção e em sentido contrário da força resistiva de tração exercida pelo espécime, à elongação imposta pelo servomotor. A figura 4.52 mostra, para um teste uniaxial de pré-condicionamento de insuflamento, com 3 ciclos, os registros do transdutor de pressão e da célula de carga, desta vez, em função do tempo. Pode-se observar que, à medida em que a pressão interna ao espécime aumenta, a força registrada pela célula de carga diminui proporcionalmente. 

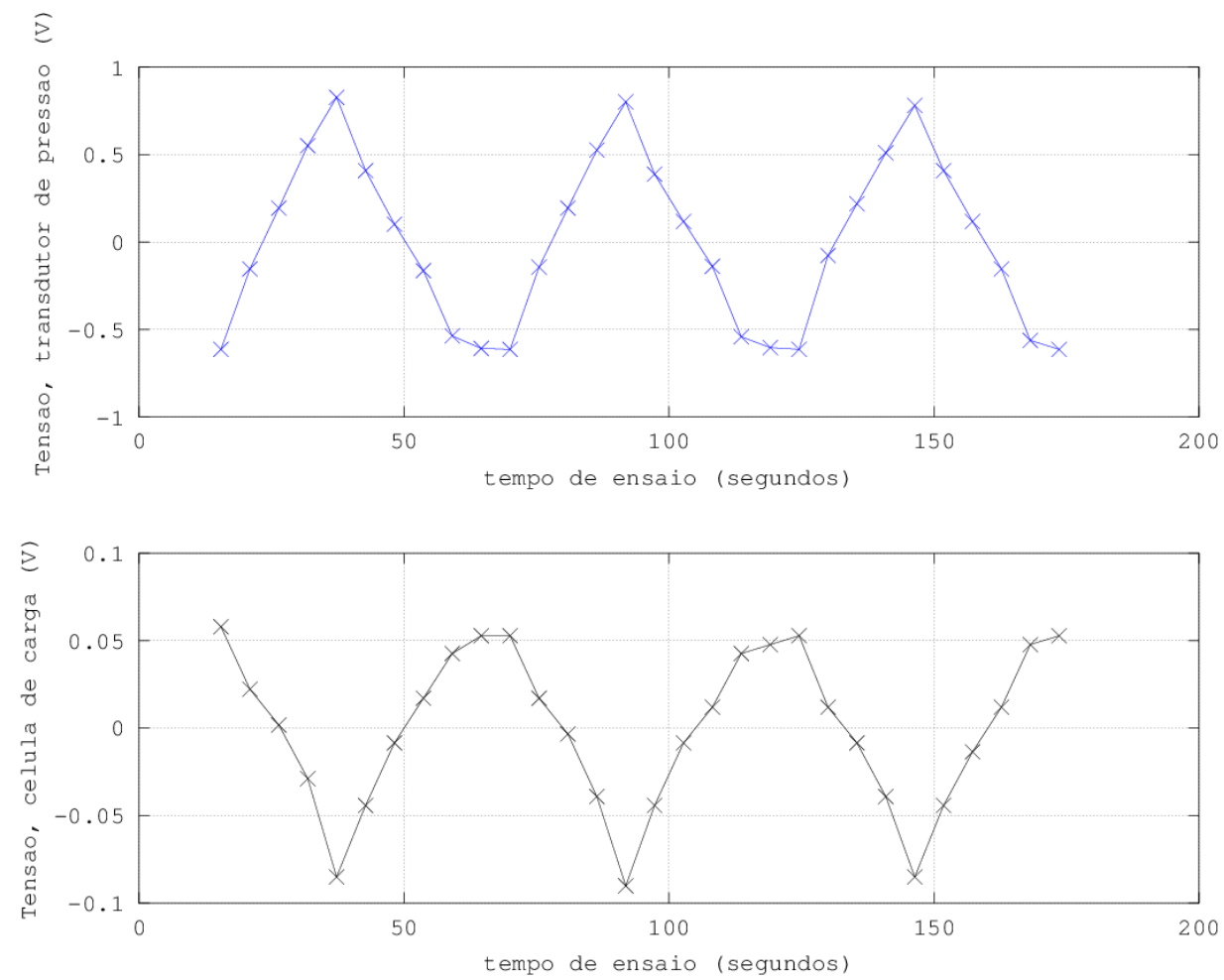

Figura 4.52: Resultado de teste uniaxial de insuflamento com 3 ciclos de pré-condicionamento. O primeiro gráfico mostra os registros do transdutor de pressão e, o segundo, os da célula de carga, ambos em função do tempo. Conforme a pressão no espécime aumenta, a força de tração sobre a estrutura em U diminui proporcionalmente.

Finalmente, a figura 4.53 apresenta o resultado obtido em uma simulação de pré-condicionamento com 10 ciclos. Uma potencial complicação durante os experimentos será o deslizamento dos espécimes na região das garras, mais uma potencial fonte de erro, destacada, em vermelho, na mesma figura. Nota-se que os pontos de mínimo, nesses ciclos, estão ligeiramente abaixo dos pontos de mínimo dos ciclos anteriores, e que, em cada um dos grupos, evidenciados e não evidenciados, o valor médio desses pontos, bem como dos outros pontos de cada grupo de ciclos, tende a se manter aproximadamente constante. A filmagem dos testes, aliada à marcação do espécime, pode ser eficaz para a observação desse movimento relativo. 

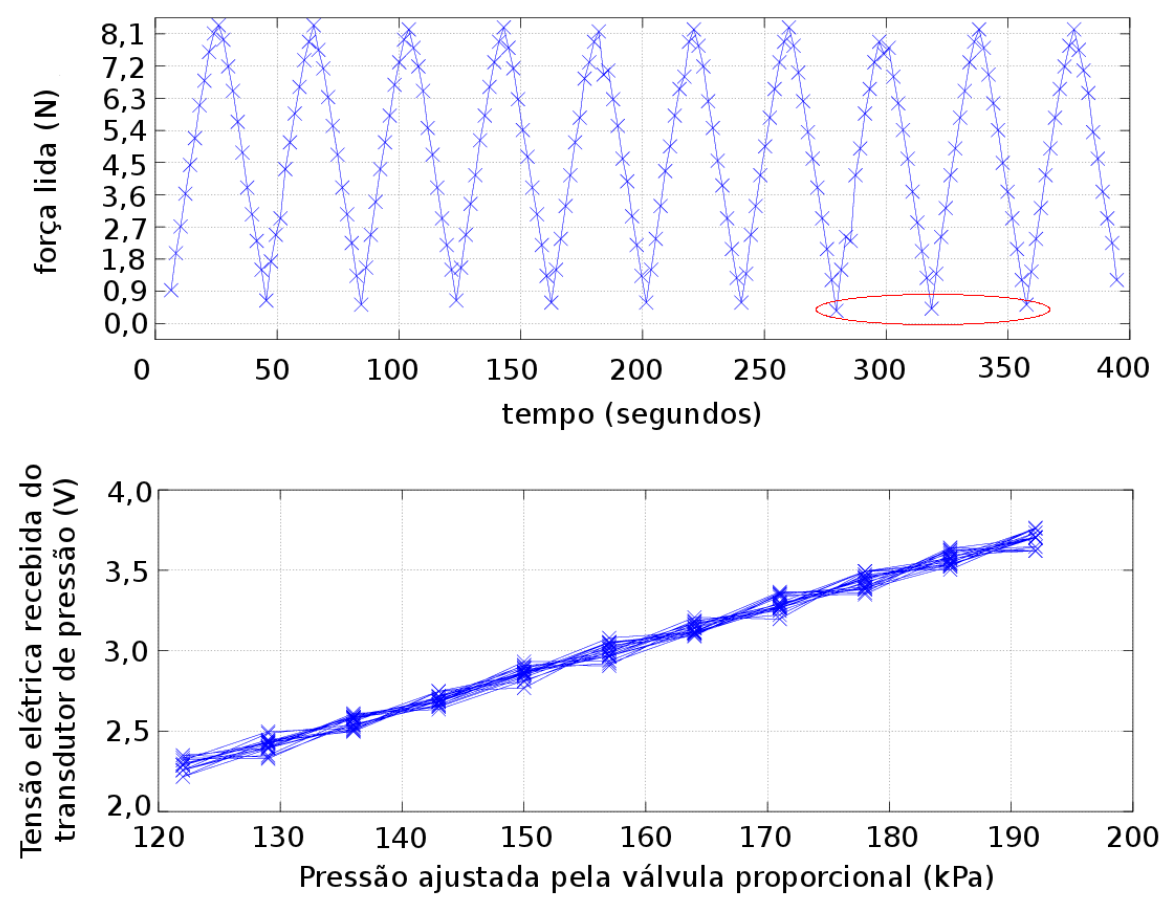

Figura 4.53: Resultado de ensaio biaxial, evidenciando um possível escorregamento do espécime em relação à garra.

Muitos testes foram conduzidos, variando-se, dentre outros, a espessura e a ductilidade da membrana testada, assim como o método de fixação. Linhas de sutura não se mostraram eficazes na fixação de espécimes de maior espessura ou ductilidade. Nesses casos, foram utilizados lacres plásticos. A figura 4.54 mostra 5 diferentes instantes de um teste biaxial de espécime de látex de espessura $3 \mathrm{~mm}$, invalidado por ter se soltado da garra na extremidade esquerda, em que foi usada linha de sutura. $\mathrm{Na}$ extremidade direita, por sua vez, o lacre plástico foi suficiente para resistir aos esforços impostos. 


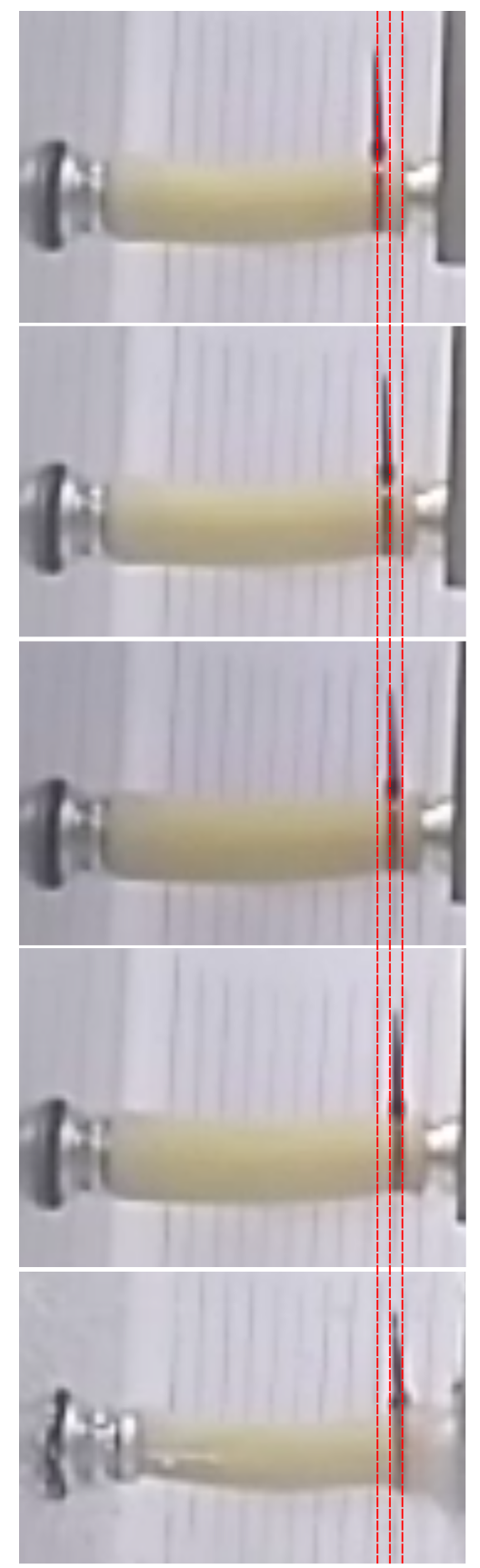

Figura 4.54: Fotos de diferentes instantes do ensaio biaxial com espécime de espessura $3 \mathrm{~mm}$. A última foto mostra o instante em que o espécime se solta da garra, evidenciando a baixa eficácia, no caso de espécimes de espessura maior (no caso, $3 \mathrm{~mm}$ ), do uso de linhas de sutura (extremidade esquerda), comparado a lacres plásticos (extremidade direita).

A figura 4.55 mostra diferentes instantes de um teste bem sucedido de ruptura biaxial, conduzido com câmara de pneu de bicicleta, de espessura $1 \mathrm{~mm}$. Ambas as extremidades foram presas com lacres plásticos. 


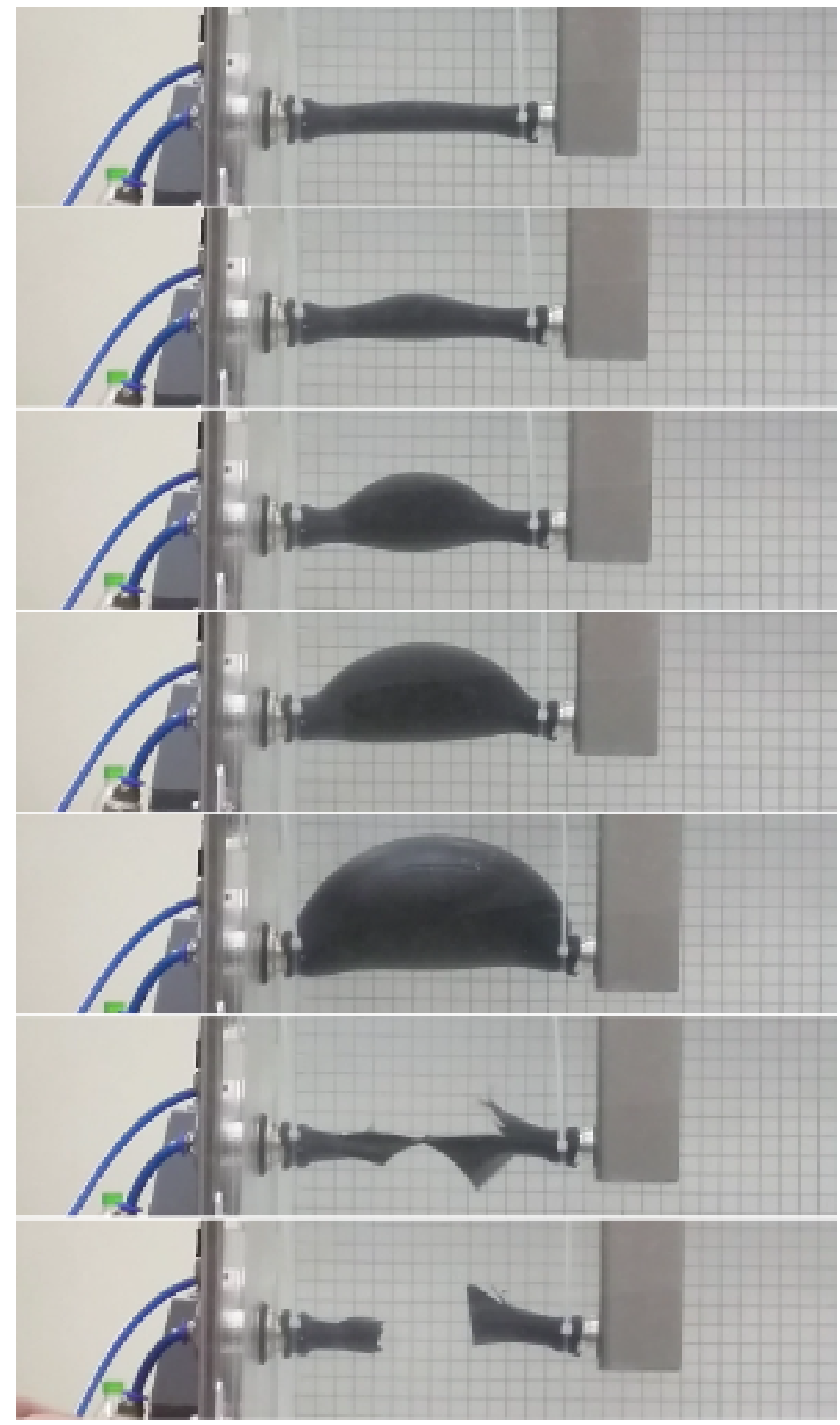

Figura 4.55: Fotos de diferentes instantes de ensaio biaxial bem sucedido com câmara de pneu de bicicleta, de espessura $1 \mathrm{~mm}$. Extremidades presas com lacres plásticos.

Finalmente, deve-se ressaltar que, além da troca da válvula proporcional reguladora de pressão em ensaios cujos extremos sejam próximos, novas garras deverão ser projetadas e construídas, conforme a necessidade surgir, durante os testes de diferentes tipos de tecido com o equipamento apresentado. 


\section{Capítulo 5}

\section{Conclusão}

Escolhidos os tecidos a serem caracterizados, os parâmetros físicos necessários ao equipamento foram estimados, permitindo seu projeto e construção. Testes de pré-condicionamento cíclico em ondas triangulares retornaram dados com forte aderência. O intervalo de erro dos dados de pressão aquisitados foi de $169,92 \pm 1,28 \mathrm{kPa}$. Para os de posição, o intervalo de erro foi de 10,02 $\pm 0,01 \mathrm{~mm} \mathrm{e}$, para os de força, de $5,14 \pm 0,15 \mathrm{~N}$. Em trabalhos futuros, recomenda-se a troca da válvula proporcional, para melhorar a precisão de ajuste em ensaios com pequenas variações de pressão, como a maioria dos tecidos biológicos analisados neste trabalho. 


\section{Referências Bibliográficas}

[1] Dr. José Augusto Tavares Monteiro. Estudo das propriedades histológicas e biomecânicas de fragmentos da parede anterior de aneurismas da aorta abdominal. Tese de doutorado, Faculdade de Medicina da Universidade de São Paulo, São Paulo, Brasil, 2013.

[2] R. C. Darling, C. R. Messina, D. C. Brewster, and L. W. Ottinger. Autopsy study of unoperated abdominal aortic aneurysms. the case for early resection. Circulation, 56:161-164, 1977.

[3] A. V. Sterpetti, R. D. Schultz, R. J. Feldhaus, S. E. Cheng, and Jr D. J. Peetz. Factors influencing enlargementrate of small abdominal aortic aneurysms. Journal of Surgical Research, 43:211-219, 1987.

[4] M. L. Raghavan, J. Kratzberg, E. M. C de Tolosa, M. M. Hanaoka, P. Walker, and E. S. da Silva. Regional distribution of wall thickness and failure properties of human abdominal aortic aneurysm. Journal of Biomechanics, 39:3010-3016, 2006.

[5] D. A. Vorp. Biomechanics of abdominal aortic aneurysm. Journal of Biomechanics, 40:1887-1902, 2007.

[6] Ana Isabel Arroyave Guzmán. Metodologia para caracterização mecânica de tecido biológico mole. Dissertação de mestrado, Escola Politécnica da Universidade de São Paulo, São Paulo, Brasil, 2014.

[7] H. Haimovici. Vascular Surgery: Principles and techniques, 2nd edition. 1984.

[8] D. G. Hepworth, A. Steven-fountain, D. M. Bruce, and J.F.V. Vincent. Affine versus non-affine deformation in soft biological tissues, measured by the reorientation and stretching of collagen fibres through the thickness of compressed porcine skin. Journal of Biomechanics, 34:341-346, 2001.

[9] C. A. J. Schulze-Bauer, P. Regitnig, and G. A. Holzapfel. Mechanics of the human femoral adventitia including the high-pressure response. American Journal of Physiology: Heart and Circulatory Physiology, 282:2427-2440, Janeiro 2002.

[10] Erasmo Simão da Silva. Variações do diâmetro da aorta abdominal infra-renal. Análise crítica baseada em estudo necroscópico. Tese de doutorado, Faculdade de Medicina da Universidade de São Paulo, São Paulo, Brasil, 1996.

[11] E. Di Martino, A. Bohra, J. P. V. Geest, N. Gupta, M. S. Makaroun, and D. A. Vorp. Biomechanical properties of ruptured versus electively repaired abdominal aortic aneurysm wall tissue. Journal of Vascular Surgery, 43:570-576, Março 2006. 
[12] M. Carmo, L. Colombo, A. Bruno, F. R. M. Corsi, L. Roncoroni, M. S. Cuttin, F. Radice, E. Mussini, and P. G. Settembrini. Alteration of elastin, collagen and their cross-links in abdominal aortic aneurysms. European Journal of Vascular and Endovascular Surgery, 23:543-549, 2002.

[13] N. Sakalihasan, A. Heyeres, B. V. Nusgens, R. Limet, and C. M. Lapière. Modifications of the extracellular matrix of aneurysmal abdominal aortas as a function of their size. European Journal of Vascular Surgery, 7:633-637, 1993.

[14] E. Di Martino, S. Mantero, F. Inzoli, G. Melissano, D. Astore, and R. Chiesa. Biomechanics of abdominal aortic aneurysm in the presence of endoluminal thrombus: experimental caracterization and structural static computational analysis. European Journal of Vascular and Endovascular Surgery, 15:290-299, 1998.

[15] M. L. Raghavan, M. W. Webster, and D. A. Vorp. Ex vivo biomechanical behavior of abdominal aortic aneurysm- assessment using a new mathematical modeling. Annals of Biomedical Engineering, 24:573-582, 1996.

[16] J. Xiong, S. Ming Wang, W. Zhou, and J. Gou Wu. Measurement and analysis of ultimate mechanical properties, stress-strain curve fit, and elastic modulus formula of human abdominal aortic aneurysm and nonaneurysmal abdominal aorta. Journal of Vascular Surgery, 48, Julho 2008.

[17] C. M. He and M. R. Roach. The composition and mechanical properties of abdominal aortic aneurysm. Journal of Vascular Surgery, 20:6-13, Julho 1994.

[18] B. Sonesson, T. Länne, E. Vernersson, and F. Hansen. Sex difference in the mechanical properties of the abdominal aorta in human beings. Journal of Vascular Surgery, 20(3), 1994.

[19] T. Lanne, B. Sonesson, D. Bergqvist, H. Bengtsson, and D. Gustafsson. Diameter and compliance in the male human abdominal aorta: influence of age and aortic aneurysm. European Journal of Vascular Surgery, 6:178-184, 1992.

[20] I. J. Hoogendam, A. C. Van Rinsum, and J. Olyslager. The diameter of the distal abdominal aorta and the aetiology of local atheroma. Journal of Cardiovascular Surgery, 25:408-413, 1984.

[21] J. F. Blanchard, H. K. Armenian, and P. P. Friesen. Risk factors for abdominal aortic aneurysm: Results of a case-control study. American Journal of Epidemiology, 151, 2000.

[22] N. Diehm, F. Dick, T. Schaffner, J. Schmidli, C. Kalka, S. Di Santo, J. Voelzmann, and I. Baumgartner. Novel insight into the pathobiology of aaa and potential future treatment concepts. Progress in Cardiovascular Diseases, 50:209-17, 2007.

[23] M. M. Dua and Ronald L. Dalman. Hemodynamic influences on abdominal aortic aneurysm disease: Application of biomechanics to aneurysm pathophysiology. Vascular Pharmacology, 53:11-21, 2010.

[24] R. M. Sandford, M.J. Bown, N.J. London, and R.D. Sayers. The genetic basis of aaa: A review. European Journal of Vascular and Endovascular Surgery, 33:381-90, 2007. 
[25] J. T. Powell and R. M. Greenhalgh. Multifactorial inheritance of aaa. European Journal of Vascular Surgery, 1:29-31, Fevereiro 1987.

[26] H. Bengtsson, B. Sonesson, and D. Bergqvist. Incidence and prevalence of abdominal aortic aneurysms, estimated by necropsy studies and population screening by ultrasound. Annals of the New York Academy of Sciences, 800:1-24, 1996.

[27] Dr. Erasmo Simão da Silva. Personal communication, Novembro 2014.

[28] F. P. Beer and Jr E. R. Johnston. Resistência dos materiais, terceira edição. 1989.

[29] Dr. José Augusto Tavares Monteiro. Personal communication, 2012.

[30] Pedro Carlos da Silva Telles. Vasos de Pressão, segunda edição. 1996.

[31] N. Reuge, F. M. Schmidt, Y. Le Maoult, M. Rachik, and F. Abbé. Elastomer biaxial characterization using bubble inflation technique. i- experimental investigations. Polymer Engineering and Science, 41, Março 2001.

[32] C. M. Garcia-Herrera, J. M. Atienza, F. J. Rojo, E. Claes, G. V. Guinea, D. J. Celentano, C. Garcia-Montero, and R. L. Burgos. Mechanical behaviour and rupture of normal and pathological human ascending aortic wall. Medical and Biological Engineering and Computing, 50:559-566, 2012.

[33] Egor Paul Popov. Introdução à mecânica dos sólidos. 2005.

[34] Edir Branzoni Leal. Simulador hidrodinâmico para estudos "in vitro"do sistema cardiovascular. Dissertação de mestrado, Escola Politécnica da Universidade de São Paulo, São Paulo, Brasil, 2001.

[35] J. Sobotta, R. Pabst, and R. Putz. Sobotta: atlas de anatomia humana, 21a edição. 2000.

[36] J. Black and G. Hastings. Handbook of Biomaterial Properties. 1998.

[37] F. R. Escobar and P.A. Bertran. Incontinencia urinaria post-prostatectomía. el esfincter artificial. Archivos españoles de urología, 62:838-844, 2009.

[38] Dr. Paulo Rodrigues. Personal communication, 2013.

[39] B. Kuo and D. Urma. Esophagus - anatomy and development. GI Motility Online, 2006.

[40] C. Bellini, P. Glass, M. Sitti, and E. Martino. Biaxial mechanical modeling of the small intestine. Journal of Mechanical Behavior of Biomedical Materials, 4:1727-1740, 2011.

[41] D. Mohan and J. Melvin. Failure properties of passive human aortic tissue. i uniaxial tension tests. Journal of Biomechanics, 15:887-902, Junho 1982.

[42] M. Zemánek, J. Bursa, and M. Deták. Biaxial tension tests with soft tissue of arterial wall. Engineering Mechanics, 16:3-11, 2009. 
[43] C. Goergen, B. Johnson, J. Greve, C. Taylor, and C. Zarins. Increased anterior abdominal aortic wall motion: possible role in aneurysm pathogenesis and design of endovascular devices. Journal of Endovascular Therapy, 14:574-584, 2007.

[44] W. Stooker, M. Gök, P. Sipkema, H. Niessen, A. Baidoshvili, N. Westerhof, E. Jansen, C. Wildevuur, and L. Eijsman. Pressure-diameter relationship in the human greater saphenous vein. The Annals of Thoracic Surgery, 76:1533-1538, 2003.

[45] U. Patel. Imaging and urodynamics of the lower urinary tract, second edition. 2010.

[46] V. Egorov, I. Schastlivtsev, E. Prut, A. Baranov, and R. Turusov. Mechanical properties of the human gastrointestinal tract. Journal of Biomechanics, 35:1417-1425, 2002.

[47] G. B. Johnson and P. Raven. Biology: Visualizing Life. 1994.

[48] Gustav Niemann. Elementos de máquinas, sétima reimpressão, volume 1. 1971.

[49] A. E. B. Antunes and L. M. D. Antunes. Comportamento plástico do aço inoxidável austenítico em baixa temperatura. Revista Escola de Minas, 60, 2006. 